\title{
Saccharomyces cerevisiae EM MILHO ARMAZENADO E O EFEITO NA REDUÇÃO DE AFLATOXICOSES
}

\section{ANTONIO SAMPAIO BAPTISTA}

Dissertação apresentada à Escola Superior
de Agricultura "Luiz de Queiroz",
Universidade de São Paulo, para
obtenção do título de Mestre em
Agronomia, Área de Concentração:
Microbiologia Agrícola.

P I R A C I C A B A

Estado de São Paulo - Brasil

Março - 2001 


\title{
Saccharomyces cerevisiae EM MILHO ARMAZENADO E O EFEITO NA REDUÇÃO DE AFLATOXICOSES
}

\author{
ANTONIO SAMPAIO BAPTISTA \\ Engenheiro A grônomo
}

Orientador: Prof. Dr. JORGE HORII

\begin{abstract}
Dissertação apresentada à Escola Superior de Agricultura "Luiz de Queiroz", Universidade de São Paulo, para obtenção do título de Mestre em Agronomia, Área de Concentração: Microbiologia A grícola.
\end{abstract}

P I R A C I C A B A

Estado de São Paulo - Brasil

Março - 2001 
Dados Internacionais de Catalogação na Publicação (CIP)

DIVISÃO DE BIBLIOTECA E DOCUMENTAÇÃ̃O - Campus "Luiz de Queiroz"/USP

Baptista, Antonio Sampaio
Saccharomyces cerevisiae em milho armazenado e o efeito na redução de aflatoxicoses/ Antonio Sampaio Baptista. - - Piracicaba, 2001.

94p. : il.

Dissertação (mestrado) - - Escola Superior de Agricultura Luiz de Queiroz, 2001.

Bibliografia.

1.Aflatoxina 2. Célula microbiana 3.Cultura de Célula 4. Levedura 5. Milho armazenado I. Título

CDD 589..23

"Permitida a cópia total ou parcial deste documento, desde que citada a fonte - $\mathrm{O}$ autor" 


\section{AO MEU IRMÃO}

Aparecido Sampaio Baptista

\section{E ÀS MINHAS IRMÃS}

Ângela Maria Sampaio Baptista e

Ana Angelita Sampaio Baptista

\section{OFEREÇO}

\section{AOS MEUS PAIS}

Jorge Alcântara Baptista e

Tereza Sampaio Baptista 
"Ainda que eu fale as línguas dos homens e dos anjos, se não tiver amor, serei como o bronze que soa, ou como címbalo que retine"

(Drummond, H. - O Dom Supremo) 


\section{AGRADECIMENTOS}

Poucas tarefas são tão agradáveis como o reconhecimento de minha gratidão a todos que colaboraram neste esforço de modo tão diferentes. Entre estes quero agradecer:

A Deus, pela vida e por tantas vitórias;

À Escola Superior de Agricultura "Luiz de Queiroz" da Universidade de São Paulo, por me proporcionar a oportunidade de utilizar a infra-estrutura básica para o desenvovlimento deste projeto;

À CAPES pelo auxílio financeiro indispensável à realização desta pesquisa;

Ao Prof. Dr. Jorge Horii pela oportunidade de realizar este estudo, orientação, convivência, amizade e confiança demonstrada;

À Prof ${ }^{\mathrm{a}}$. Dr ${ }^{\mathrm{a}}$. Marília Oetterer pela sua influência na minha formação profissional e pela perspicácia, críticas e sugestões tão úteis neste trabalho;

Ao Prof. Dr. Mário Roberto Vizioli pela sua participação essencial nas análises histológicas;

Ao Prof. Dr. Elliot Watanable Kitajima por permitir utilizar a estrutura do NAP/MEPA-ESALQ/USP.

Aos Mestres que, direta ou indiretamente, participaram na minha formação, em especial ao professores Murilo Mello, Victor A. Vitorello, Siu Miu Tsai, Luiz Eduardo Gutierrez, Walter Rodrigues da Silva, Ildegardis Bertol e Mário Nestor Ullmann;

À Prof ${ }^{\mathrm{a}}$. Sônia de Stefano Piedade pela orientação na realização das análises estatísticas;

Aos companheiros Eduardo Micotti da Glória e Maria Antonia CaloriDomingues pela amizade e sugestões tão valiosas; 
À Ivani Zambello, D. Alvica e Silvia Rúbia Rizato pela amizade e auxílio nas análises de aflatoxinas;

À Fabiana, Fabiano, Graziela, Juliana, Raquel e, em especial, à Maria Lourdes Stors, pela convivência e pela colaboração tão valiosa nos bioensaios;

À Prof. Dra. Jocelem Mastrodi Salgado por disponibilizar o biotério do Setor de Nutrição Experimental para a realização do ensaio biológico;

Aos técnicos e funcionários do Departamento de Agroindústria, Alimentos e Nutrição que de alguma forma contribuíram durante o Curso;

Aos funcionários da Biblioteca Central e da Biblioteca Setorial de Alimentos pelo atendimento e dedicação;

À Bibliotecária Beatriz Helena de Giongo pelo auxílio na revisão das citações bibliográficas;

Aos funcionários do Restaurante Universitário pelo atendimento e dedicação;

À Moradia Estudantil da ESALQ/USP, por me proporcionar auxílio moradia que foi muito importante durante esta jornada;

Aos colegas de Curso pela amizade e convivência do dia a dia;

Aos colegas da Moradia Estudantil com os quais convivi, pelo aprendizado;

Em especial, aos amigos Aderbal A. Rocha, Adonis Moreira, Alailson Santiago, Arlélio L. Santos, Amaral (CEBETC), Ana C. Lira, André Belluco, André Sesso, Anny E. Brites, Antonio Pessoa, Ariovaldo Faustino,Carlos R. França, Carla Rossi, César de Castro, Cláudia, Cláudio L. Aguiar, Cristina Lacerda, Edson Nunes, Elton Mendonça, Evandro R. Zanini, Fabiana Bruzantin, Gerbson Mendonça, Giovana Sacco, Gustavo Hildebrand, Jailson L. Fagundes, Jefferson Schick, João Batista, João C. Araújo, Jonas Ruschel, Jorge Sampaio, Juliana Iema, Júlio C. P.Santos, Karime, Luciana C. Gomes, Luciana Kolm, Luís C. Timm, Márcia Simonete, Maria Selma, Mariana P. Eduardo, Mara Pessoa, Natália Brandão, Nazareno (Naza), Patrícia Anchorena, Quelmo Novaes, Régis Heirichs, Renata Chade, Raquel Campregher, Solange Blumer, Soraia Vanessa Matarazzo,Vanderley Koefender e Wanderley Reis, com os quais tive o prazer de viver bons momentos e aprender muito. 
A todas as pessoas que me incentivaram e que, de alguma forma, contribuíram durante o Curso. 


\section{SUMÁRIO}

Página

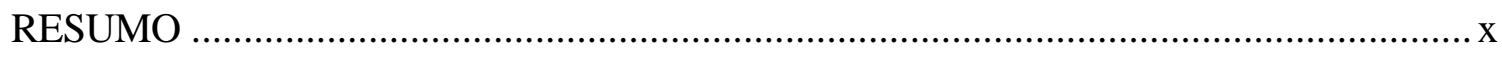

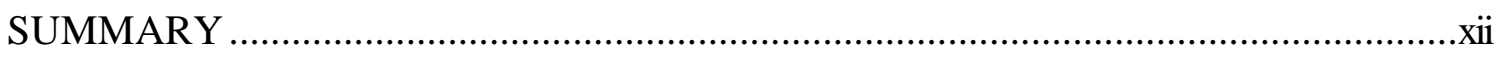

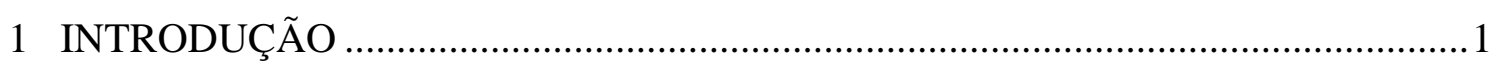

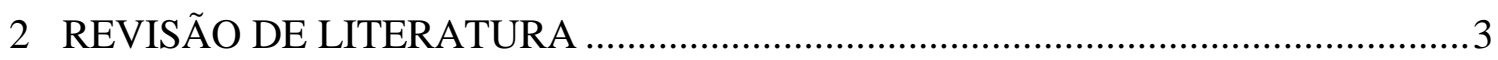

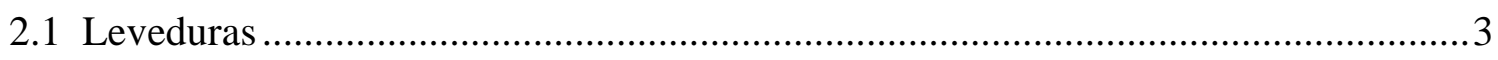

2.1.1 Importância econômica ..............................................................................

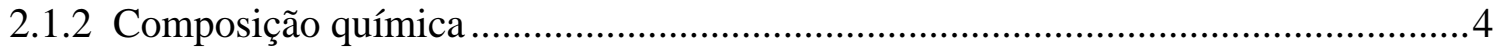

2.1.3 Fatores que interferem na viabilidade da levedura...........................................5

2.1.3.1 Teor de açúcares .........................................................................................

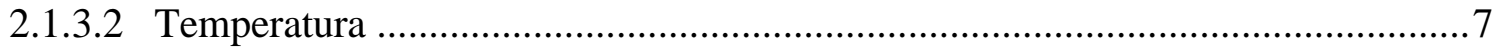

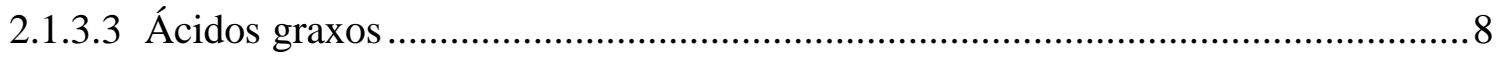

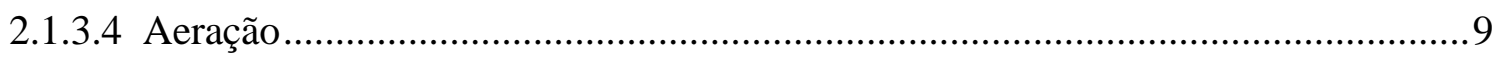

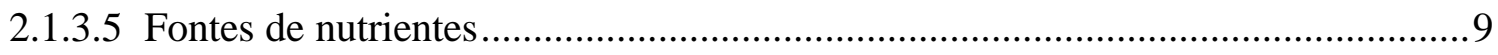

2.2 Leveduras em plantas, frutas e grãos .............................................................

2.3 Alteração de umidade e temperatura em grãos armazenados ..................................11

2.4 Avanços nos estudos do uso de leveduras .......................................................... 12

2.4.1 Aproveitamento de mananoligossacarídeos ..................................................... 12

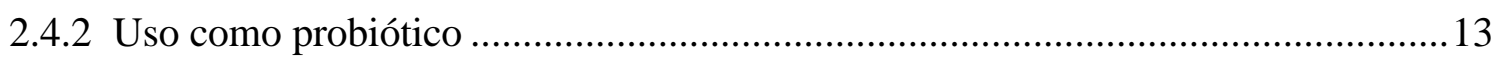

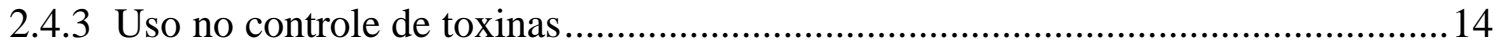

2.4.3.1 Produtos obtidos a partir de células autolisadas............................................. 14

2.4.3.2 Aplicação de células viáveis de leveduras ...................................................... 15

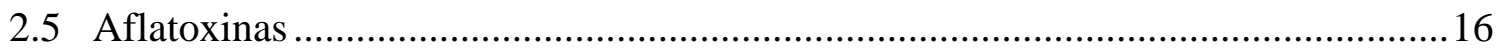

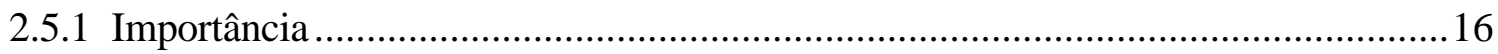




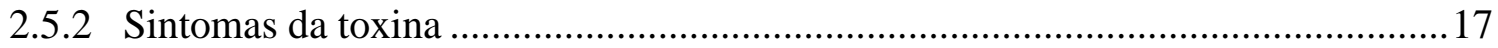

2.5.3 Alterações nos órgãos internos e tecidos ........................................................... 18

2.5.4 Alterações no sistema imunológico .......................................................................19

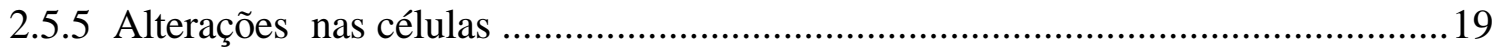

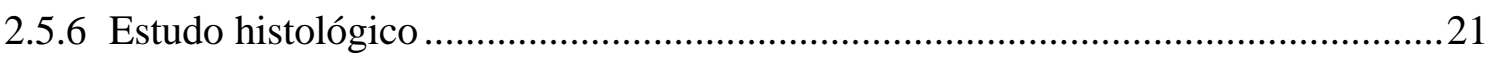

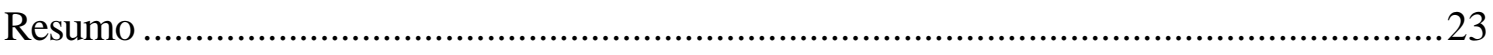

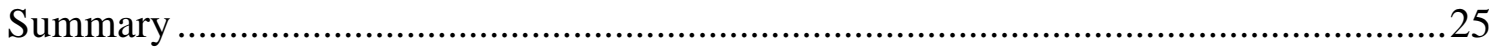

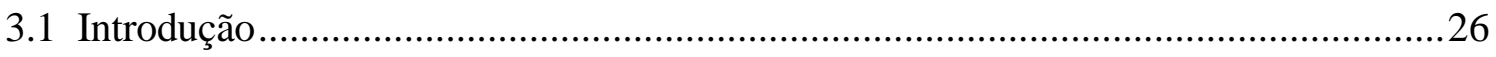

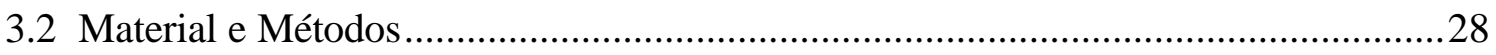

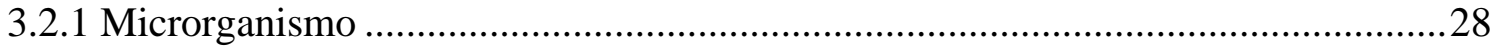

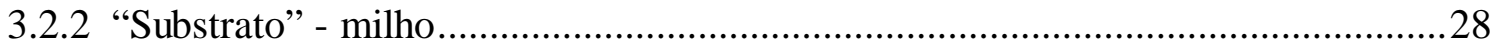

3.2.3 "Solução de Azul de metileno" 0,1\%, descrito por Pierce (1970), utilizada para avaliação da viabilidade das células de leveduras......................................28

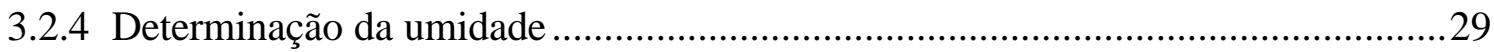

3.2.5 Condução do experimento..............................................................................29

3.2.5.1 Preparo do substrato .....................................................................................2

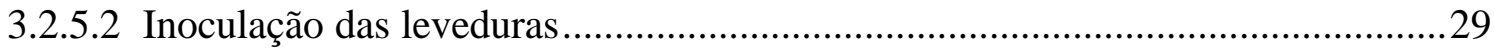

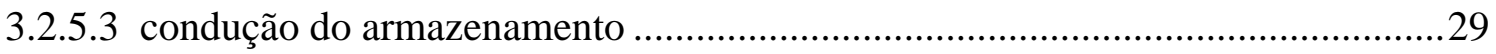

3.2.6 Determinação da viabilidade das células de leveduras ............................................30

3.2.7 Análise estatística ................................................................................................

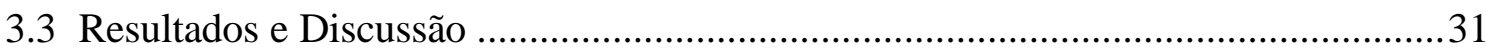

3.3.1 Influência da aplicação de diferentes concentrações de

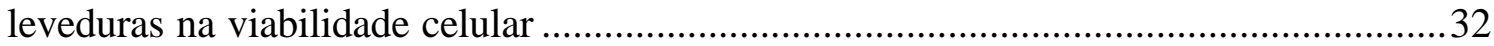

3.3.2 Comportamento celular em tratamentos com concentrações de 1 e $2 \%$

de leveduras em diferentes períodos de armazenamento ....................................................33

3.3.3 Efeito da umidade do substrato sobre a viabilidade celular de leveduras durante o armazenamento. …………….....................................................

3.3.4 Efeito do período de estocagem na viabilidade das células de leveduras ...............37

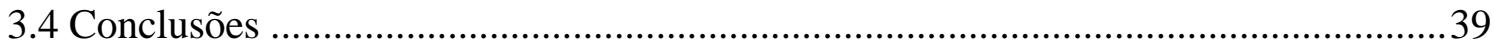

4 Saccharomyces cerevisiae E COMPONENTES DA SUA PAREDE CELULAR NA 


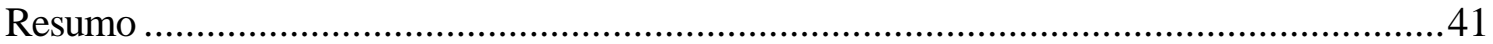

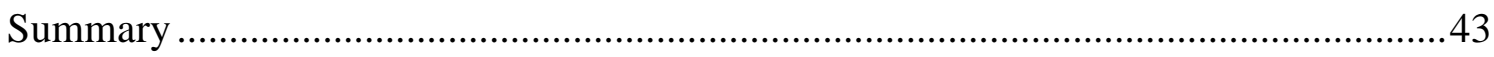

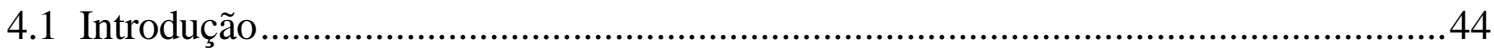

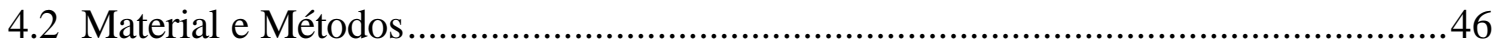

4.2.1 Microrganismos e componentes celulares utilizados ........................................46

4.2.2 Matéria-prima para contaminação das dietas ................................................. 46

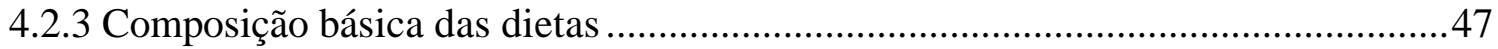

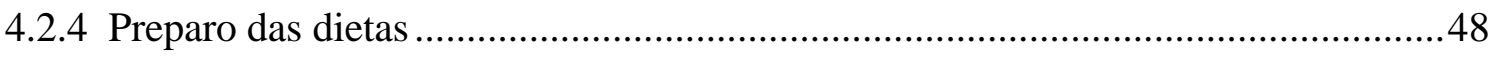

4.2.5 Composição final das dietas .................................................................. 49

4.2.6 Análise da viabilidade das leveduras ........................................................50

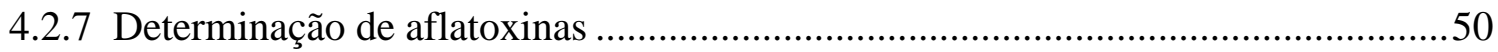

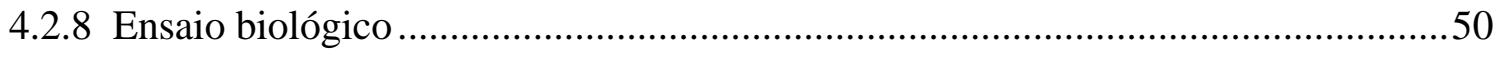

4.2.9 Parâmetros avaliados durante o bioensaio ...........................................................50

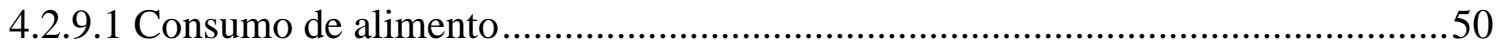

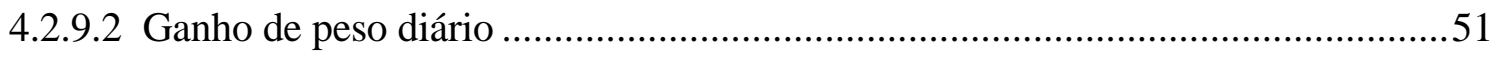

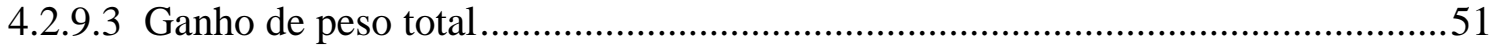

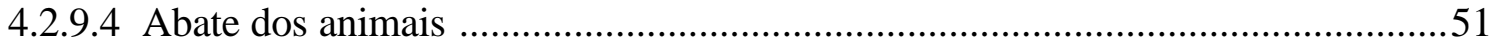

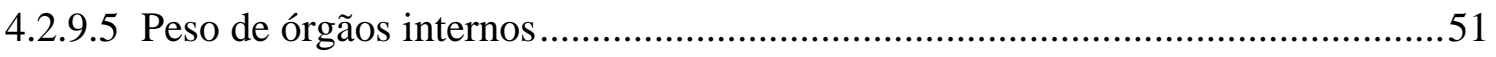

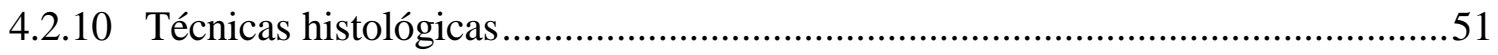

4.2.11 Observação ao microscópio ótico ..................................................................52

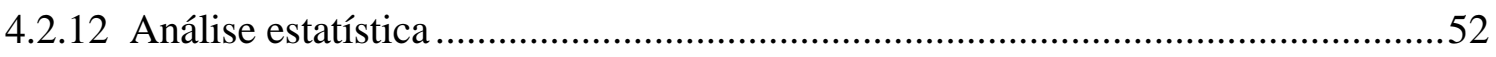

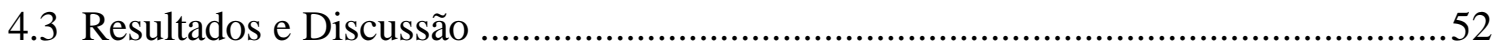

4.3.1 Consumo de alimentos e Ganho de peso.......................................................52

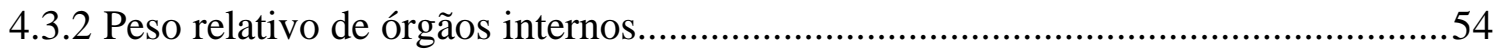

4.3.3 Estudo histopatológico dos fígados dos animais

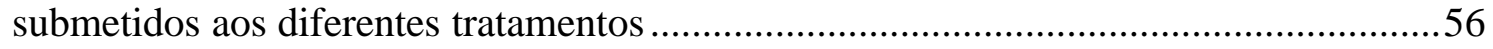

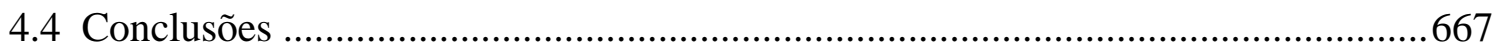

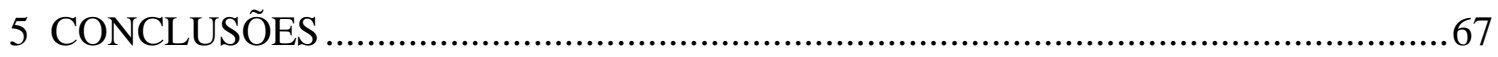

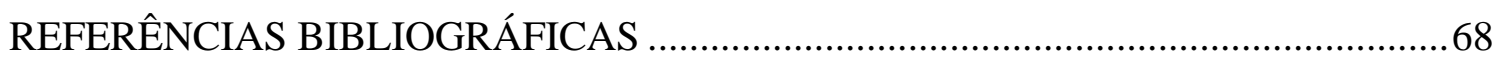




\title{
Saccharomyces cerevisiae EM MILHO ARMAZENADO E O EFEITO NA REDUÇÃO DE AFLATOXICOSES
}

\author{
Autor: ANTONIO SAMPAIO BAPTISTA
}

Orientador: Prof. Dr. JORGE HORII

\section{RESUMO}

O aproveitamento de células vivas de leveduras - Saccharomyces cerevisiae como probiótico, e, componentes extraídos da parede celular desta levedura, como aditivos, para desejadas funções, têm sido objeto de interesse cada vez maior, pelos resultados promissores até então obtidos e, concomitantemente, pelo excedente de biomassa de leveduras gerado pela indústria de etanol e cerveja no Brasil. Por estes motivos, foram conduzidos dois experimentos, um com o objetivo de investigar a possibilidade de utilizar o milho como um veículo alternativo para a levedura $S$. cerevisiae - como probiótico, e outro, com o propósito de estudar a capacidade de reduzir danos promovidos pelas aflatoxinas, das leveduras vivas, das termolisadas e mananoligossacarídeos. O primeiro experimento foi montando em um arranjo fatorial $2 \times 2 \times 5$, constituído de duas concentrações de leveduras ( 1 e $2 \%$ ), grãos de milho com dois teores de umidade (16 e 20\%) e 5 períodos de armazenamento (0, 15, 30, 90 e 110 dias), distribuído ao acaso, com 4 repetições. O outro estudo, foi um bioensaio, conduzido durante 28 dias, com ratos Wistar, em um experimento com delineamento inteiramente casualizado, com 7 tratamentos e 5 repetições.

A concentração de células aplicadas nos grãos de milho não influenciou a viabilidade das leveduras durante o armazenamento. A umidade do substrato interferiu no desenvolvimento da viabilidade, e que, em substratos com maiores teores de umidade foram observadas menores médias de viabilidade durante o armazenamento. A viabilidade das células de leveduras permaneceu constante por 30 dias e aos 90 dias em 
armazenamento foram observadas reduções no número de células viáveis. As leveduras apresentaram viabilidade de $70 \%$ aos 110 dias em armazenamento. A inoculação de leveduras vivas em grãos de milho, visando a sua utilização como probiótico, é uma técnica viável.

Os tratamentos com levedura termolisada e mananoligossacarídeos não foram capazes de reduzir os danos promovidos pelas aflatoxinas em nível de hepatócitos. As leveduras vivas foram capazes de reduzir os danos promovidos pelas aflatoxinas em nível celular. 


\title{
Saccharomyces cerevisiae IN STORED CORN AND THE REDUCTION EFFECT OF AFLATOXICOSIS
}

\author{
Author: ANTONIO SAMPAIO BAPTISTA
}

Adviser: Prof. Dr. JORGE HORII

\section{SUMMARY}

The utilization of live cells of yeasts - Saccharomyces cerevisiae - as probiotic, and, extracted components of the cellular wall of this yeast, as addictive, to desired functions, have been object of interest, due the promising results until then obtained and, simultaneously, for the excess of biomass of yeasts generated by the etanol and beer industry in Brazil. For these reasons, two experiments were led, one with the objective of investigate the possibility to use the corn as an alternative vehicle for the yeast $\mathrm{S}$. cerevisiae - as probiotic, and other, with the purpose of studying the capacity to reduce damages promoted by the aflatoxins of the live yeasts, termoliseds and mananoligossacarides. The first experiment was mounted in a factorial arrangement $2 \times 2 \times 5$, constituted of two concentrations of yeasts ( 1 and $2 \%$ ), corn grains with two moisture contents (16 and 20\%) and 5 storage periods (0, 15, 30, 90 and 110 days), random arrangement, with 4 replications. The other study, was a bioassay, led during 28 days, with rats Wistar, in completely randomzed desing, with 7 treatments and 5 repetitions.

The concentration of applied cells in the corn grains did not influence the viability of the yeasts during the storage. The moisture of the substrate interfered in the development of the viability, and that in substrate with bigger moisture contents smaller viability averages were observed during the storage. The viability of the cells of yeasts remains constant for 30 days and to the 90 days in storage reductions were observed in 
the number of viable cells. The yeasts presented viability from $70 \%$ to the 110 days in storage. The inoculation of live yeasts in corn grains, aiming its use as probiotic, is a viable technique.

The treatments with yeast termolised and mananoligossacarídes were not capable of reducing the damages promoted by the aflatoxins in hepatocites level. The live yeasts were capable to reduce the damages caused by the aflatoxins in cellular level. 


\section{INTRODUÇÃo}

A levedura é, sem dúvida, uma das mais importantes ferramentas da biotecnologia, no Brasil, sendo utilizada para a elaboração de diversos produtos; em muitos destes a sua participação é, apenas, como um agente biológico de transformação, uma vez que ao término do processo produtivo é descartada. Este fato é notório na fabricação de etanol, onde a massa celular deste microrganismo, gerada ao final da produção, é considerada um subproduto e o volume de células é tão significativo que a produção nacional de etanol pode gerar, anualmente, mais de 300 mil toneladas de biomassa de levedura. Conseqüentemente, vislumbra-se uma necessidade real de se buscar novas aplicações deste agente biológico após sua utilização em processos primários. Entre as inúmeras possibilidades, seu aproveitamento na alimentação tem ganhado importância pelos resultados promissores que tem demonstrado em pesquisas, não somente utilizada tradicionalmente como fonte proteíca, mas sim, de uma maneira mais nobre e significativa, na forma de prebiótico, através do aproveitamento de componentes da parede celular da levedura. E, na forma de um probiótico, que se fundamenta na utilização de células vivas, que promovem um reequilíbrio da microflora intestinal do hospedeiro, reduzindo bactérias patogênicas e/ou efeitos de suas toxinas.

Por outro lado, a presença em alimentos, de toxinas produzidas por fungos proporciona sérios prejuízos à saúde humana e animal.

Aliando o fato de que o excedente de leveduras é elevado e que estas podem

reduzir microrganismos patogênicos e suprimir toxinas, foram conduzidos dois experimentos com a finalidade de pesquisar um veículo alternativo para conduzi-las ao 
hospedeiro de interesse - como probiótico - e a possibilidade de utilizá-las na supressão de aflatoxinas.

Desta forma, neste trabalho são relatadas, em capítulos distintos estas duas pesquisas desenvolvidas. O primeiro capítulo trata do estudo conduzido com a levedura S. cerevisiae, com o objetivo de avaliar a viabilidade das células de leveduras quando aplicadas em grãos de milho para armazenamento e a possibilidade de utilizar os grãos de milho como veículo para a levedura como probiótico. A justificativa para esta pesquisa é o fato de que quando se deseja fornecer um probiótico a um hospedeiro, uma informação básica e fundamental é aquela que determina o veículo que se pode utilizar para conduzi-lo até o hospedeiro desejado; o milho é um dos principais componentes das dietas de animais e este se mostrou como um possível veículo para esta função. No segundo capítulo, são relatados os resultados obtidos em uma investigação realizada com diferentes fontes de leveduras, vivas, termolisadas e mananoligossacarídeos extraídos da parede celular de levedura, com o objetivo de averiguar o potencial destas fontes, em reduzir os efeitos de aflatoxinas ingeridas por ratos Wistar, uma vez que esta informação é essencial para a determinação de processos que visem a utilização de leveduras para esta finalidade. 


\section{REVISÃO DE LITERATURA}

\subsection{Leveduras}

\subsubsection{Importância econômica}

O conhecimento já existente relativo à fisiologia, bioquímica e genética das leveduras fez com que a mesma fosse escolhida como modelo básico de célula biológica para o estudo de processos metabólicos complexos. E, por serem células eucarióticas, são convenientemente adequadas para os estudos de processos biológicos peculiares dos organismos eucarióticos. Além disso, são organismos unicelulares, facilmente manipuláveis, normalmente não patogênicas, capazes de crescer em várias fontes de carbono e de fornecer grande quantidade de biomassa em tempo relativamente pequeno. (Angier, 1986).

Por outro lado, as leveduras são, sem dúvida, o grupo de microrganismos comercialmente mais explorado, uma vez que muitas das suas propriedades biológicas apresentam aplicações industriais (Rose \& Harrison, 1970)

As leveduras estão comumente envolvidas com a panificação, produção de bebidas alcoólicas e etanol. Anualmente, são produzidas em todo mundo cerca de 2 milhões de toneladas de leveduras, as quais são destinadas apenas para as indústrias de panificação, tal fato, faz deste microrganismo um dos mais importantes produtos da biotecnologia (Beudker et al., 1990).

No Brasil, as leveduras são de extrema importância para a produção de etanol e para safra 97/98 foi estimada uma produção de 15 bilhões de litros do produto, de modo que o país é o maior produtor mundial de etanol (Butolo, 1997). A disponibilidade teórica de levedura após a fermentação, como excedente, é de $2 \mathrm{~kg}$ de levedura seca por 
hectolitro produzido, que estará disponível após a sangria (Desmonts, 1966). Deste modo, na safra de 1996, foi estimado que cerca de 280.000 toneladas de leveduras poderiam ser obtidas para uso na alimentação humana e animal. Contudo, as tendências de mercado demonstraram uma previsão de produção de levedura, para a safra de 96/97, de apenas 16.000 toneladas, muito abaixo do potencial real (Butolo, 1996).

A biomassa microbiana, atualmente, utilizada com a finalidade de nutrição, é obtida de um processo no qual não é o objetivo principal da transformação e sim um subproduto da fermentação (Horii,1997).

\subsubsection{Composição química}

A composição química da levedura depende de uma série de fatores, entre os quais, podem-se destacar a natureza do substrato utilizado, grau de aeração do meio, espécie de levedura, tratamentos impostos ao meio de cultura e concentração de sais (Desmonts, 1968). Dentre estes, o substrato utilizado parece ser o mais importante, afetando a taxa de crescimento e a composição, principalmente em proteínas e lipídios (Hsu, 1961 e Vananuvat \& Kinssela, 1975).

A composição em aminoácidos das leveduras, é balanceada, destacando-se teores elevados de lisina, metionina e treonina. Os carboidratos representam 45 a $55 \%$ do peso da levedura, sendo representados em média por 33\% de trealose, $27 \%$ de glucanas, $21 \%$ de mananas e $12 \%$ de glicogênio (Rose \& Harrison, 1970).

A composição dos aminoácidos presentes na proteína de levedura pode ser utilizada como um padrão para avaliação do valor nutricional das proteínas em vegetais. A proteína é considerada de boa qualidade quando sua composição em aminoácidos essenciais apresenta-se em quantidade adequada e equilibrada, de modo a aproximar-se dos valores recomendados pelo padrão de referência da FAO/ WHO/ ONU (1985). Além disso, a palatabilidade da levedura tem a vantagem de se constituir em um atrativo (Bhattacharje, 1970).

Leveduras provenientes de sangria, em produção de etanol, foram testadas em inúmeras pesquisas com o propósito de investigar a possibilidade de utilizá-las como 
fonte de proteína, em animais de laboratório, aves, suínos e bovinos (Cozzolino, 1982; Miyada, 1978 ; Machado, 1983).

As pesquisas realizadas com a levedura de recuperação (Saccharomyces cerevisiae) têm demonstrado que este subproduto pode se constituir em uma fonte de proteína para os suínos nas várias fases do ciclo produtivo (Miyada \& Lavorenti, 1979; Lima, 1983; Menten et al., 1984; Moreira, 1984 e Berto, 1985).

Segundo Butolo (1997), a levedura pode ser utilizada em rações destinadas a frangos de corte em nível de $10 \%$. Além disso, como fonte de vitaminas do complexo $B$, foi constatado que supre a metade das exigências das aves, sendo necessário, na prática, a suplementação de apenas $50 \%$ das quantidades dessas vitaminas recomendadas.

\subsubsection{Fatores que interferem na viabilidade da levedura}

\subsubsection{Teor de açúcares}

O armazenamento após preservação de células biológicas por processo de secagem, sob baixas temperaturas, é bastante utilizado. Contudo, apresenta alguns efeitos indesejáveis, como a diminuição da viabilidade das células (Carpenter et al., 1987). Na prevenção ou redução destes efeitos adversos, a adição de algumas substâncias como a sacarose, leite em pó, glicerol, polímeros de carboidratos e outros, são recomendadas (Diniz-Mendez et al., 1999).

De acordo com Wienken (1990), organismos anidrobióticos possuem a capacidade de viver durante muito tempo no estado de desidratação, sendo resistentes ao frio, calor e seca. Esta característica de tolerância à secagem em levedura é devida à presença dos dissacarídeos trealose e sacarose (Leslie et al., 1995).

Inúmeros microrganismos são capazes de sobreviver, mais ou menos tempo completamente desidratados. Um fato comum à bioquímica deles é que acumulam grandes quantidades de dissacarídeos, dos quais os mais comuns são a sacarose e a trealose (Crowe et al., 1998). 
A trealose é um protetor natural que pode ser encontrado em vários microrganismos como as leveduras, esporos de fungos e nematóides de solo (Sussman \& Lingappa, 1959). Este dissacarídeo é usado, com sucesso, na preservação de células de leveduras quando estocadas (Coutinho et al., 1988).

Segundo Leslie et al. (1994), existe uma clara correlação entre a quantidade de trealose presente em células viáveis de $\mathrm{S}$. cerevisiae e sua habilidade em tolerar a desidratação, a altas temperaturas e o armazenamento. Estas conclusões concordam com aquelas de Suomalainen \& Pfaffli (1961) e Panel et al. (1993), os quais verificaram que em leveduras de panificação, a manutenção da viabilidade celular era devida a trealose, a qual apresenta a função de proteger as células contra a autólise.

Linhagens de Saccharomyces cerevisiae apresentaram uma viabilidade celular de 35\%, após 25 dias, quando armazenadas em neio sem nutriente, ao passo que na deficiência de trealose, estas permaneceram viáveis, por apenas 14 dias (Panek 1985).

Existem controvérsias quanto a função da trealose em esporos de leveduras; de um lado, acredita-se que a trealose atue no suprimento de energia, em esporos de leveduras (Barton et al., 1982); por outro lado, se atribue à trealose a função de fornecer energia durante a dormência, e não durante o processo de germinação, dos esporos de Saccharomyces cerevisiae (Donnini et al., 1988).

Segundo Crowe et al. (1984), a trealose possui capacidade de proteger as células de leveduras durante processos de desidratação-hidratação. Tal habilidade é atribuída ao fato de que a trealose interage com os grupos polares das cadeias fosfolipídicas existentes na membrana celular. Neste fenômeno, ocorre a substituição das moléculas de água pela trealose, assim, em condiçõos de estresse, são evitadas as separações laterais de componentes da membrana, mantendo-se a integridade e fluidez da mesma e, com isso a viabilidade celular (Panek et al., 1993).

Segundo Thevelein (1984), o acúmulo de trealose está associado a períodos de reduzida taxa de crescimento. Sua síntese é mais intensa durante o processo de diferenciação e os períodos de deficiência de nutrientes.

Os carboidratos de reserva, glicogênio e trealose, exercem importantes funções durante o ciclo de vida das leveduras, e estão envolvidos com a manutenção, 
diferenciação e sobrevivência das células. Estes, atuam como reservas de energia durante todas as fases do ciclo vital das células. Este fato pode significar que, células de leveduras com maiores teores destes açúcares podem apresentar maior capacidade de permanecerem viáveis quando em armazenamento (Panek , 1962; Panek 1963)

A trealose e o glicogênio podem possuir duplo papel; sob condições de restrição de carbono servem como um fator de proteção e manutenção da viabilidade das células durante a estocagem e, sob condições melhores, suprir, rapidamente, o fluxo de carbono e ATP às células (Sillje et al., 1999).

Existe uma forte relação entre concentrações de glicerol e de trealose intracelular e a capacidade de células de leveduras em tolerar estresses osmóticos severos, com manutenção da viabilidade celular (Hounsa et al., 1998).

\subsubsection{Temperatura}

A temperatura é uma das condições ambientais que mais afetam a atividade de microrganismos, influenciando no crescimento, metabolismo, capacidade fermentativa e viabilidade celular em leveduras (Alcarde, 1996).

A temperatura de secagem pode afetar a viabilidade das células de leveduras durante o armazenamento, uma vez que interfere nos teores de carboidratos totais, trealose, nitrogênio total e proteínas em células de leveduras submetidas à secagem (Dalaly \& Tawfeel, 1987).

Em experiência com diferentes temperaturas de secagem, 40, 50 e $60^{\circ} \mathrm{C}$, para investigar o efeito sobre a viabilidade de células de leveduras, foi verificado que a melhor temperatura de secagem foi $50^{\circ} \mathrm{C}$, quando as células de leveduras apresentaram maior atividade e viabilidade após a secagem (Dalaly \& Tawfeel, 1987).

A capacidade de células de leveduras em sobreviver a um choque térmico drástico em curto período de tempo está intimamente ligada a tratamentos térmicos prévios, como um choque térmico não letal, 40 - $45^{\circ} \mathrm{C}$, (Bossier et al., 1993). De 
acordo com Hottinger et al. (1987), a elevação da temperatura do meio de cultivo de Saccharomyces cerevisiae de 27 para $40{ }^{\circ} \mathrm{C}$ promove um aumento no acúmulo de trealose e com isso a levedura adquire termotolerância.

Segundo Piper (1993), a tolerância de leveduras ao estresse térmico é induzida por choques térmicos. Hottinger et al. (1987b), afirmam que o choque térmico proporciona um aumento na atividade da enzima responsável pela biossíntese de trealose, a trealose-6-fosfato-sintetase, e que esta enzima possa ser uma proteína do choque térmico.

Em condições de choque térmico há um acúmulo de trealose, fato que propicia um aumento na estabilidade das proteínas em células intactas, permitindo melhor preservação da viabilidade das células de leveduras (Hottinger et al., 1994).

Em leveduras termotolerantes, Nwaka et al. (1994) sugerem que, sob certas condições, o acúmulo de proteínas ocorrido com o choque térmico é responsável pela termotolerância. Este fato pode complementar a afirmação de Arguelles (1994) que supôs que, além do acúmulo de trealose, existem outros fatores relacionados com a termotolerância.

\subsubsection{3 Ácidos graxos}

A composição lipídica da membrana celular das leveduras é condicionada pela temperatura durante a fermentação. Tal fato pode afetar a viabilidade das células durante o armazenamento (Farrell \& Rose, 1967).

A perda de viabilidade em células de leveduras por ocasião do armazenamento pode ser atribuída às alterações nas funções da membrana celular, ocasionadas pela falta de esteróis e ácidos graxos insaturados (Wilson \& Mcleod, 1976).

As propriedades físico-químicas dos lipídios da membrana citoplasmática são influenciadas por ácidos graxos, que são de fundamental importância para o desenvolvimento de microrganismos, sob diferentes temperaturas (Watson \& Cavicchioli, 1976; Suutari et al., 1990). 


\subsubsection{Aeração}

O número de células, a viabilidade, o nível intracelular de açúcares de reserva e o teor de ácidos graxos são maiores em cultivos de leveduras conduzidos sob condições de aerobiose do que sob condições de anaerobiose; tais diferenças influenciam diretamente no comportamento das mesmas na ocasião da estocagem (Maemura et al., 1998).

\subsubsection{Fontes de nutrientes}

O cultivo de leveduras em meio com baixo teor de nitrogênio assimilável apresenta acentuada síntese de carboidratos e isso pode afetar a viabilidade das células (Trevelyan \& Harrison, 1956 e Soumalainen \& Pfaffli, 1961). Estas conclusões também foram tiradas por Lillie \& Pringle (1980) quando verificaram que células de leveduras que sofrem restrição de nutrientes como o enxofre e o fósforo, acumulam grande quantidade de carboidratos de reserva, demonstrando que o acúmulo destes açúcares, pode ser proporcionado, de uma maneira geral, pela limitação de nutrientes no substrato de crescimento. Identicamente, Szopa et al. (1992) verificaram que em meio com restrição de fósforo e nitrogênio havia um estímulo ao acúmulo de trealose, influenciando no comportamento da viabilidade das células ao serem estocadas.

Conforme descrito por Walker (1998), o magnésio pode atuar na célula prevenindo a integridade estrutural e funcional da membrana plasmática dos danos induzidos por estresses, sendo que estas células, por apresentarem melhor integridade de membrana plasmática podem apresentar e preservar melhor sua viabilidade durante o armazenamento.

\subsection{Leveduras em plantas, frutas e grãos}

A presença de leveduras foi constatada em uma grande diversidade de habitats naturais como grãos, flores, folhas, sementes de frutas, exsudado de árvores, insetos e solos (Miller et al., 1962; Do Carmo-Sousa, 1969). 
Ao investigar a ecologia da superfície de bagas de uvas, a fim de identificar as espécies ali existentes, foi verificado que as espécies do gênero Saccharomyces eram as mais comuns e abundantes (Rosini et al., 1982).

Ao analisar a microbiota presente na superfície de mamão e acerola, foi observado que as leveduras representavam um dos mais importantes grupos de microrganismos presentes na superfície daquelas frutas durante a colheita, processamento e manipulação, as quais podiam promover fermentações, afetando a qualidade do produto. Entre as leveduras encontradas, as mais importantes foram as da espécie Saccharomyces cerevisiae (Oliveira et al., 2000).

Podem ser encontradas leveduras em grãos armazenados, na superfície de bagas, suco de frutas, xaropes e melaços (Barnett et al., 1990 e Lacey \& Magan, 1991). De acordo com Paster et al. (1993), as leveduras são capazes de permanecerem viáveis e se multiplicarem quando aplicadas em grãos de soja.

Cereda et al. (1989), citam que sobre caldo de grãos de sorgo sacarino em fermentação natural, foram isoladas 65 leveduras, distribuídas em 7 gêneros e que, entre as espécies identificadas foram encontrados exemplares de Saccharomyces cerevisiae; os autores verificaram a possibilidade de sobrevivência deste microrganismo naqueles grãos.

Analisando a ecologia microbiana presente em grãos de café foi verificado que as leveduras do gênero Saccharomyces, principalmente as espécies $S$. marxianus, $S$. bayanus e $S$. cerevisiae eram habitantes naturais daquele ambiente. Estes microrganismos sobreviviam sobre a mucilagem dos grãos, os quais eram responsáveis pela fermentação de carboidratos ali existentes (Agate \& Bhat,1966). Ao estudar estes carboidratos, que servem de substrato para as leveduras, foram encontrados principalmente pectinas, açúcares redutores e sacarose (Lee, 1975, citado por Jones \& Jones, 1984).

No tocante à capacidade de sobrevivência de leveduras em grãos, foi verificado que ao inocular $10^{5}$ UFC de leveduras, por grama de grãos de trigo, decorrido um determinado período de tempo, foi alcançada uma população de $10^{7}$ UFC de leveduras, 
por grama de trigo, indicando a capacidade de sobrevivência e crescimento, sobre aquele substrato durante a investigação (Peterson \& Schnürer, 1995).

As células de leveduras apresentam capacidade de permanecerem viáveis e crescerem, quando inoculadas em grãos de trigo, aveia e cevada. E ainda, a inoculação de baixas concentrações de Saccharomyces cerevisiae sobre grãos de trigo para armazenamento, promove na primeira semana, um crescimento lento, contudo, há um rápido crescimento durante a segunda semana (Petterson \& Schnürer, 1995).

No que tange a viabilidade celular de Saccharomyces cerevisiae em grãos para armazenamento, os teores de umidade do substrato e o veículo de aplicação utilizado interferem no comportamento da viabilidade das células (Baptista et al., 1999).

\subsection{Alteração de umidade e temperatura em grãos armazenados}

Estudos têm demonstrado que o teor de umidade de grãos em armazenamento, pode variar em diferentes regiões de uma célula de silo. Assim, mesmo que os grãos

tenham sido armazenados com baixos teores de umidade, algumas áreas do depósito podem apresentar níveis de umidade maiores do que outras, em decorrência da migração de umidade (Puzzi, 1986).

Segundo Christensen \& Kaufmann (1969), grãos de trigo armazenados com $12,2 \%$ de umidade, apresentaram na época da descarga, amostras com teores de 16 a $18,5 \%$ de umidade.

O aumento de umidade ocorre devido aos processos respiratórios dos grãos, insetos e microrganismos. Com a respiração, ocorre um aquecimento e aumento da umidade na massa de grãos pela liberação de energia. Uma vez que, este processo formulado por meio de um carboidrato, a glicose $\left(\mathrm{C}_{6} \mathrm{H}_{12} \mathrm{O}_{6}\right)$ pode resultar no seguinte:

$$
\mathrm{C}_{6} \mathrm{H}_{12} \mathrm{O}_{6}+6 \mathrm{O}_{2} \rightarrow 6 \mathrm{H}_{2} \mathrm{O}+6 \mathrm{CO}_{2}+677,2 \mathrm{cal}
$$

Quando a liberação de energia e água é mais rápida do que a perda, ocorre o aquecimento do substrato e aumento da umidade (Lacey \& Magan, 1991). 


\subsection{Avanços nos estudos do uso de leveduras}

\subsubsection{Aproveitamento de mananoligossacarídeos}

Ao ministrar um alimento para um indivíduo, podem ocorrer grandes impactos ao seu sistema imunológico, de modo que alguns aditivos podem trazer benefícios ao sistema de defesa do organismo. Entre estes, um aditivo que tem enorme potencial é o extrato de levedura, mais especificamente um carboidrato funcional que pode ser extraído da parede celular das células de leveduras (Spring, 2000).

Investigações com monogástricos tem demonstrado que alguns dos efeitos benéficos das leveduras a estes hospedeiros podem estar associados à sua parede celular, onde existem oligossacarídeos expressos na forma de mananoproteínas, que quando fornecidas a monogástricos parecem melhorar a saúde e o desempenho destes, uma vez que são potentes modificadores da microflora intestinal (Spring, 1998).

Os mananoligossacarídeos possuem habilidade para reduzir a prevalência de certas bactérias patogênicas e impedir a colonização do trato gastrointestinal (Spring, 1998). Segundo Dawson \& Pirvulescu (1999), a maior parte dos patógenos liga-se a manana para facilitar a colonização do trato gastrointestinal, contudo, as mananas derivadas de leveduras não são digeridas no trato gastrointestinal, assim, as mananas atuam como um substrato ao qual aderem-se os patógenos, de modo que agem sequiestrando-os e eliminando-os.

Em estudo recente, foi realizada uma triagem para avaliar o mecanismo de adesão de Escherichia coli no trato intestinal. Das cepas testadas, foi verificado que $66 \%$ delas, manifestaram expressão de fímbrias específicas para manose, indicando que estas podem reconhecer este açúcar e se aderir ao mesmo (Finucane et al., 1999).

Várias pesquisas demonstraram a capacidade dos mananoligossacarídeos em exercer efeitos supressores sobre outras bactérias patogênicas como Salmonella, Clostridios e Campylobacter (Dawson \& Pirvulescu, 1999; Finucane, 1999).

No que concerne ao mananoligossacarídeo, preparações de parede celular de leveduras contendo este carboidrato, quando adicionadas a dietas de animais, demonstraram estimular a função de defesa imunológica (Dawson \& Pirvulescu, 1999). 


\subsubsection{Uso como probiótico}

De acordo com Fuller (1989), probiótico pode ser entendido como um suplemento alimentar que adiciona microrganismos vivos, que afetam, beneficamente, o hospedeiro por promover um melhor balanço na microbiota intestinal.

O fornecimento de probiótico a um indivíduo pode trazer vários benefícios, entre os quais, aumento da resistência a doenças infecciosas; diminuição da duração de diarréia; redução da pressão sanguínea; estímulo da fagocitose por leucóticos periféricos do sangue; redução de sensibilidade a alergias; regressão de tumores; redução da produção de carcinogênicos e co-carcinogênicos; aumento da taxa de crescimento; melhoria da eficiência alimentar e aumento de produção (Bloksma et al., 1979; Kato et al., 1981; Fernandes et al., 1987; Sawada et al., 1990; Fuller, 1992; Perdigon \& Alvarez, 1992; Saavedra et al., 1994).

A levedura (Saccharomyces cerevisiae) como um ingrediente não convencional é de elevado valor biológico. Embora seja considerada como fonte de proteínas, pode ser utilizada como suplemento vitamínico, como fonte de metabólitos não identificados com ação de promotor de crescimento e promotor de reequilíbrio da microflora intestinal (Butolo, 1997).

Tem sido também aconselhado o uso da levedura (Saccharomyces cerevisiae) viva para a alimentação, sendo recomendada, a adição de $10 \mathrm{~g}$ de células de leveduras vivas, por animal, por dia. Neste nível de nclusão, seu efeito não pode ser como fonte de proteína e sim como metabólico ou probiótico (Machado, 1997).

De acordo com Dawson (1993), a levedura estimula o crescimento e a atividade de bactérias que degradam as fibras aumentando a produção dos ácidos, acético, propiônico e lático. Com isso, pode ocorrer melhor digestão dos alimentos e maior aproveitamento da energia e da proteína.

A microbiota gastrointestinal é considerada, na maioria das vezes, metabolicamente adaptável e rapidamente renovável no organismo. Este fato é muito 
importante porque a flora existente neste "habitat" executa um papel vital para o funcionamento normal do hospedeiro quanto aos aspectos nutricional, fisiológico, imunológico e protetor. (Leedle, 2000). Esta constatação corrobora com a de Dawson (1993), ao afirmar que, o fornecimento de leveduras a um hospedeiro pode alterar a fisiologia deste, pois ao absorver o oxigênio existente no meio, este torna-se mais anaeróbico, e que modifica, de maneira favorável, o desenvolvimento de bactérias. Assim, é fundamental que a levedura esteja viva e/ou metabolicamente ativa para exercer sua função.

\subsubsection{Uso no controle de toxinas}

\subsubsection{Produtos obtidos a partir de células autolisadas}

O Mycosorb $^{\circledR}$, uma formulação composta por mananoligossacarídeos, na dosagem de $0,05 \%$ quando adicionado em dieta de aves, contendo $5 \mathrm{mg} \cdot \mathrm{kg}^{-1} \mathrm{de}$ aflatoxinas, durante 3 semanas, proporcionou um ganho de peso de $16 \%$, em relação ao peso médio do grupo controle, com aflatoxinas (Stanley et al., 1996).

Segundo Mahesh \& Devegwoda (1996), em estudo in vitro, foi observado

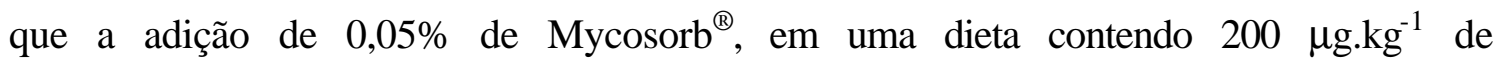
aflatoxinas, proporcionou o sequiestro por parte deste componente de $79 \%$ das toxinas.

Stanley et al. (1996), observaram que a fornecer 0,05\% de Mycosorb ${ }^{\circledR}$, em dieta contendo $5 \mathrm{mg} \cdot \mathrm{kg}^{-1}$ de aflatoxinas, durante 3 semanas, sob temperatura controlada de $21^{\circ} \mathrm{C}$, o peso relativo do fígado dos animais foi maior do que o dos animais que receberam 5mg. $\mathrm{kg}^{-1}$ de aflatoxinas sem o aditivo, contudo, os dados obtidos não diferiram estatisticamente. Por outro lado, os autores observaram que ao fornecer $0,05 \%$ de Mycosorb ${ }^{\circledR}$ em dieta contendo $5 \mathrm{mg} \cdot \mathrm{kg}^{-1}$ de aflatoxinas, durante 3 semanas, sob temperatura controlada de $32{ }^{\circ} \mathrm{C}$, o peso relativo do fígado foi menor do que o dos animais que receberam 5mg.kg-1 de aflatoxinas, sem o aditivo e diferindo estatisticamente. 


\subsubsection{Aplicação de células viáveis de leveduras}

Para neutralizar a severidade de dieta contendo aflatoxinas, o efeito de Saccharomyces cerevisiae tem sido reconhecido por diminuir o estresse em animais, ser fonte de vitaminas e conter um fator de crescimento, não identificado, que reduz o estresse (Phillips \& Von Tungeln, 1984), contém enzimas e proteína (Crumplen et al., 1989; Krause et al., 1989).

Em uma investigação conduzida para verificar o efeito de duas concentrações $(0,05 \%$ e $0,1 \%)$ de Saccharomyces cerevisiae vivas na dieta, e concentração de $5 \mathrm{mg} \cdot \mathrm{kg}^{-1}$ aflatoxinas, fornecidas à frangos de corte, foi observado que os animais que receberam tratamento com $0,1 \%$ de levedura e $5 \mathrm{mg} \cdot \mathrm{kg}^{-1}$ de aflatoxinas obtiveram ganho de peso de cerca de $15 \%$, maior do que aqueles que receberam dietas contaminadas com aflatoxinas, sem a adição de leveduras (Stanley et al., 1993). Estes mesmos autores observaram que, os pesos relativos dos órgãos internos, fígado, coração e proventrículo aumentaram, significativamente, com a adição de $5 \mathrm{mg} \cdot \mathrm{kg}^{-1}$ de aflatoxinas; os pesos relativos destes órgãos foram semelhantes ao do controle, sem aflatoxinas, nos animais que receberam dietas contaminadas com $5 \mathrm{mg} \cdot \mathrm{kg}^{-1}$ da toxina e a adição de $0,1 \%$ de leveduras vivas.

Uma possível explicação para o fato de leveduras poderem neutralizar efeitos de aflatoxinas, pode ser a de que, pela sua adição, concomitantemente, há um incremento de enzimas, que podem contribuir para a melhor utilização dos alimentos (Sullivan et al.,1978). De acordo com Mgbodile et al (1975), há uma gama de enzimas biológicas produzidas por alguns microrganismos que têm a habilidade de descontaminarem dietas, no que refere-se às aflatoxinas. Além disso, Dalvi \& McGowan (1984), concluíram que a indução de enzimas microssomáticas é um importante fenômeno toxicológico, que poderia acelerar a bio-transformação de certas toxinas in vivo, assim, alterando a duração e a intensidade dos efeitos tóxicos.

Após a adição de $0,1 \%$ de leveduras vivas à dieta contaminada com aflatoxinas, foram verificados aumentos nas atividades das enzimas alanina transferase, aspartato aminotransferase, lactato desidrogenase e creatina fosforoquinase, sugerindo 
que a severidade das aflatoxinas foi reduzida, com isso, aumentando a biodisponibilidade de nutrientes (Stanley et al., 1993).

Segundo Cooney (1980), é possível que S. cerevisiae suprima a severidade de aflatoxicoses através de quelação, ligando-se com as aflatoxinas, que são assim, eliminadas pelo trato intestinal.

\subsection{Aflatoxinas}

\subsubsection{Importância}

Segundo Heathcote (1984), as aflatoxinas são metabólitos secundários, tóxicos, produzidos por algumas linhagens de Aspergillus flavus e A. parasiticus, além de outras espécies como A. nomius (Frisvad \& Thrane, 1996). Sob condições favoráveis de temperatura e umidade, estes fungos podem crescer em certos alimentos, resultando na produção de aflatoxinas (Fortnum, 1986; Lillehoj, 1986).

As principais aflatoxinas produzidas pelos fungos são B1, B2, G1, e G2. Com relação aos efeitos tóxicos, das aflatoxinas, foi verificado que as quatro principais aflatoxinas apresentam o seguinte grau de toxicidade: $\mathrm{B} 1>\mathrm{G} 1>\mathrm{B} 2>\mathrm{G} 2$. Destas, a mais tóxica e cancerígena é a Bl (Carnaghan et al., 1963).

No mundo todo, há uma crescente conscientização das sérias conseqüências que a ingestão de concentrações elevadas de aflatoxinas pode causar à saúde humana e dos animais (FAO, 1993) e mesmo as concentrações baixas, desde que continuamente.

A exposição às concentrações crônicas é mais provável do que às concentrações agudas e existem evidências, que levam a crer, que o consumo de concentrações crônicas, de aflatoxinas, provavelmente, conduzam ao câncer. Assim, as exposições a concentrações crônicas destas toxinas representam sérios problemas para a saúde pública (Roebuch \& Maxuilenko, 1994).

Os efeitos das aflatoxinas podem ser bioquímicos e biológicos. Bioquimicamente, as aflatoxinas podem afetar o metabolismo de energia, de carboidratos e de lipídios e também dos ácidos nucléicos e das proteínas. Os efeitos 
biológicos são carcinogenicidade, mutagenicidade, teratogenicidade, hepatotoxicidade e aflatoxicoses (Ellis et al., 1991; Bradburn \& Coker,1993).

O impacto econômico resultante da contaminação por aflatoxina ocorre em todas as etapas da produção vegetal e animal, comercialização e utilização dos produtos (Kubena et al., 1990). A facilidade e freqüência com que as aflatoxinas contaminam os produtos agrícolas, e ao mesmo tempo, a exposição de animais a níveis crônicos destes compostos químicos, via dieta contaminada, podem ser as principais diferenças entre o lucro e o prejuízo para atividade agroindustrial (Jones et al., 1982; Nichols, 1983; Hamilton, 1984).

Em muitos países, os níveis permitidos de aflatoxinas em produtos alimentícios estão entre 5 a $50 \mu \mathrm{g} \cdot \mathrm{kg}^{-1}$ (FAO, 1993). No Brasil, a presença de aflatoxinas nos alimentos é regulada pela Resolução № 34.176 do Ministério da Saúde (Brasil, 1977), que estabelece $30 \mu \mathrm{g} \cdot \mathrm{kg}^{-1}$ para a somatória das aflatoxinas B1 e G1, e mais recentemente, internalizando as normas do Mercosul, pela Portaria Nㅜ 183 do dia 21 de março de 1996, do Ministério da Agricultura do Abastecimento e da Reforma Agrária, que estabelece o limite máximo de $20 \mu \mathrm{g} \cdot \mathrm{kg}^{-1}$, para a somatória das aflatoxinas B1, B2, G1, e G2 (Brasil, 1996).

\subsubsection{Sintomas da toxina}

As aflatoxinas podem causar danos ao fígado, na maioria dos animais domésticos e experimentais (Stark, 1986) e têm sido relacionadas com muitas doenças em humanos, incluindo hepatocarcinoma. Embora o fígado seja o alvo primário, em muitos casos, lesões cancerígenas foram observadas nos rins, cólon, pulmão e glândulas lacrimais de vários animais alimentados com rações contaminadas por aflatoxinas (Stoloff, 1977).

Em animais, os sintomas clínicos mais comuns são: anorexia, diminuição dos ganhos de peso, diminuição da utilização do alimento ingerido, hemorragia e suceptibilidade ao meio ambiente, além do estresse por microrganismos (Edds \& Bortel, 1983). 
Salgado (1978), trabalhando com ratos da linhagem "Wistar", com idade na faixa de 35 a 55 dias, em biensaios, cujas dietas estavam contaminadas com micotoxinas, provocadas por fungos do gênero Aspergillus, pôde observar que os animais ganharam peso no início do bioensaio, atingiram um ponto máximo e depois passaram a perder peso até os 10 dias do experimento, devido aos efeitos tóxicos de micotoxinas produzidas por estes fungos.

Segundo Barnes \& Butler (1964), os ratos parecem ser, em parte, resistentes à aflatoxina, uma vez que são capazes de sobreviver por um curto período experimental alimentando-se com uma dieta contendo altas concentrações de farelo tóxico. Entretanto, em investigação por período prolongado com ingestão, de cerca, de $20 \%$ da dieta contaminada com a toxina, foram observadas reduções na taxa de crescimento dos animais e do consumo do alimento. Uma alimentação prolongada, de várias semanas, poderá originar lesões no fígado e hepatomas (Lancaster et al., 1961).

\subsubsection{Alterações nos órgãos internos e tecidos}

As aflatoxinas são metabolizadas no fígado e, portanto, os sintomas primários destas micotoxicoses se apresentam como alterações histológicas neste órgão. Em ratos e patinhos os sintomas iniciais são caracterizados por necroses hepáticas (Theron, 1965; Clifford \& Rees, 1967).

Tem sido atribuído às aflatoxinas casos de deficiência nutricional, diminuição de peso corporal e aumento de fígado e proventrículo em animais (Huff et al., 1986; Kubena et al., 1990).

Em estudos com ratos que receberam alimentação, contaminada com aflatoxinas, por 30 semanas, foi verificado que estes apresentavam lesões no fígado e tumores múltiplos, incluindo carcinoma. Por outro lado, doses de 50 e $500 \mu \mathrm{g}^{\mathrm{kg}}{ }^{-1} \mathrm{de}$ aflatoxinas B e G, aplicadas na forma de injeções subcutâneas, em ratos produziram, simultaneamente, sarcomas e fibrosarcomas, após 20 a 21 semanas (Dickens \& Jones, 1963). 
Os pesos médios do fígado, coração e proventrículo aumentaram, significativamente, em animais que receberam dietas contaminadas com 5 mg.kg de aflatoxinas, quando comparados com os pesos médios relativos destes órgãos de animais que receberam dietas livres de aflatoxinas (Stanley et al., 1993).

Dietas contendo de 250 a $500 \mu \mathrm{g} \cdot \mathrm{kg}^{-1}$ de aflatoxina $\mathrm{B}_{1}$, fornecidas para perus, durante várias semanas, levaram às alterações nos teores de lipídios dos hepatócitos do fígado e hiperplasia do epitélio do ducto biliar (Píer \& Heddleston, 1970; Newberne, 1973).

\subsubsection{Alterações no sistema imunológico}

As aflatoxinas prejudicam as células e o sistema humoral, tornando o indivíduo mais susceptível às infecções por bactérias, vírus, fungos e doenças parasitárias (Rodricks \& Stoloff, 1977; Cysewski et al., 1978; Miller et al., 1978; Bouton et al., 1980; Thurston et al., 1980; Harvey et al., 1988).

Baixas concentrações de aflatoxinas na dieta pode reduzir a resistência de frangos à Pasteurella, Salmonella, Coccidia e Candida e, aumentar a severidade de desinterias por infecção causadas por Erysipelotrix rhusiopathiae e Salmonelloses em suínos (Píer \& Heddleston, 1970; Richard et al., 1975; Cysewski et al., 1978; Miller et al., 1978, Joens et al., 1981).

\subsubsection{Alterações nas células}

As aflatoxinas causam alteração no metabolismo de carboidratos e prejudicam o transporte de lipídios, resultando em diminuição nas concentrações de glicose e acúmulo de lipídios dentro dos hepatócitos (Wogam, 1973; Rodricks \& Stoloff, 1977; Heathcote e Hibbert, 1978; Naber e Wallace, 1979).

A saúde do indivíduo depende, basicamente, da saúde das células que compõem o seu organismo. É claro que, para que a saúde do organismo seja alterada de uma forma sensível, não basta que poucas células sejam afetadas, mas um grande 
número delas. A doença é atribuída à perturbação do equilíbrio homeostático, de um número significativo de células, de um determinado órgão ou território do organismo (Vizioli, 1996).

Segundo Robbins et al. (1986), a célula normal não existe em um estado funcional e morfológico rigidamente fixo. Esta passa por variações na estrutura e na função, refletindo as mudanças cambiantes da vida. Assim, quando ocorre algum estresse na célula, dentro de certos limites, esta se adapta e alcança um novo estado de equilíbrio alterado, permitindo a sua sobrevivência dentro do ambiente alterado.

Quando os limites de adaptação são ultrapassados, instala-se uma lesão celular, que pode ser reversível, quando a causa que provoca a lesão celular é moderada ou cessa, e, pode ser irreversível quando a agressão sofrida é intensa e não cessa, levando à morte da célula (Robbins et al., 1986; Vizioli, 1996).

Os processos quem induzem, em célula, estados morfológicos alterados são diversificados, de modo que entre as amplas categorias de influências adversas que a afetam a função celular se encontram a hipóxia, agentes físicos, produtos químicos e drogas, agetnes microbiológicos, mecanismos imunológicos, defeitos genéticos, envelhecimento e radicais livres (Robins et al., 1986).

A hipóxia é uma das causas mais importantes e freqüentes de lesão celular e pode ocorrer em diferentes situações patológicas. Esta intercede com a respiração aeróbica, assim, uma das causas mais comuns é o inadequado suprimento sangüíneo de um órgão ou região deste órgão, com isso o suprimento sanguiíneo que chega à célula é menor do que o requerido (Robbins et al., 1986; Vizioli, 1996).

Ainda, de acordo com Vizioli (1996), em alguns casos de hipóxia há queda da energia celular, por perda de ATP (adenosina trifosfato), e conseqüente aumento de AMP (adenosina monofosfato). Isso leva à queda do $\mathrm{pH}$ intracelular, com desequilíbrio iônico, de modo que a célula perde $\mathrm{K}^{+}$e fixa $\mathrm{Na}^{+}$; como conseqüência, ocorre acúmulo de água intracelular, originando edema celular, que está relacionado com a homeostase celular. 
Em caso de edema, onde as células de um órgão estão comprometidas, é observado um aumento geral no peso e no tugor deste, além de palidez do mesmo (Robbins et al., 1986).

Conforme Robbins et al. (1986), em alguns casos podem ocorrer lesões mais sérias, observadas pela manifestação de alteração gordurosa nas células. Embora reversível, esta alteração é um prenúncio de morte celular. Esta alteração implica em um imbalanço dos percussores de lipídios intracelulares. Às vezes, é precedida de edema celular, e é mais freqüentemente encontrada nas células hepáticas. Tanto a alteração gordurosa quanto o edema celular, aparecem à microscopia de luz como vacúolos claros, citoplasmáticos, pequenos ou grandes.

Para que haja a morte celular, é necessário que ocorra um dos seguintes eventos: ruptura da membrana celular; destruição dos mecanismos de respiração aeróbica; bloqueio da síntese de proteína; destruição do aparelho genético da célula. E, as funções metabólicas e os elementos estruturais são tão intimamente interligados na célula que qualquer que seja o ponto de ataque as alterações se propagam e afetam outras funções e elementos (Robbins et al., 1986; Vizioli, 1996), .

\subsubsection{Estudo histológico}

As alterações moleculares e funcionais sempre precedem e induzem alterações morfológicas. O lapso de tempo necessário para produzir as alterações reconhecíveis de adaptação, lesão e morte celular varia com a capacidade discriminatória dos métodos utilizados. Com técnicas histoquímicas e ultraestruturais as alterações podem ser observadas em minutos ou horas, porém o tempo poderá ser muito maior, antes de tornarem-se evidentes através da microscopia de luz (Robbins et al., 1986).

Segundo Junqueira (1990), para estudos histológicos, se deseja levar ao microscópio um preparado no qual os tecidos estejam perfeitamente preservados, apresentando estrutura e composição química iguais àquelas que possuíam quando vivos, a fim de minimizar ao máximo a presença de artefatos. 
Conforme o objetivo do estudo, visando preservar a morfologia e composição original, é necessário submeter as peças histológicas a um tratamento prévio, a microtomia, que é composto das seguintes etapas: fixação, desidratação, diafanização, embebição e inclusão (Pacheco, 1981).

A maioria dos tecidos é incolor, assim, para facilitar a visualização das estruturas do tecido, torna-se necessário a coloração destes, de modo que seus componentes tornem-se visíveis e identificáveis. Entre diversos métodos usados, a coloração dupla pela hematoxilina e pela eosina é a mais utilizada em histologia (Junqueira, 1990). 


\section{VIABILIDADE DE CÉLULAS DE LEVEDURAS EM GRÃOS DE MILHO ARMAZENADOS}

\section{Resumo}

O estudo da capacidade das células de leveduras de permanecerem viáveis em grãos, durante um determinado tempo de armazenamento é de extrema importância, advindo do fato de que essa informação é fundamental para o estudo de veículos para a levedura - Saccharomyces cerevisiae - quando o objetivo for aplicá-la como um probiótico.

Esta pesquisa teve por objetivo o estudo da viabilidade de células da levedura, S. cerevisiae, quando aplicadas em grãos de milho para armazenamento e a possibilidade de utilizar os grãos de milho como veículo para a levedura como um probiótico.

Este experimento foi realizado em escala piloto de bancada, montado em um esquema fatorial $2 \times 2 \times 5$, a saber: duas concentrações de inóculos (1 e 2\%); substrato (milho) com dois teores de umidade (16 e 20\%); cinco períodos de armazenamento $(0,15,30,90$ e 110 dias após a instalação). Para conduzir a investigação foram estabelecidos 4 tratamentos, T1 (concentração de 1\% de levedura aplicado sobre substrato com $16 \%$ de umidade); T2 (concentração de $2 \%$ de levedura aplicada sobre substrato com $16 \%$ de umidade); T3 (concentração de $1 \%$ de levedura aplicada sobre substrato com $20 \%$ de umidade); T4 (concentração de $2 \%$ de levedura aplicada sobre substrato com $20 \%$ de umidade). Como veículo de aplicação foi usada uma solução de sacarose $0,5 \%\left(\mathrm{p} \mathrm{p}^{-1}\right)$. A determinação da viabilidade celular foi realizada em todos os 
períodos supracitados. Para tal, foi utilizado o método de coloração com azul de metileno desenvolvido por Pierce (1970).

Os resultados obtidos demonstraram que nos tratamento T1 e T2, as médias de viabilidades encontradas foram de 84,27 e $84,90 \%$, respectivamente, as quais não diferiram estatisticamente entre si. Nos tratatamentos T3 e T4, as médias de viabilidade foram 87,16 e 76,93, respectivamente, de modo que diferiram estatisticamente entre si; o tratamento T3 apresentou médias de viabilidade mais elevada do que o tratamento T4.

As análises da influência de diferentes teores de umidade sobre a viabilidade celular demonstraram que os tratamentos conduzidos nos substratos com $16 \%$ de umidade apresentaram médias de viabilidade de $85,58 \%$ ao passo que os tratamentos conduzidos nos substratos com 20\% de umidade apresentaram médias de viabilidade de 82,04\%. Estas médias diferiram estatisticamente entre si.

As médias de viabilidade das células de leveduras no decorrer dos cinco períodos de avaliação foram os seguintes: 93,91\%; 90,56\%; 89,10\%; 74,74\% e 70,74\%, aos $0,15,30,90$ e 110 dias de tratamento, respectivamente. Pela análise estatística, os resultados dos três primeiros períodos não diferiram entre si, contudo, são superiores aqueles dos dois últimos, os quais não diferiram entre si.

Conclue-se que, a concentração de células aplicadas nos grãos de milho não influencia na viabilidade das células de leveduras durante o armazenamento; a umidade do substrato interfere no desenvolvimento da viabilidade, e que, o nível mais elevado de umidade promove maior mortalidade das células durante $\mathrm{o}$ armazenamento; $\mathrm{a}$ viabilidade celular das leveduras permanece constante durante 30 dias de armazenamento e, que após 90 dias sofre diminuição; as leveduras apresentam viabilidade celular aos 110 dias armazenadas em grãos de milho. A técnica da aplicação da levedura nos grãos de milho armazenados visando a sua utilização como probiótico pode ser empregada. 


\section{VIABILITY OF YEASTS CELLS APPLIED IN STORED CORN GRAINS}

\section{Summary}

The study of the capacity of the yeasts cells remain viable on grains for a certain time of storage is of extreme importance, due to the fact that this information is fundamental to the study of vehicles for the yeast-Saccharomyces cerevisiae - when the objective is to apply it as a probiotic.

This research had as objective the study viability of cells of yeasts, S. cerevisiae, when applied in corn grains for storage, with differents moistures contents, and the possibily to use the corn as vehicle to live yeast as a probiotic.

This work was conduced in pilot scale, in mounted experiment in a factorial outline $2 \times 2 \times 5$, viz: two concentrations of yeasts (1 and $2 \%$ ); substrates (corn) with two moisture teors (16 and 20\%); five storage periods (0,15, 30, 90 and 110 days after the installation). To lead the investigation 4 treatments were established, which were: T1 (concentration of $1 \%$ of yeast applied on substrates with $16 \%$ of moisture); T2 (concentration of $2 \%$ of yeast applied on substrates with $16 \%$ of moisture); T3 (concentration of $1 \%$ of yeast applied on substrates with $20 \%$ of moisture); T4 (concentration of $2 \%$ of yeast applied on substrates with $20 \%$ of moisture). As application vehicle a sucrose solution $0.5 \%\left(\mathrm{w} \mathrm{w}^{-1}\right)$ was used. The determination of the cellular viability was accomplished in all the above-mentioned periods, immediately after the collection. For such the coloration method was used with metilen blue developed by Pierce (1970).

The obtained results demonstrated that in T1 and T2 treatments, the averages of viabilities found in the whole study were of 84.27 and $84.90 \%$, respectively. Which statistically did not differed among them. In the treatments T3 and T4, the viability averages during the whole experiment was 87.16 and $76.93 \%$, respectively. So that they differed statistically among them, presenting T3 larger viability averages than T4.

The analyses of the influence of different moisture contents about the cellular viability, demonstrated that the treatments led on substrate with $16 \%$ of moisture 
presented averages of viability of $85.58 \%$ while the treatments led on substrate with $20 \%$ of moisture presented averages of viability of $82.04 \%$. These averages differed statistically among them.

The averages of viability of the cells of yeasts in elapsing of the five evaluation periods were: $93.91 \%$; $90.56 \% ; 89.10 \% ; 74.74 \%$ and $70.74 \%$, to the $0,15,30,90$ and 110 days after the installation, respectively. For the statistical analysis, the results of the first 3 periods did not differed among them, however, they were superior to those of the last two periods, which did not differ among them.

In conclusion, this study demonstred that the applied yeast concentration does not influence on the viability of yeasts cells during the storage; the moisture of the substrates interferes in the cellular viability during the storage, and that, the highest teors of moisture promotes larger mortality of the cells during the storage; the cellular viability of the yeasts remains constant during about 30 days in storage and, that after 90 days suffers decrease; the cells of yeast present viability until 110 days in storage in corn grains storage; the technique of the application of the live yeast in the corn grains for storage aiming its application as probiotic can be used.

\subsection{Introdução}

A busca por produtos biologicamente ativos, a serem fornecidos aos seres vivos, vem aumentando nos últimos anos. Tal fato decorre da existência de uma preocupação cada vez maior em reduzir o uso de alguns produtos, como os antibióticos, e ao mesmo tempo, da necessidade do desenvolvimento de outros ativos que possam substituí-los. Uma alternativa para a obtenção de produtos sucedâneos é a elaboração de substâncias que atuem de maneira harmônica, levando a um equilíbrio total, o que pode ser encontrado em probióticos. Estes são fornecidos ao indivíduo sob forma de células viáveis, que ao alcançarem o trato gastrointestinal realizam um reequilíbrio da microflora ali existente, com melhor aproveitamento do alimento, quer pelo 
fornecimento de metabólitos essenciais, quer pela complexação de toxinas ou de seus agentes promotores (Fuller et al., 1992).

Com o intuito de se desenvolver um probiótico com características desejáveis às condições do país, a levedura Saccharomyces cerevisiae, é um microrganismo que apresenta grande valor, principalmente, para a economia do Estado e Regional, uma vez que esta representa um dos principais "subprodutos" da indústria sucro-alcooleira no Brasil. Este especial interesse é devido a enorme capacidade instalada de produção que, segundo informações do setor, estima-se em œrca de 300.000 toneladas por ano (Butolo, 1997).

A aplicação da levedura como aditivo na alimentação já vem sendo difundida nos países mais desenvolvidos (Machado, 1997). Contudo, uma dificuldade ainda existente diz respeito à sua aplicação e às técnicas até então desenvolvidas, que recomendam sua incorporação ao alimento apenas momentos antes do seu fornecimento. Este fato pode dificultar a sua difusão e aplicação, pela necessidade de se elaborar a dieta a poucos instantes do consumo.

$\mathrm{Na}$ tentativa de contornar esta situação, foi realizada esta investigação, buscando pesquisar a viabilidade das células da levedura - Saccharomyces cerevisiae quando aplicada em grãos de milho destinados ao armazenamento. Afinal esta é uma informação básica e fundamental para o desenvolvimento de técnicas visando a utilização deste produto como um probiótico e com o objetivo de investigar a possibilidade de impregnar a matéria-prima e a capacidade de permanência das células vivas por um período determinado de armazenamento, até a sua utilização.

Para a condução desta pesquisa foram levados em consideração alguns parâmetros que poderiam influenciar na viabilidade celular. Contudo, pela natureza e caráter pioneiro da pesquisa, com carência de informações na literatura, foi analisada apenas a tendência da viabilidade das células de leveduras, quando aplicadas em grãos de milho armazenados, sem entrar nos méritos de possíveis mecanismos ligados ao microrganismo que possam ter interferido nos resultados obtidos, o que pela complexidade das variáveis envolvidas, certamente se tornaria fora dos objetivos deste estudo. 
Esta investigação teve o objetivo de pesquisar a viabilidade das células de leveduras quando aplicadas em grãos de milho armazenados sob diferentes teores de umidade e a possibilidade de utilizar os grãos de milho como veículo para a levedura como um probiótico.

\subsection{Material e Métodos}

A investigação foi conduzida no Laboratório de Microbiologia - Setor de

Açúcar e Álcool, do Departamento de Agroindústria, Alimentos e Nutrição, da Escola Superior de Agricultura "Luiz de Queiroz", Universidade de São Paulo, em Piracicaba/SP.

\subsubsection{Microrganismo}

Foi utilizada a levedura Saccharomyces cerevisiae desidratada viva, linhagem Y904, desenvolvida em caldo de cana e seca por processo de extrusão, apresentando 93\% de matéria seca, $98 \%$ de viabilidade, $(11,61 \%)$ de trealose, $(12,21 \%)$ de glicogênio e validade até 12/01/2001, procedente da Mauri do Brasil.

\subsection{2 "Substrato" - milho}

Foram utilizados grãos de milho da safra 1998/1999, obtidos no comércio local. O substrato foi caracterizado pela análise de umidade conforme o item 3.4.

\subsection{3 "Solução de Azul de metileno" 0,1\%, descrito por Pierce (1970), utilizada para avaliação da viabilidade das células de leveduras.}

Azul de metileno

Citrato de sódio

Água destilada

Foi realizada a pesagem de 0,02 grama de azul de metileno em balança analítica. Transferindo-o para um erlenmeyer e adicionando $20 \mathrm{~mL}$ de água e 4 gramas de citrato de sódio. 


\subsubsection{Determinação da umidade}

A determinação da umidade foi feita por gravimetria de acordo com Brasil (1992).

\subsubsection{Condução do experimento}

Para a realização deste ensaio, foi utilizado o milho como hospedeiro para o crescimento destes microrganismos, o qual foi acondicionado em microssilos plásticos herméticos, com capacidade para 2,5 litros.

As análises de viabilidade foram realizadas para cada período de amostragem experimental (aos 0, 15, 30, 90 e 110 dias decorrida a aplicação).

\subsubsection{Preparo do substrato}

O substrato foi umidecido para atingir teores de umidade próximos de $16 \%$ e $20 \%$, em função de simular situações que podem ocorrer na massa de grãos armazenada em silos. Para tanto, a água foi pulverizada sobre os grãos, nas quantidades necessárias para cada teor de umidade desejado, e aguardado um período de 24 horas, o suficiente para que o substrato pudesse absorver toda a água adicionada.

Em seguida, foi aplicada ao substrato uma solução de sacarose $0,5 \%$ (p. $\mathrm{p}^{-1}$ ), que teve por objetivo servir de veículo de adesão e alimento para as leveduras.

\subsubsection{Inoculação das leveduras}

A inoculação das leveduras desidratadas vivas, foi efetuada pela aplicação de células viáveis, nas concentrações desejadas para cada tratamento, e para uma uniforme e homogênea distribuição das células foi utilizado um "mini tambor rotatório".

\subsubsection{Condução do armazenamento}

Após a inoculação, o substrato foi acondicionado em microssilos plásticos com tampas vedadas com borracha de silicone. Então foram incubados até o momento da coleta das amostras e realização das análises. 
O experimento foi mantido por cinco períodos, a saber: aos 0, 15, 30, 90 e 110 dias após a inoculação. Para cada período de coleta de dados foram instalados tratamentos com 4 repetições cada. Após cada coleta das amostras, o material analisado fora retirado do experimento e mantido a temperatura de -10 a $-4^{\circ} \mathrm{C}$ até o final do ensaio.

\subsubsection{Determinação da viabilidade das células de leveduras}

Para esta determinação, foi realizada a coleta de amostras de $5 \mathrm{~g}$ de substrato para cada repetição; nestas amostras, foram executadas lavagens superficiais com solução de água peptonada a 0,1\%, conforme Silva et al (1997). Após a lavagem, foi procedida a diluição necessária para a realização dos testes de viabilidade. Na ocasião, foi considerado como adequadas as diluições que permitiram observar ao microscópio em aumento de 400 vezes, de 40 a 60 células.

A viabilidade das células de leveduras foi determinada pela técnica de coloração com azul de metileno $(0,1 \%)$ de acordo com Pierce (1970).

\subsubsection{Análise estatística}

Quadro 1 - Descrição dos tratamentos utilizados no estudo .

\begin{tabular}{|r|l|c|}
\hline \hline Tratamentos & \multicolumn{1}{|c|}{ Descrição } & Repetições \\
\hline T1 & Milho com 16\% de umidade+ 1,0\% de levedura Y904 & 4 \\
T2 & Milho com 16\% de umidade +2,0\% de levedura Y904 & 4 \\
T3 & Milho com 20\% de umidade + 1,0\% de levedura Y904 & 4 \\
T4 & Milho com 20\% de umidade + 2,0\% de levedura Y904 & 4 \\
\hline \hline
\end{tabular}

O delineamento experimental utilizado foi um arranjo fatorial de $2 \times 2 \times 5$, distribuídos inteiramente ao acaso, com 4 repetições para cada tratamento, sendo duas concentrações de leveduras, substratos com dois teores de umidade e 5 períodos de armazenamento, totalizando 80 unidades de observação no total do experimento. 
Quadro 2 - Esquema da análise da variância utilizado no estudo

\begin{tabular}{|ll|}
\hline \hline CAUSAS DE VARIAÇÃO & GL \\
\hline Concentração de levedura & 1 \\
Umidade & 1 \\
Período & 4 \\
Umidade x tratamento & 1 \\
Umidade x período & 4 \\
Tratamento x período & 4 \\
Umidade x tratamento x período & 4 \\
Resíduo & 60 \\
\hline Total & 79 \\
\hline
\end{tabular}

Os resultados obtidos foram submetidos ao teste de análise da variância (ANOVA), e ao teste de comparação de médias de Tukey, ao nível de 0,05 de probabilidade. Para o desenvolvimento dos cálculos e reprodução de valores foi utilizado o sistema computacional para análise estatística "SANEST".

\subsection{Resultados e discussão}

Pela análise da variância (Tabela 1) pode ser verificado que as médias de viabilidade dos diferentes tratamentos, envolvendo os fatores concentrações de leveduras, teores de umidade e períodos de estocagem, apresentam diferenças entre si, indicando que os tratamentos investigados exerceram influência sobre a variável estudada (viabilidade) sob as condições que foram conduzidos os estudos, demonstrando a necessidade de aplicação do Teste de Comparação de Médias. 
Tabela 1 - Análise da variância das médias dos tratamentos

\begin{tabular}{lrrrrl}
\hline \hline CAUSAS DA VARIAÇÃO & G.L. & S.Q. & Q.M. & VALOR F & PROB.>F \\
\hline LEVEDURA & 1 & 673,71 & 673,71 & 26,52 & 0,00003 \\
UMIDADE & 1 & 250,47 & 250,47 & 9,86 & 0,00296 \\
PERÍODOS & 4 & 6860,84 & 1715,21 & 67,51 & 0,00001 \\
LEV*UMI & 1 & 392,51 & 392,51 & 15,45 & 0,00045 \\
LEV*EPO & 4 & 430,87 & 107,71 & 4,24 & 0,00464 \\
UMI*EPO $^{*}$ LEV & 4 & 1085,84 & 271,46 & 10,68 & 0,00002 \\
LESINEPO & 4 & 634,56 & 158,64 & 6,24 & 0,00049 \\
RESIDUO & 60 & 1524,41 & 25,40 & & \\
\hline \hline
\end{tabular}

TOTAL

7911853,25

MEDIA GERAL $=83,81 \%$

COEFICIENTE DE VARIAÇÃO $=6,0 \%$

\subsubsection{Influência da aplicação de diferentes concentrações de leveduras na viabilidade celular}

Nos tratamentos em substratos com teor de $16 \%$ de umidade, não foram verificadas diferenças estatísticas entre os tratamentos contendo concentrações $1 \%$ e $2 \%$ de levedura (Tabela 2). Isto pode ter ocorrido devido ao fato que nos tratamentos sob estas condições, as leveduras tenham sofrido pouca competição com outros agentes biológicos, principalmente microrganismos, de modo que a capacidade de permanecerem viáveis não foi afetada, apresentando valores de viabilidade semelhantes para os tratamentos nas duas concentrações de leveduras aplicadas.

Para os substratos com $20 \%$ de umidade, os tratamentos contendo $1 \%$ de levedura apresentaram maiores médias de viabilidade do que os tratamentos contendo $2 \%$ de levedura (Tabela 2). Contudo, estes resultados quando comparados com aqueles dos tratamentos com $16 \%$ de umidade, permitiram observar que estas diferenças não podiam ser atribuídas às concentrações de leveduras aplicadas e, sim a outro fator, o qual parece ter sido a umidade. Esta pode ter propiciado o desenvolvimento mais rápido 
de outros microrganismos, dificultando a adaptação de um número maior de células de leveduras, portanto, refletindo em maior mortalidade de células que pode ser interpretado pelo menor percentual de viabilidade celular com concentração de $2 \%$ quando comparado aos tratamentos com concentração de $1 \%$.

Tabela 2 - Viabilidade, em percentagem, das células de leveduras quando aplicadas em concentrações de 1 e $2 \%$ sobre substratos com teores finais de umidade de $16 \%$ e $20 \%$, respectivamente.

\begin{tabular}{|c|c|c|c|c|}
\hline Tratamentos & $\mathrm{N}^{\mathrm{o}}$ de repetições & teor de umidade & Médias & Tukey 5\% \\
\hline Concentração $1 \%$ & 20 & $16 \%$ & 86,27 & $\mathrm{a}$ \\
\hline Concentração $2 \%$ & 20 & $16 \%$ & 84,90 & $\mathrm{a}$ \\
\hline Concentração $1 \%$ & 20 & $20 \%$ & 87,16 & $\mathrm{a}$ \\
\hline Concentração $2 \%$ & 20 & $20 \%$ & 76,93 & $\mathrm{~b}$ \\
\hline
\end{tabular}

Médias seguidas por letras distintas diferem entre si ao nível de significância de 5\%, perante ao Teste de Tukey.

\subsubsection{Comportamento celular em tratamentos com concentrações de 1 e 2\% de leveduras em diferentes períodos de armazenamento}

Ambos os tratamentos, com concentrações de 1 e $2 \%$ leveduras, apresentaram médias de viabilidade celular semelhantes, logo após a instalação do ensaio, não diferindo estatisticamente entre si (Tabela 3). Isto significa que o método utilizado para a aplicação foi eficaz e que proporcionou uma boa homogeneidade, não interferindo nos resultados obtidos. Por outro lado, a fonte de leveduras utilizada no estudo foi obtida de um processo otimizado e com bom controle de qualidade do produto final. Além disso, a fonte utilizada apresentava elevada taxa de viabilidade celular, superior a $93 \%$ em todos os casos.

Ao analisar os resultados encontrados no Período2 (Tabela 3), pode ser observado que os tratamentos com as concentrações de 1 e $2 \%$ de leveduras não diferiram estatisticamente entre si após 15 dias do início do ensaio. Além disso, pode 
ser verificado que valores de viabilidade encontrados, 88,62 e 92,59\%, para as concentrações de 1 e $2 \%$ respectivamente, são ótimos, indicando que a viabilidade celular permanece praticamente estável por 15 dias, quando aplicadas em grãos de milho para armazenamento. Estes resultados confirmam aqueles obtidos por Petterson \& Schnürer (1995), que citam que as leveduras quando aplicadas em grãos de trigo apresentavam alta viabilidade, após um certo período.

Tabela 3 - Viabilidade das células de leveduras, em percentagem, durante o período experimental ( aos dias 0, 15, 30, 90 e 110 após o início do estudo).

\begin{tabular}{lcccccc}
\hline \hline & & \multicolumn{5}{c}{ Tempo em dias } \\
\cline { 3 - 7 } Tratamentos & $\mathrm{N}^{\mathrm{o}}$ de & Período1 & Período2 & Período3 & Período4 & Período5 \\
& repetições & 0 & 15 & 30 & 90 & 110 \\
\hline Concentração 1\% & 8 & $93,55 \mathrm{a}$ & $92,53 \mathrm{a}$ & $91,52 \mathrm{a}$ & $78,55 \mathrm{a}$ & $77,43 \mathrm{a}$ \\
Concentração 2\% & 8 & $94,28 \mathrm{a}$ & $88,60 \mathrm{a}$ & $86,69 \mathrm{a}$ & $70,93 \mathrm{~b}$ & $64,05 \mathrm{~b}$ \\
\hline
\end{tabular}

Médias seguidas por letras distintas, na mesma coluna, diferem entre si ao nível de significância de 5\%, perante ao Teste de Tukey (Comparação entre linhas).

Após 30 dias da aplicação (Período3), os tratamentos com as diferentes concentrações de leveduras não apresentaram diferenças estatísticas entre si para a variável viabilidade celular. Ademais, outro aspecto importante que pode ser observado foi que após 30 dias da aplicação foram verificadas médias de viabilidade de 91,52\% e $86,69 \%$ (Tabela 3) para os tratamentos com concentrações de $1 \%$ e $2 \%$ de leveduras, respectivamente. Resultados semelhantes com aqueles encontrados logo após a instalação do experimento (Período1 - Tabela 3). Estes resultados concordam com os obtidos por Baptista et al (1999), quando observaram as células de leveduras apresentavam viabilidade praticamente ínalterada $\operatorname{dos} 10$ aos 30 dias em armazenamento.

Ocorreram diferenças estatísticas nas médias das viabilidades das células das leveduras, entre tratamentos com concentrações de 1 e $2 \%$ após 90 dias de armazenamento (Período4). Essas diferenças podem ser atribuídas à interferência de fatores como a umidade que podem ser observados na Tabela 4. As células de leveduras inoculadas em substratos com $20 \%$ de umidade apresentaram médias de viabilidade menores do que aquelas inoculadas em substratos com $16 \%$ de umidade. Isto pode ser 
atribuído a agentes competidores, conforme já discutido anteriormente (resultados da Tabela 2).

Decorridos 110 dias em armazenamento, as células de leveduras nos tratamentos contendo concentrações de $1 \%$ apresentaram médias de viabilidade maiores do que os tratamentos contendo concentrações de $2 \%$ (Tabela 3). Isso leva a crer que as concentrações de leveduras exercem influência na viabilidade, contudo, analisando novamente a Tabela 2, pode ser observado que não foram encontradas diferenças na viabilidade para as duas diferentes concentrações de leveduras aplicadas em substratos com $16 \%$ de umidade. Então, estas diferenças de resultados podem ser atribuídas à influência da umidade sobre a viabilidade.

\subsubsection{Efeito da umidade do substrato sobre a viabilidade celular de leveduras durante $o$ armazenamento.}

Nos tratamentos conduzidos sobre substratos com teores de 16 e $20 \%$ de umidade, pode ser verificado que aqueles realizados sobre substratos com menores teores de umidade apresentaram maiores médias de viabilidade quando comparados aqueles aplicados em substratos com maiores teores de umidade. Isto pode ser explicado conforme discutido anteriormente na Tabela 2.

Tabela 4 - Influência de diferentes teores de umidade no substrato , 16 e 20\%, sobre a viabilidade das células de leveduras.

\begin{tabular}{lccc}
\hline \hline Tratamentos & No de repetições & Médias (\%) & Teste de Tukey 5\% \\
\hline 16\% UMIDADE & 40 & 85,58 & $\mathrm{a}$ \\
$20 \%$ UMIDADE & 40 & 82,04 & $\mathrm{~b}$ \\
\hline
\end{tabular}

Médias seguidas por letras distintas diferem entre si ao nível de significância de 5\%.

Para os tratamentos que foram inoculados $1 \%$ de levedura (Tabela 5), pode ser verificado que as médias de viabilidade não diferiram entre si, estatisticamente, quando aplicadas em substratos com 16 e $20 \%$ de umidade. Isso pode ter ocorrido porque ao 
aplicar $1 \%$ de levedura em substrato com $20 \%$ de umidade, mesmo com o crescimento de outros microrganismos, as condições de restrição de espaço sofridas não foram tão rígidas a ponto de afetar a viabilidade das células. Hipoteticamente, outra situação que pode ter contribuído para isso, é o fato de que a solução de sacarose aplicada como veículo pode servir como uma fonte energética à levedura e, que esta fonte não tenha sido esgotada durante o período experimental, podendo ter contribuído com a manutenção da viabilidade, quando da aplicação de $1 \%$ de levedura nas duas condições de umidade do ensaio. Por outro lado, as médias de viabilidade das células de leveduras nos tratamentos com concentração de $2 \%$ de leveduras foram maiores nos tratamentos realizados sobre substratos que apresentavam 16\% de umidade quando comparadas com aquelas dos tratamentos realizados sobre substratos com $20 \%$ de umidade (Tabela 5), uma vez conhecido que, os volumes de sacarose aplicados foram os mesmos para as duas condições (concentrações de 1 e $2 \%$ de leveduras), é possível que tenha ocorrido o esgotamento desta fonte mais precocemente nos tratamentos com maior número de células, no caso, concentração de $2 \%$ de levedura. Em acordo com Crowe et al. (1998), a quantidade de dissacarídeo disponível para a célula pode permitir que esta sobreviva por um período maior ou menor, em condições adversas. Afirmação esta, reforçada por Diniz-Mendez et al. (1999), que citam a sacarose como uma substância que pode prevenir ou reduzir os efeitos adversos sobre a viabilidade de leveduras. Além disso, conforme já foram discutidos nos dados da Tabela 2, a interferência de microrganismos também podem ter colaborado para este comportamento.

Tabela 5 - Influência da aplicação de concentrações de 1 e $2 \%$ de leveduras em substratos com 16 e $20 \%$ de umidade sobre a viabilidade (médias em percentagem) das células de leveduras.

\begin{tabular}{lccc}
\hline \hline Tratamentos & No de repetições & 1\% de leveduras & $2 \%$ de leveduras \\
\hline $16 \%$ UMIDADE & 20 & $86,27 \mathrm{a}$ & $84,89 \mathrm{a}$ \\
$20 \%$ UMIDADE & 20 & $87,16 \mathrm{a}$ & $76,92 \mathrm{~b}$ \\
\hline
\end{tabular}

Médias seguidas por letras distintas, na mesma coluna, diferem entre si ao nível de significância de $5 \%$, perante ao Teste de Tukey. 


\subsubsection{Efeito do período de estocagem na viabilidade das células de leveduras}

Observando a Figura 1, pode ser verificado que nos três primeiros períodos de estocagem a viabilidade das células das leveduras não foi alterada, de modo que permaneceu praticamente constante. Contudo, nos períodos 4 e 5 as médias de viabilidade apresentaram quedas, quando comparadas com as médias dos períodos iniciais. Isto significa que, ao serem aplicadas em grãos para armazenamento, as células de leveduras apresentaram viabilidade estável até os 30 dias e que após 90 dias sofreram reduções na viabilidade. Entretanto, nos períodos 4 e 5 não foram verificadas diferenças entre as médias de viabilidade. Por outro lado, embora tenham sido observadas reduções nos percentuais de células viáveis, estas ainda apresentaram um valor de viabilidade considerado alto ao término da investigação.

Uma hipótese que poderia explicar tal comportamento da viabilidade, pode ser o fato de que durante o armazenamento tenha ocorrido o esgotamento de carboidratos de reservas que estavam mantendo a integridade de membrana celular e, assim sendo, permitindo a manutenção da viabilidade; isto estaria em acordo com Leslie et al. (1994), que observaram uma clara relação entre a quantidade de trealose em células viáveis de $\mathrm{S}$. cerevisiae e a sua habilidade em tolerar armazenamento.

Nos tratamentos com concentração de $1 \%$ de levedura, as médias de viabilidade das mesmas não diferiram estatisticamente entre si nos três primeiros períodos (Tabela 6). Contudo, podem ser verificadas reduções nas percentagens de células viáveis quando comparadas às percentagens de médias obtidas nos três primeiros períodos com aquelas encontradas nos dois últimos períodos (4 e 5).

Estes resultados indicam que com o passar do tempo ocorreram modificações ambientais e na biologia das células das leveduras que promoveram mortalidade das mesmas. Concomitantemente, pode ser verificado que os possíveis fatores que possam ter interferido, propiciaram uma queda lenta e gradativa, de modo que, decorridos 110 dias de incubação as leveduras apresentaram viabilidade acima de $75 \%$. 

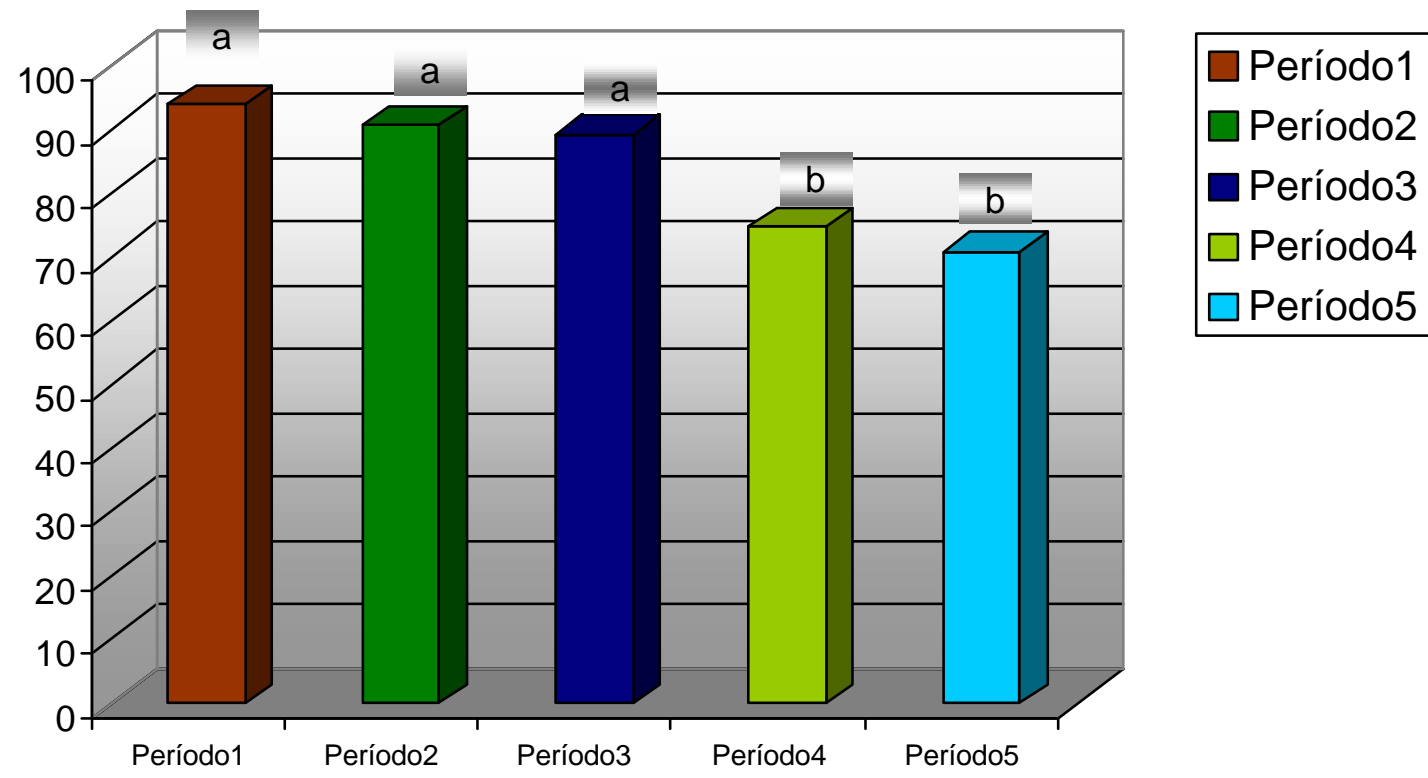

Letras distintas diferem entre si, estatísticamente, ao nível de significância de $5 \%$, perante ao Teste de Tukey.

Figura 1 - Viabilidade das células de leveduras durante a investigação.

Tabela 6 - Viabilidade, em percentagem, para os tratamentos com concentrações de $1 \%$ e $2 \%$ de leveduras durante todo o experimento.

\begin{tabular}{lccc}
\hline \hline Tratamentos & $\mathrm{N}^{\mathrm{o}}$ de repetições & $1 \%$ de Leveduras & $2 \%$ de Leveduras \\
\hline Início & 8 & $93,55 \mathrm{a}$ & $94,28 \mathrm{a}$ \\
15 dias & 8 & $92,53 \mathrm{a}$ & $88,60 \mathrm{ab}$ \\
30 dias & 8 & $91,52 \mathrm{a}$ & $86,69 \mathrm{~b}$ \\
90 dias & 8 & $78,55 \mathrm{~b}$ & $70,93 \mathrm{c}$ \\
110 dias & 8 & $77,43 \mathrm{~b}$ & $64,05 \mathrm{c}$ \\
\hline
\end{tabular}

Médias seguidas por letras distintas, na mesma coluna, diferem entre si ao nível de significância de $5 \%$, perante ao Teste de Tukey.

Nos tratamentos com concentração de $2 \%$ de levedura, as médias de viabilidade celular não diferiram estatisticamente nos dois primeiros períodos (início e 15 dias, respectivamente). Entretanto, foram observadas médias de viabilidade maiores 
nos períodos 1 e 2 quando comparadas com as médias dos períodos 4 e 5 (90 e 110 dias, respectivamente). Além disso, foram observadas que as médias de viabilidade no período 3 (30 dias) foram inferiores àquelas observadas na período 1, contudo, não diferiram daquelas do período 2 e foram superiores àquelas encontradas nos períodos 4 e 5.

As médias de viabilidade encontradas após os 30 dias em armazenamento podem ser consideradas excelentes, permanecendo próximas àquelas obtidas no início do estudo. Após 90 dias em armazenamento, as médias de viabilidade encontradas também foram satisfatórias, com mais de $70 \%$ de células viáveis. Após 110 dias em armazenamento, foram verificadas médias de viabilidade próximas a 65\%, que podem ser consideradas muito boas se forem ponderadas as condições de armazenamento e sobretudo porque existiam outros microrganismos que certamente concorreram pelas condições de sobrevivência, e, ao fato de que as leveduras utilizadas na experiência, Saccharomyces cerevisiae, não serem relatadas como habitantes naturais do substrato em estudo.

\subsection{Conclusões}

1. A inoculação de leveduras em grãos de milho armazenados, visando a sua utilização como probiótico, é uma técnica viável.

2. A concentração de células aplicadas nos grãos de milho para armazenamento não influencia na viabilidade das células de leveduras durante o armazenamento;

3. A umidade do substrato no momento em que é realizada a inoculação das leveduras interfere na capacidade das células quanto a permanecerem viáveis durante o armazenamento, de modo que, substratos com teores de umidade 
elevados tendem a promover maior mortalidade das células durante $\mathrm{o}$ armazenamento;

4. A viabilidade celular das leveduras permanece constante durante 30 dias de armazenamento; após 90 dias de estocagem há redução no número de células viáveis da ordem de $30 \%$.

5. As leveduras apresentam viabilidade celular até 110 dias de armazenamento em grãos de milho; não necessita, portanto, de aplicação imediata como poderia se esperar para um probiótico. 


\section{Saccharomyces cerevisiae E COMPONENTES DA SUA PAREDE CELULAR NA REDUÇÃO DE AFLATOXICOSES}

\section{Resumo}

Investigações envolvendo Saccharomyces cerevisiae indicam que suas células vivas e componentes da parede celular desta levedura podem suprimir os efeitos promovidos pelas aflatoxinas. Estas toxinas, por sua vez, proporcionam grandes prejuízos à economia do país e à saúde da população. Devido a esses motivos, foi conduzida esta pesquisa com o propósito de investigar a capacidade de reduzir os efeitos promovidos pelas aflatoxinas, em animais de laboratório, da Saccharomyces cerevisiae viva, termolisada e de componentes da sua parede celular.

Para a execução deste estudo foi realizado um bioensaio, em arranjo inteiramente casualisado, utilizando ratos albinos (Rattus norvegicus) da linhagem Wistar. Estes animais foram distribuídos em sete lotes de cinco ratos cada, os quais foram submetidos aos seguintes tratamentos: (T1) dieta a base de caseína; (T2) dieta padrão para ratos contaminada com $400 \mu \mathrm{g} \cdot \mathrm{kg}^{-1}$ de aflatoxinas; (T3) dieta padrão para ratos contaminada com $400 \mu \mathrm{g} \cdot \mathrm{kg}^{-1}$ de aflatoxinas $+0,1 \%$ de Mycosorb ${ }^{\circledR}$; (T4) dieta padrão para ratos contaminada com $400 \mu \mathrm{g} \cdot \mathrm{kg}^{-1}$ de aflatoxinas $+0,2 \%$ de Mycosorb ${ }^{\circledR}$; (T5) dieta padrão para ratos contaminada com $400 \mu \mathrm{g} \cdot \mathrm{kg}^{-1}$ de aflatoxinas $+1 \%$ de levedura desidratada viva; (T6) dieta padrão para ratos contaminada com $400 \mu{\mathrm{g} . \mathrm{kg}^{-1} \mathrm{de}}^{-1}$ aflatoxinas $+1 \%$ de levedura termolisada; (T7) dieta padrão para ratos $+20 \%$ de amendoim isento de contaminação por micotoxinas. A contaminação das dietas foi realizada pela adição à dieta de $20 \%$ de amendoim contaminado por aflatoxinas.

O ensaio foi conduzido durante 28 dias, após este período, os animais foram mortos. Para avaliar a resposta de cada tratamento foram investigados os seguintes 
parâmetros: consumo médio de alimentos; \% de ganho de peso diário em relação ao peso inicial; peso relativo de órgãos internos e análise histológica do fígado dos animais.

Os resultados demonstraram que os animais submetidos ao T5 apresentaram maior consumo médio do que aqueles do T1 e do T2, não diferindo estatisticamente dos demais tratamentos. A \% de ganho de peso diário em relação ao peso inicial foi maior nos animais submetidos ao T4 quando comparados com aqueles submetidos aosT1, T2 e T7, contudo, não diferindo estatisticamente dos outros tratamentos.

Ao analisar o peso de órgãos internos foi possível verificar que, os pesos relativos dos fígados, corações e rins dos animais submetidos aos diferentes tratamentos não diferiram estatisticamente entre si.

$\mathrm{Na}$ análise histológica, o tecido do hepático de animais submetidos ao T1 foi adotado como padrão de referência isento de toxidez. Em comparação com este, foi verificado que os animais submetidos ao T2 apresentavam sinais claros de hepatoxidez; e, que os animais submetidos ao T3 e T6 apresentavam sintomas dos danos promovidos por aflatoxinas semelhantes ao T2; já os animais que receberam o T4 apresentaram sinais de toxidez maiores do que o controle com aflatoxinas (T2); contudo, os animais conduzidos sob o T5 demonstraram ter grande redução nos danos causados por aflatoxinas em nível de hepatócitos; finalmente, os animais submetidos ao T7 obtiveram comportamentos semelhantes com aqueles que receberam o $\mathrm{T} 1$ quanto a histologia hepática.

Conclue-se que, os tratamentos à base de componentes da parede celular de leveduras e leveduras termolisadas não são capazes de reduzir os danos promovidos por aflatoxinas em nível histológico; as leveduras desidratadas vivas são capazes de reduzir a hepatoxicidez provocada por aflatoxinas. 


\section{Saccharomyces cerevisiae AND COMPONENTS OF ITS CELLULAR WALL IN THE REDUCTION OF AFLATOXICOSIS}

\section{Summary}

Investigations involving Saccharomyces cerevisiae indicate that its live cells and that components its cellular wall can suppress the effects caused by aflatoxins. This toxins, for its time, provide great damages to the economy in the country and to the health of the population. Due to these reasons, was conduced this research with objective of investigate the capability of reduces the effectes promoted by aflatoxins of the S. cerevisiae, live, termolised, and components its of the cellular wall.

For the execution of this study a bioassay was realized, in arrangement entirely casualised, using albincs rats of the strain Winstar. These animals were separated in seven groups of five animals each, which were submitted to the following treatments: (T1) a casein based diet; (T2) standard diet for rats contaminated with $400 \mu \mathrm{gg}_{\mathrm{kg}}{ }^{-1}$ of aflatoxins; (T3) standard diet for rats contaminated with $400 \mu \mathrm{g} \cdot \mathrm{kg}^{-1}$ of aflatoxins + $0.1 \%$ of Mycosorb ${ }^{\circledR}$; (T4) standard diet for rats contaminated with $400 \mu \mathrm{g}^{-\mathrm{kg}^{-1}}$ of aflatoxins $+0.2 \%$ of Mycosorb $^{\circledR}$; (T5) standard diet for rats contaminated with 400 $\mu \mathrm{g} \cdot \mathrm{kg}^{-1}$ of aflatoxins $+1 \%$ of dehydrated live yeast; (T6) standard diet for rats contaminated with $400 \mu \mathrm{g} \mathrm{kg}^{-1}$ of aflatoxins $+1 \%$ of termolised yeast; (T7) basal diet for rats $+20 \%$ of peanut free of contamination for micotoxinas. The contamination of the diets was accomplished by the addition of $20 \%$ of contamined peanut by afaltoxins. This assay was led during 28 days, after this period, the animals were died. To evaluate the effects of each treatment the following parameters were investigated: medium consumption of foods; percentage of gains of daily weight in relation to the initial weight; internal organsre lative weight and histologic analysis of the hepatic tissue of the animals.

The results demonstrated that the animals submitted to T5 presented larger medium consumption than those of $\mathrm{T} 1$ and $\mathrm{T} 2$, not differing statistically from the other 
treatments. The percentage of gains of daily weight in relation to the initial weight was larger in the animals submitted to T4 when compared with those submitted to T1, T2 and $\mathrm{T} 7$, however, not differing statistically from the other treatments.

When analyzed the relative weights internal organs it was possible to verify that, the relative weight of the animals livers submitted to different treatments did not differ statistically among them. The animals submitted to the different treatments presented the heart relative weight similar among them. Besides, that the same behavior was observed for the relative weight of the kidneys of the animals in the different treatments.

For the histologic analysis, the tissue of the liver of animals submitted to T1 was adopted as reference pattern as free of toxicity. In comparison with this, it was verified that the animals submitted to $\mathrm{T} 2$ presented clear signs of hepatoxidz; the animals submitted to T3 also suffered the damages promoted by aflatoxins; the animals that received T4 presented signs of larger toxicity than the control with aflatoxins (T2); however, the animals led under T5 they demonstrated to have great reduction of toxins damages in hepatocits concentration; however, the animals of the group T6 demonstrated that this treatment was not capable of reducing the effects of the aflatoxicosis, behaving similarly to $\mathrm{T} 2$. Finally, the animals submitted to $\mathrm{T} 7$ obtained behaviors similar with those that received $\mathrm{T} 1$.

In conclusion, this study demonstrated that the treatments produced from cellular wall of yeasts and termoliseds yeasts are not capable of reducing the damages promoted by aflatoxins in histologic level; the dehydrated live yeast reduces hepatoxicity caused by aflatoxins.

\subsection{Introdução}

Desde os estudos pioneiros, em microbiologia, conduzidos por Pasteur, envolvendo a levedura, este microrganismo tem sido alvo de inúmeras investigações, e advindo a isto, de um grande número de aplicações. No Brasil, a levedura é utilizada na 
produção de pães, confeitos, etanol e bebidas, gerando mais de 1 milhão de empregos e proporcionando benefícios à economia. Pela magnitude de utilização, a indústria nacional gera, anualmente, um excedente de milhares de toneladas deste importante agente biológico, o que necessita e merece aplicações racionais, a fim de expressar seu potencial e refletir em benefícios à humanidade.

Uma área de conhecimento importante, com reconhecidos méritos pelas suas pesquisas e aplicações envolvendo leveduras é a Ciência de Alimentos, em cuja concepção de utilização destes microrganismos tem tido enormes avanços. Num primeiro momento e durante décadas, foram realizados inúmeros estudos com o emprego da levedura como fonte proteíca. Atualmente, em estágio de maior maturidade, as investigações têm sido conduzidas no sentido de recomendá-la como uma cultura viva, que pode interagir com a microflora intestinal, promovendo um reequilíbrio, através de componentes que podem estimular o crescimento e melhorar o estado salutar do hospedeiro (Leedle, 2000).

Por outro lado, em grãos destinados à alimentação é comum o desenvolvimento de fungos, principalmente espécies dos gêneros Aspergillus e Penicillium, as quais muitas vezes produzem metabólitos secundários, que sendo ingeridos, atuam como toxinas comumente conhecidas como micotoxinas (Lacey \& Magan, 1991).

Entre as toxinas mais comuns e prejudiciais estão as aflatoxinas, encontradas principalmente em grãos armazenados e que, normalmente, são incorporados em dietas destinadas à alimentação humana e animal. Como conseqüência da sua ingestão, em humanos, podem ocorrer doenças graves, como o câncer; e, em animais, podem promover perda de peso, apatia, graves distúrbios fisiológicos e óbito (Heathcote \& Hibbert, 1978).

Inúmeras tentativas de controlar os efeitos nocivos das aflatoxinas já foram realizadas. Entre as tantas, uma corrente científica que tem ganhado importância nos últimos anos, recomenda a aplicação de diferentes produtos provenientes de leveduras para essa finalidade. Os resultados obtidos até então são promissores e assim, torna-se uma necessidade estudos objetivando neutralizar esta toxina utilizando as leveduras que são produzidas em abundância em indústrias do país (Stanely et al., 1993; Spring, 2000). 
Devido a esses motivos, foi conduzida esta pesquisa com o propósito de investigar a capacidade de reduzir os efeitos promovidos pelas aflatoxinas, em animais de laboratório, da Saccharomyces cerevisiae viva, termolisada e de componentes da sua parede celular.

\subsection{Material e Métodos}

A investigação foi conduzida nos Setores de Microbiologia - de Açúcar e Álcool, Micotoxinas e Nutrição Humana, do Departamento de Agroindústria, Alimentos e Nutrição, na Escola Superior de Agricultura "Luiz de Queiroz", Universidade de São Paulo, em Piracicaba/SP e, no Departamento de Diagnóstico Oral, da Faculdade de Odontologia de Piracicaba, Universidade de Campinas, em Piracicaba/SP.

\subsubsection{Microrganismos e componentes celulares utilizados}

a) Levedura da espécie Saccharomyces cerevisiae, linhagem Y1026, aplicada na forma de desidratada viva e, cedida pela Altech do Brasil;

b) Linhagem de Saccharomyces cerevisiae, não caracterizada, empregada na produção de álcool, na forma termolisada, fornecida pela usina "Galo Bravo" - Ribeirão Preto/SP.

c) Mananoligossacarídeos, extraídos da parede celular da levedura S.cerevisiae, linhagem Y1026, com designação comercial de Mycosorb ${ }^{\circledR}$, cedido pela Altech do Brasil.

\subsubsection{Matéria-prima para contaminação das dietas}

O amendoim foi adicionado na elaboração das diferentes dietas com e sem contaminação com aflatoxinas. Foram investigados diferentes lotes de amendoim, sendo escolhido para o estudo aquele com teores mais elevados de aflatoxinas.

Além do material contaminado, foi selecionado um material isento de contaminação por aflatoxinas, que foi utilizado na elaboração da dieta controle (negativo). 


\subsubsection{Composição básica das dietas}

A dieta fornecida aos ratos foi a descrita por Reeves et al. (1993), constituída de proteínas, lipídios, carboidratos, fibras, mistura vitamínica e mistura mineral, conforme apresentado nas Tabelas 7, 8 e 9.

Tabela 7 - Formulação padrão utilizada para composição das dietas no ensaio biológico

\begin{tabular}{lc}
\hline Componentes & $\begin{array}{c}\text { Quantidade } \\
\mathrm{g} \mathrm{kg}^{-1+} \text { de dieta }\end{array}$ \\
\hline Caseína $(\geq 85 \%$ de proteína) & 200,00 \\
Amido de milho & 397,48 \\
Óleo de soja & 70,00 \\
Sacarose & 100,00 \\
Celulose & 50,00 \\
Mistura mineral (AIN-93G-MX) & 35,00 \\
Mistura vitamínica (AIN-93-VX) & 10,00 \\
$\alpha$-cistina & 3,00 \\
Bitarato de colina & 2,50 \\
Tert Butylhidroquinona (TBHq) & 0,014 \\
\hline
\end{tabular}

Fonte: Reeves et al 1993.

Tabela 8 - Mistura Vitamínica (AIN-93VX) adicionada em todas as dietas para o ensaio biológico.

\begin{tabular}{lc}
\hline \hline Vitaminas & $\mathrm{g} \mathrm{kg}^{-1}$ de mistura \\
\hline Ácido Nicotínico & 3,00 \\
Pantotenato de Ca & 1,60 \\
Piridoxina HCl & 0,70 \\
Tiamina HCl & 0,60 \\
Riboflavina & 0,60 \\
Ácido Fólico & 0,20 \\
D-Biotina & 0,02 \\
Vitamina B 12 $_{\text {Vitamina E }}$ & 2,50 \\
Vitamina A (pó) & 15,0 \\
Vitamina D & 0,80 \\
Vitamina K & 0,25 \\
Sacarose & 0,075 \\
\hline \hline
\end{tabular}

Fonte: Reeves et al 1993. 
Tabela 9 - Mistura Mineral (AIN -93G-MX) componentes das dietas preparadas.

\begin{tabular}{lr}
\hline \hline Minerais & $\mathrm{g} \mathrm{kg}^{-1}$ de mistura \\
\hline Carbonato de cálcio anidro & 357,00 \\
Fosfato de Potássio monobásico & 196,00 \\
Citrato de Potássio & 70,78 \\
Cloreto de Sódio & 74,74 \\
Sulfato de Potássio & 46,60 \\
Óxido de Magnésnio & 24,00 \\
Citrato de Ferro & 6,06 \\
Carbonato de Zinco & 1,65 \\
Carbonato de Manganês & 0,63 \\
Carbonato de Cobre & 0,30 \\
Iodato de Potássio & 0,01 \\
Selenato de sódio & 0,1025 \\
Paramolibdato de Amônia & 0,00795 \\
Beta Silicato de Sódio & 1,45 \\
Sulfato de Potássio Cromo & 0,275 \\
Cloreto de Lítio & 0,0174 \\
Ácido Bórico & 0,0815 \\
Fluoreto de Sódio & 0,0635 \\
Carbanato de Níquel & 0,0318 \\
Vanadato de Amônia & 0,0066 \\
Sacarose & 221,026 \\
\hline \hline
\end{tabular}

Fonte: Reeves et al 1993.

\subsubsection{Preparo das dietas}

Foram preparadas 7 dietas para a realização do experimento. Cada dieta foi admitida como um tratamento. Algumas destas dietas foram contaminadas com aflatoxinas e serviram de veículo para transportar as toxinas para o organismo dos animais.

As dietas foram elaboradas a partir de uma formulação padrão, com os componentes apresentados nas Tabelas 7, 8 e 9 . Em seguida, foram adicionadas leveduras de diferentes características e componentes da parede celular das leveduras, conforme o tratamento, e amendoim isento e com contaminação (ver Quadro 3). 
As dietas designadas de contaminadas foram preparadas a partir da adição de $80 \%$ de dieta padrão e de $20 \%$ de amendoim contaminado com 1840 $\mu \mathrm{g} . \mathrm{kg}^{-1}$ de aflatoxinas, e alguma fonte de levedura para completar o volume final, de modo que após a mistura, estas dietas apresentaram uma contaminação de cerca de $400 \mu \mathrm{g}$ de aflatoxinas por $\mathrm{kg}$ de dieta.

No controle negativo, foi efetuada a adição de $20 \%$ de amendoim, isento de contaminação mais $80 \%$ de dieta padrão. Como controle positivo foi utilizado $20 \%$ de amendoim (contaminado) mais $80 \%$ de dieta padrão, sem adição de qualquer forma de levedura. Além dessas, foi elaborada uma dieta a base de caseína $(\ell 85 \%$ de proteína) que foi adotada como a dieta padrão para os animais.

\subsubsection{Composição final das dietas}

As dietas obtidas após o preparo são apresentadas no Quadro 3, onde cada dieta é apresentada com o número de denominação do tratamento a que se refere.

Quadro 3 - Tratamentos e respectivas dietas utilizadas para a realização do bioensaio.

\begin{tabular}{|c|l|}
\hline Tratamento & Composição \\
\hline $\mathrm{T} 1$ & Dieta padrão (controle) \\
\hline $\mathrm{T} 2$ & Dieta padrão $+400 \mu \mathrm{g} \cdot \mathrm{kg}^{-1}$ de aflatoxinas* (controle positivo) \\
\hline $\mathrm{T} 3$ & Dieta padrão $+400 \mu \mathrm{g} \cdot \mathrm{kg}^{-1}$ de aflatoxinas* $+0,1 \%$ de Mycosorb \\
\hline $\mathrm{T} 4$ & Dieta padrão $+400 \mu \mathrm{g} \cdot \mathrm{kg}^{-1}$ de aflatoxinas* $+0,2 \%$ de Mycosorb \\
\hline $\mathrm{T} 5$ & $\begin{array}{l}\text { Dieta padrão }+400 \mu \mathrm{g} \cdot \mathrm{kg}^{-1} \text { de aflatoxinas } \\
\text { vivas }\end{array}$ \\
\hline $\mathrm{T} 6$ & Dieta padrão $+400 \mu \mathrm{g} \cdot \mathrm{kg}^{-1}$ de aflatoxinas* leveduras desidratadas \\
\hline $\mathrm{T} 7$ & Dieta padrão $+20 \%$ de amendoim sem aflatoxinas (controle negativo) \\
\hline
\end{tabular}

* Mesmo amendoim contaminado por aflatoxinas. 


\subsubsection{Análise da viabilidade das leveduras}

Para a análise da viabilidade das leveduras foi utilizado o método de coloração por azul de metileno descrito por Pierce (1970).

As leveduras apresentavam uma viabilidade média de $80 \%$ no momento da instalação do estudo.

\subsubsection{Determinação de aflatoxinas}

A determinação de aflatoxinas foi realizada pelo método desenvolvido por Soares \& Rodrigues-Amaya (1989).

\subsubsection{Ensaio biológico}

Para a realização do experimento foram utilizados ratos machos, desmamados (Rattus norvegicus, variedades albinos, linhagem Wistar), com idade de 25 dias e pequena variação de peso entre os mesmos, não mais que 5\% dentro de cada grupo, pesando cerca de 50 gramas cada um.

Os animais foram mantidos em gaiolas individuais e divididos em 7 grupos, com 5 animais cada, num total de 35 animais, de modo que cada tratamento teve 5 repetições. A água foi fornecida "ad libitum" e dietas de 15 gramas foram fornecidas diariamente a cada animal. O ensaio teve duração de 28 dias.

\subsubsection{Parâmetros obtidos durante o bioensaio}

\subsubsection{Consumo de alimento}

Em intervalos de 2 ou 3 dias foram realizadas pesagens, do excedente de alimentação, e completado o volume necessário para o próximo intervalo. A partir das diferenças entre o fornecimento e o excedente de alimento, nos cochos de cada animal, foi determinado o parâmetro de consumo. 


\subsubsection{Ganho de peso diário}

Durante o ensaio, os animais foram pesados, utilizando-se balança semianalítica, com duas casas decimais de precisão (em gramas) a cada 2 ou 3 dias e, o ganho de peso diário foi obtido através do cálculo do ganho de peso, em intervalos de 2 ou 3 dias, em relação ao número de dias entre as duas pesagens.

\subsubsection{Ganho de peso total}

O ganho de peso total de cada animal foi obtido pelo cálculo da diferença de peso do animal ao final do experimento, subtraído do peso inicial do mesmo, a partir do recebimento das dietas.

\subsubsection{Abate dos animais}

No vigésimo oitavo dia, após jejum de 12 horas, todos os animais foram sacrificados. Para sacrificar os animais, esses foram colocados em câmara fechada com uma atmosfera saturada de éter etílico.

\subsubsection{Peso de órgãos internos}

Decorrido o abate, a cavidade abdominal de cada animal foi aberta e, seus órgãos internos (coração, rins e fígado) foram retirados e as membranas e tecidos adiposos que os acompanhavam foram extraídos, pesados em balança analítica, registrados seus respectivos pesos e fixados para o estudo histológico.

\subsubsection{Técnicas histológicas}

As análises histológicas foram realizadas conforme descrito no Compêndio Básico de Técnicas Histológicas (Pacheco, 1981). 


\subsubsection{Observação ao microscópio ótico}

Após o preparo das lâminas, estas foram observadas ao microscópio de luz, em aumento de 16 x 1,25 x 10; e os detalhes observados em aumento de 40 x 1,25 x 10 . Além disso, nestes aumentos foram realizadas fotomicrografias das células hepáticas em todos os tratamentos.

\subsubsection{Análise estatística}

O delineamento experimental foi um arranjo inteiramente casualizado, compreendendo 7 tratamentos, com 5 repetições cada.

Tabela 10 - Esquema da análise da variância utilizado no estudo

\begin{tabular}{ll}
\hline Causas de variação & Gl \\
\hline \hline Tratamentos & 6 \\
Resíduo & 28 \\
\hline Total & 34
\end{tabular}

Os resultados obtidos foram submetidos ao teste de análise das variâncias (ANOVA) e ao Teste de Comparação de Médias de Tukey, ao nível < 0,05 de probabilidade. Para o desenvolvimento de cálculos foi utilizado o programa SAS (Statistical Analysis System) desenvolvido pelo SAS Institute Inc.

\subsection{Resultados e Discussão}

\subsubsection{Consumo de alimentos e Ganho de peso}

O consumo médio de alimentos foi maior no tratamento T5 do que T2 e o T1, contudo, não diferiu estatisticamente do T3, T4, T6 e T7 (Tabela 11). Houve maior consumo, por rato, dos animais da dieta T5 quando comparado com aqueles que receberam a dieta 2, o que pode ser explicado pelo fato de que quando o animal ingere 
alimentos contaminados por aflatoxinas há um estímulo negativo provocado por esse componente para que haja diminuação do apetite. Este fato está de acordo Stevens et al. (1960) citado por Fonseca (1984), que relatou os sintomas apresentados pelos animais que ingerem alimentos contendo aflatoxinas, sendo um deles a redução no consumo de alimento. Para justificar o maior consumo médio dos animais do T5, em relação aos do grupo controle (T1), uma hipótese seria o fato da levedura se constituir em um estimulante alimentar, afirmativa esta que estaria em acordo com Bhattacharje (1970), que cita a palatabilidade como uma das qualidades da levedura.

A percentagem de ganho de peso diário (GPD) em relação ao peso inicial, foi maior no tratamento T4 quando comparado com os tratamentos T1, T2 e T7. Contudo, não diferiu estatisticamente, dos tratamentos T3, T5 e T6 (Tabela 11).

O fato do tratamentoT4 apresentar um GPD maior do que os tratamentos sem leveduras (T1, T2 e T7), não ocorreu devido a contaminação por aflatoxinas, uma vez que os controles T1 e T7 apresentaram médias de GPD semelhantes ao T2 ( controle com aflatoxinas). Deste modo, pode-se deduzir que a contaminação por aflatoxinas não afetou o GPD dos animais. Assim, estas diferenças poderiam ser atribuídas aos mananoligossacarídeos disponibilizados ao adicionar produtos provenientes da parede celular de levedura; estes poderiam ter atuado modificando a flora intestinal, seqüestrando microrganismos patogênicos e melhorando a flora benéfica do trato gastrointestinal, promovendo um melhor aproveitamento dos nutrientes contidos na dieta e melhorando a saúde dos animais. Estes fatos estariam em concordância com Spring (1998) e Dawson \& Pirvulescu (1999), que relatam serem os carboidratos capazes de melhorar a saúde e o desempenho de monogástricos; as mananas atuam como um substrato no qual aderem bactérias patogênicas e deste modo estes patógenos são seqüestrados e eliminados do trato gastrointestinal. Além disso, não diferiu do T5, que apresentava leveduras vivas, pelo fato de que estas leveduras podem ter agido como um probiótico, as quais podem ter estimulado o crescimento, pela adição de vitaminas, enzimas e outros fatores que promovem um estímulo ao crescimento e promovendo um melhor balanço da microbiota intestinal. Tais colocações estão fundamentadas nos trabalhos de Crumplen et al. (1989) e Fuller (1989), que afirmam que as leveduras vivas 
podem atuar fornecendo vitaminas, enzimas, fatores de crescimento não identificados, promovendo crescimento da microflora intestinal, com melhor balanço na microbiota intestinal e assim estimulando o crescimento.

Tabela 11 - Consumo diário de alimentos e o ganho de peso (GPD).

\begin{tabular}{ccc}
\hline \hline Tratamentos & $\begin{array}{c}\text { Média de consumo diário em } \\
\text { Gramas (MCD) }\end{array}$ & $\begin{array}{c}\text { \% de ganho de peso diário em } \\
\text { relação ao peso inicial (GPD) }\end{array}$ \\
\hline \hline T1 & $9,60 \mathrm{c}$ & $5,22 \mathrm{c}$ \\
$\mathrm{T} 2$ & $13,19 \mathrm{~b}$ & $6,85 \mathrm{bc}$ \\
$\mathrm{T} 3$ & $13,72 \mathrm{ab}$ & $8,29 \mathrm{ab}$ \\
$\mathrm{T} 4$ & $12,76 \mathrm{ab}$ & $8,69 \mathrm{a}$ \\
$\mathrm{T} 5$ & $14,50 \mathrm{a}$ & $7,38 \mathrm{ab}$ \\
$\mathrm{T} 6$ & $14,04 \mathrm{ab}$ & $8,05 \mathrm{a}$ \\
$\mathrm{T} 7$ & $13,99 \mathrm{ab}$ & $6,84 \mathrm{bc}$ \\
\hline \hline
\end{tabular}

\subsubsection{Peso relativo de órgãos internos}

Os pesos relativos dos fígados dos animais submetidos aos diferentes tratamentos avaliados não diferiram estatisticamente entre si (Tabela 12). Estes resultados indicam que os efeitos do nível de contaminação utilizado e tempo de exposição destas toxinas aos animais, não foram suficientes para provocar diferenças significativas, no peso relativo dos fígados dos indivíduos avaliados. Estes resultados não são semelhantes àqueles obtidos por Stanley et al (1993), quando verificaram que o peso relativo do fígado de frangos que receberam $5 \mathrm{mg} \cdot \mathrm{kg}^{-1}$ de aflatoxinas, durante 28 dias, foi maior do que o peso relativo deste órgão em animais que receberam dietas isentas destas toxinas, no mesmo período. Estas diferenças podem ser atribuídas a dois fatos; primeiro, as quantidades de toxinas fornecidas aos indivíduos foram diferentes, uma vez que aos frangos foi ministrada uma dose de $5 \mathrm{mg} \cdot \mathrm{kg}^{-1}$ ao passo que os ratos foram expostos a uma dose de $400 \mu \mathrm{g} \cdot \mathrm{kg}^{-1}$; um segundo aspecto, pode ser devido ao fato de que os ratos são animais resistentes às aflatoxinas, segundo Barnes e Butler 
(1964) e a diferença de susceptibilidade poderia ser muito grande entre diferentes animais.

Os tratamentos não diferiram estatisticamente quanto ao peso relativo do coração dos animais que receberam as diferentes dietas (Tabela 12). Estes resultados também não são semelhantes a aqueles obtidos por Stanley et al. (1993). De posse da informação de que na investigação conduzida por Stanley e colaboradores, a dose fornecida aos animais, era cerca de 12 vezes maior do que as ministradas nesta experiência, pode-se dizer, que a quantidade de aflatoxinas a que os ratos foram expostos, não foi suficiente para promover diferenças significativas, no peso relativo dos órgãos internos dos animais. Estas observações são coerentes, visto que o fígado, o alvo primário dos danos promovidos pelas aflatoxinas, também não produziu alterações no peso relativo dos diferentes tratamentos.

Os pesos relativos dos rins, nos indivíduos submetidos aos diferentes tratamentos não diferiram estatisticamente entre si (Tabela 12). Também estes resultados indicam que a dose de aflatoxinas ministrada aos animais não deve ter sido suficiente para promover modificações significativas nos pesos dos rins, como já acontecera com fígado e coração nestas mesmas condições.

Tabela 12 - Peso relativo dos órgãos dos animais, submetidos às dietas experimentais.

\begin{tabular}{cccc}
\hline \hline \multirow{2}{*}{ Tratamentos } & Fígado & Coração & Rins \\
\cline { 2 - 4 } & \multicolumn{3}{c}{ Gramas por 100 gramas de peso vivo } \\
\cline { 2 - 4 } T1 & $3,26 \mathrm{a}$ & $0,46 \mathrm{a}$ & $0,94 \mathrm{a}$ \\
$\mathrm{T} 2$ & $3,46 \mathrm{a}$ & $0,41 \mathrm{a}$ & $0,79 \mathrm{a}$ \\
$\mathrm{T} 3$ & $3,39 \mathrm{a}$ & $0,42 \mathrm{a}$ & $0,87 \mathrm{a}$ \\
$\mathrm{T} 4$ & $3,42 \mathrm{a}$ & $0,49 \mathrm{a}$ & $0,82 \mathrm{a}$ \\
$\mathrm{T} 5$ & $3,63 \mathrm{a}$ & $0,44 \mathrm{a}$ & $0,77 \mathrm{a}$ \\
$\mathrm{T} 6$ & $3,66 \mathrm{a}$ & $0,44 \mathrm{a}$ & $0,78 \mathrm{a}$ \\
$\mathrm{T} 7$ & $3,56 \mathrm{a}$ & $0,46 \mathrm{a}$ & $0,79 \mathrm{a}$ \\
\hline \hline
\end{tabular}




\subsubsection{Estudo histopatológico dos fígados dos animais submetidos aos diferentes tratamentos}

$\mathrm{O}$ exame histológico do fígado de indivíduos provenientes do tratamento $\mathrm{T} 1$, dieta à base de caseína e sem presença de aflatoxinas, foi adotado como um controle de referência padrão, para diagnosticar as condições histológicas do tecido hepático de animais submetidos a outros tratamentos contendo aflatoxinas.

As Figuras $2 \mathrm{a}$ e $2 \mathrm{~b}$ mostram fotomicrografias do tecido hepático dos animais pertencentes ao T1, nas quais pode ser observado que, a lâmina do tecido do fígado, não apresentam proliferação de ductos biliares, caracterizada pela presença de áreas claras, em lacunas alongadas irregulares, comuns em alterações celulares proporcionadas por aflatoxinas, envolvendo edema celular e alteração gordurosa. Entretanto, pode ser verificado um pequeno número de regiões circulares claras (vacuolização), as quais foram consideradas normais, devido ao estado físico que os animais apresentavam antes do abate, uma vez que estes estavam gordos. Estas vacuolizações, conforme Vizioli ${ }^{1}$ (2000), podem ocorrer no tecido hepático de animais obesos, uma vez que a obesidade também pode promover modificações na homeostase celular. Assim, essas poucas vacuolizações foram adotadas como o limite superior de gordura admitido para os animais que receberam dietas contendo aflatoxinas, a partir do qual considerou-se que os animais sofreram toxicidade.

As Figuras 3a e 3b demonstram o aspecto do tecido hepático de animais que receberam dieta contaminada com $400 \mu \mathrm{g} \cdot \mathrm{kg}^{-1}$ de aflatoxinas, tratamento T2. Nestas Figuras, é possível observar a presença de grande proliferação de ductos biliares, que caracterizam edema celular e/ou acúmulo de gordura; pela intensidade é provável que sejam alterações gordurosas, com sinais de toxidez irreversível, que poderia levar à morte celular, efeitos esses provenientes de alterações celulares promovidas pelas aflatoxinas e também permite observar áreas claras circulares, vacuolizações típicas, que podem ser promovidas por alterações provenientes da toxicidade das aflatoxinas. O ocorrido está em acordo com Robbins et al (1986), que citam que embora as

\footnotetext{
${ }^{1}$ Vizioli, M.R. Comunicação pessoal, maio de 2000.
} 
alterações gordurosas sejam reversíveis, podem promover lesões irreversíveis e levar à morte celular. Além disso, citam que sob microscopia de luz estas alterações aparecem na lâmina do tecido como vacúolos pequenos ou grandes, na forma de lacunas claras.

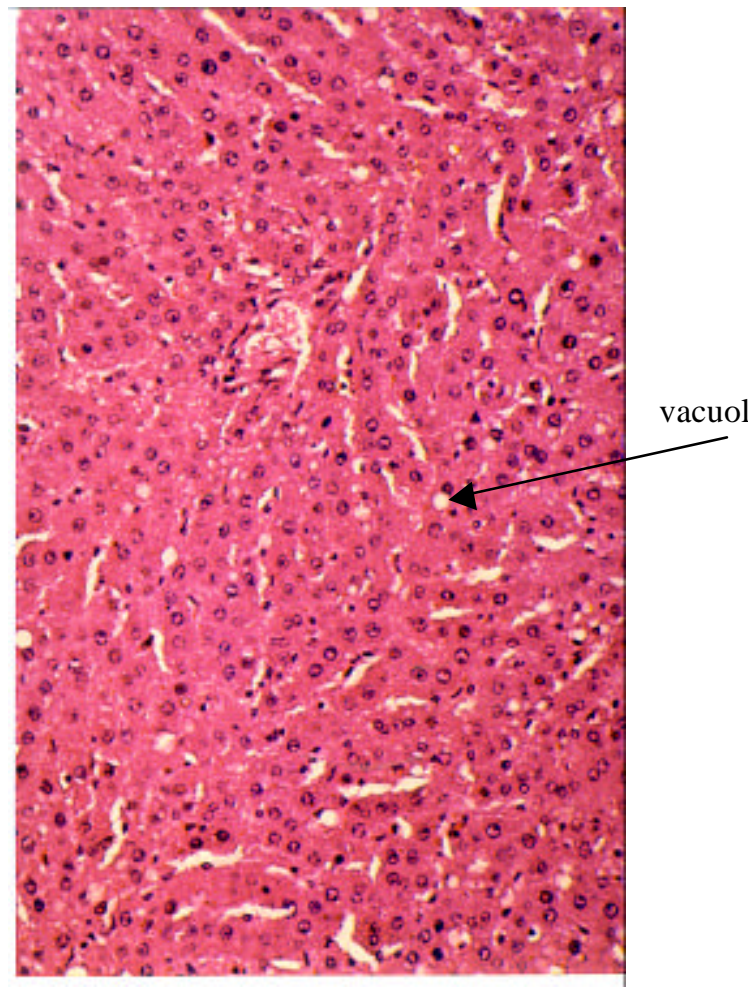

Figura 2a - Fotomicrografia em aumento de $16 \times 1,5 \times 10$, do tecido hepático de ratos que receberam alimentação a base de caseína, isenta de aflatoxinas.

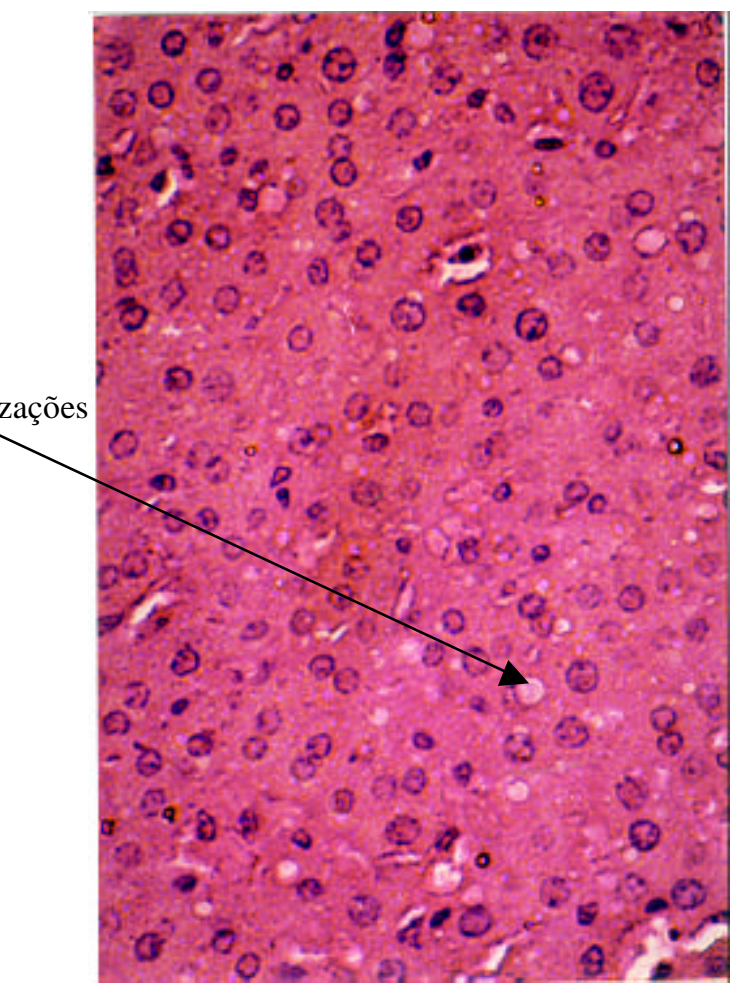

Figura $2 \mathrm{~b}$ - Fotomicrografia em aumento de 40 x 1,5 x 10 , do tecido hepático de ratos que receberam alimentação a base de caseína, isenta de aflatoxinas.

Este acúmulo de lipídios no tecido hepático vem reforçar resultados encontrados em investigações anteriores (Wogam, 1973; Rodricks \& Stoloff, 1977; Heathcote \& Hibbert, 1978; Naber \& Wallace, 1979), que atribuem este fato às alterações no metabolismo de carboidratos, promovidas pelas aflatoxinas, que 
prejudicam o transporte de lipídios, resultando em diminuição nas concentrações de glicose e acúmulo de lipídios dentro dos hepatócitos.

Analisando as Figura 4a e 4b pode ser verificado que, mesmo com a adição de $0,1 \%$ de Mycosorb $^{\circledR}$ (tratamento 3), os animais sofreram os efeitos prejudiciais das aflatoxinas, uma vez que o tecido hepático destes apresentam-se com várias vacuolizações e proliferações de ductos biliares, características de alteração celular, que pela intensidade podem representar edema celular, sinal típico de lesão reversível, mesmo assim, promovendo danos às células, com sintomas semelhantes aos observados com as lesões ocorridas nas células do tecido hepático dos animais submetidos ao T2 (Figuras 3a e 3b).

Embora este estudo não tenha sido realizado com o intuito de se verificar a capacidade do Mycosorb ${ }^{\circledR}$ em adsorver aflatoxinas, pode se deduzir que se fosse um estudo dessa natureza, os resultados obtidos seriam diferentes daqueles apresentados por Mahesh \& Devegowda (1996), quando observaram que in vitro esse produto foi capaz de se ligar a $79 \%$ das aflatoxinas presentes no meio.

Por outro lado, o melhor desempenho em ganho de peso diário, em relação ao peso inicial, quando comparado com os animais submetidos à dieta T2, com tendência de maior ganho de peso (Tabela 11), pode ser explicado através da hipótese de que, ao adicionar o Mycosorb ${ }^{\circledR}$, os mananoligossacarideos presentes nele tenham estimulado o sistema imunológico dos animais, promovendo uma melhor reação às bactérias patogênicas que se encontravam no trato gastrointestinal, impedindo que estas se aproveitassem do estado de fragilidade que seria provocado pelas aflatoxinas. Isto pode ter ocorrido, porque, conforme Dawson \& Pirvulescu (1999), mananoligossacarídeos estimulam a função imunológica do indivíduo. 


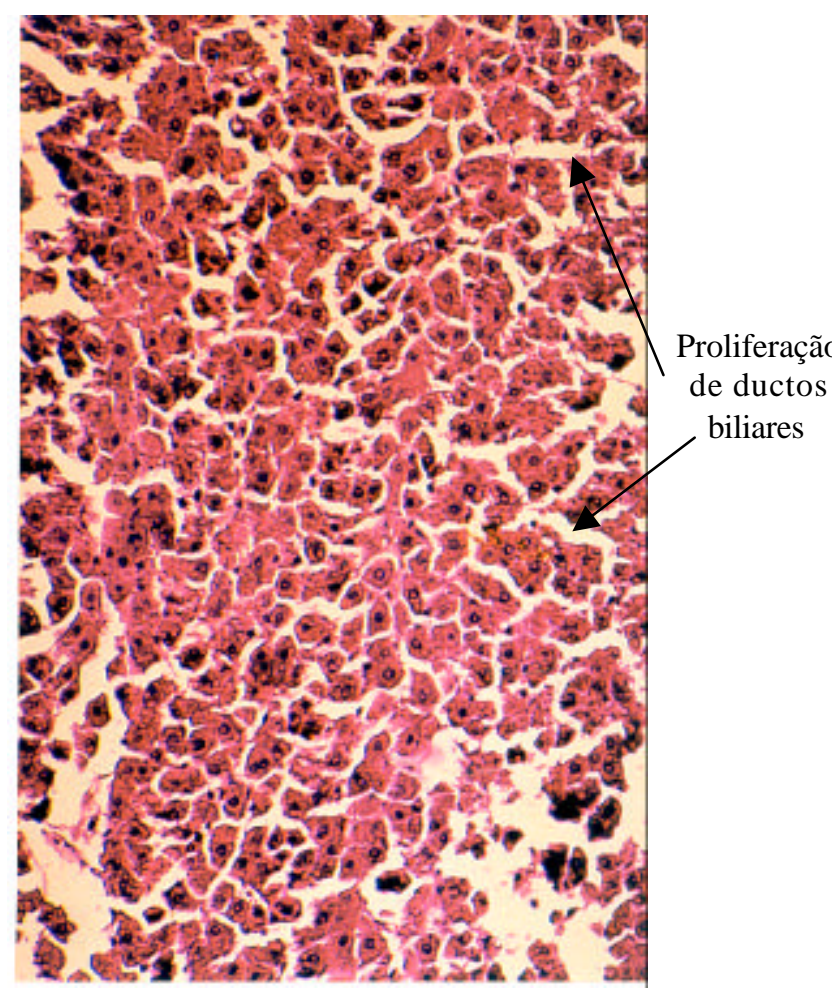

Figura 3a - Fotomicrografia em aumento de $16 \times 1,5 \times 10$ do tecido hepático de ratos que receberam alimentações contaminadas com aflatoxinas.

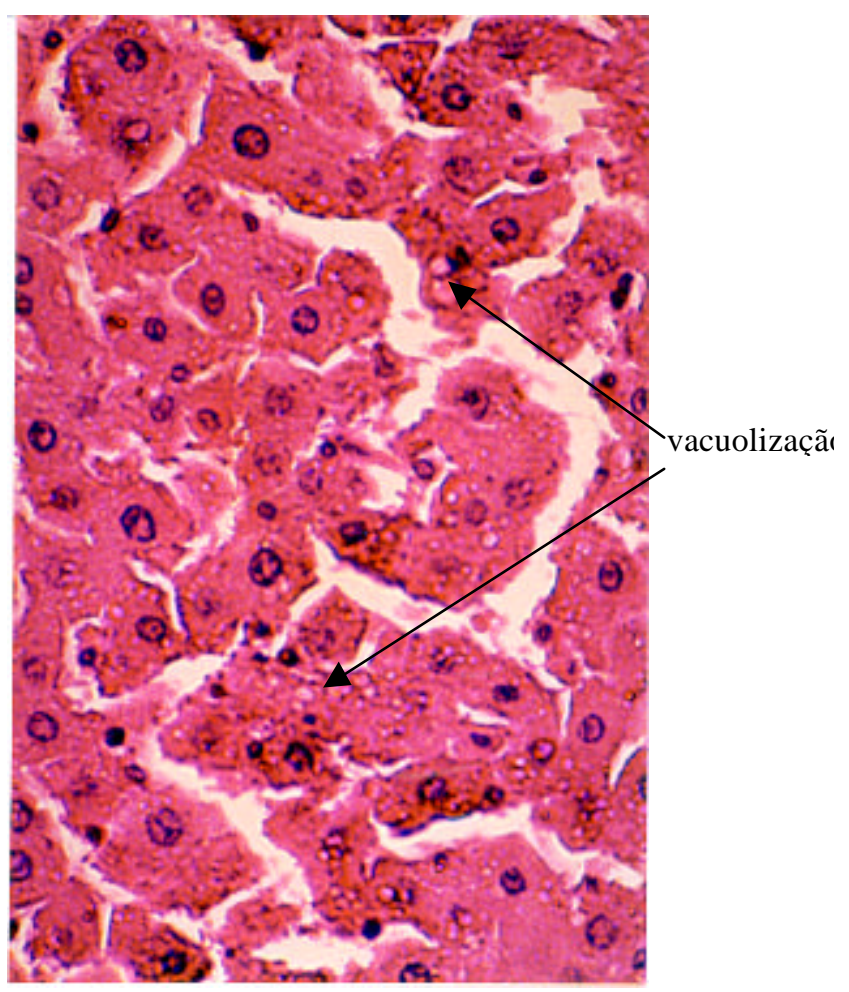

Figura $3 b$ - Fotomicrografia em aumento de $40 \times 1,5 \times 10$ do tecido hepático de ratos que receberam alimentações contaminadas com aflatoxinas.

Ao observar as Figuras 5a e 5b, pode ser verificado que os indivíduos submetidos ao tratamento 4 sofreram danos promovidos pelas aflatoxinas, uma vez que, no tecido hepático de animais daquele grupo, podem ser observados sinais de estagnação sangüínea, com degeneração de hemáceas, o que caracteriza lesão celular irreversível, com a necrose de coagulação, apresentando hialinização. Desse modo, por este quadro de toxidez, pode-se afirmar que os efeitos tóxicos encontrados, em nível histológico, em animais que receberam o $\mathrm{T} 4$, foram maiores do que os efeitos tóxicos observados em animais que receberam a dieta controle com aflatoxinas (T2).

Pela análise hepatohistológica, Figura 5 a e $5 b$, pode-se dizer que o Mycosorb ${ }^{\circledR}$ no nível de 0,2\%, não foi capaz de demonstrar habilidade em adsorver as aflatoxinas e, 
ainda pode ser que tenha potencializado a toxidez das aflatoxinas. Todavia, estes resultados não retratam as observações de Mahesh \& Devegwoda (1996), que afirmam que quando foi adicionado $0,05 \%$ de Mycosorb $^{\circledR}$, em meio contendo alimento contaminado com $200 \mu \mathrm{g} \cdot \mathrm{kg}^{-1}$ de aflatoxinas, através de investigação in vitro, foi possível observar a capacidade de se ligar com $79 \%$ das aflatoxinas presentes no meio. Para este fato, pode-se levantar duas hipóteses, a primeira, que a dose de 0,2\%, ao contrário de $0,05 \%$, possa ter efeitos tóxicos aos animais, embora seja a recomendação. A segunda hipótese seria que o estudo conduzido "in vitro" pode não ser muito próximo dos resultados obtidos "in vivo" para verificar a capacidade de reduzir a disponibilidade das aflatoxinas.

Por outro lado, os animais submetidos ao tratamento 4 obtiveram um ganho de peso de 26,8\% em relação à percentagem de ganho de peso diário sobre o peso inicial quando comparado com os animais que foram submetidos ao tratamento 2 (Tabela 11). Estes resultados mais uma vez reforçam a hipótese de que os mananoligossacarídeos atuam como estimulantes de ganho de peso, ao invés de seqüestrantes de aflatoxinas no trato gastrointestinal, uma vez que estes são semelhantes aos resultados obtidos por Stanley et al (1996) quando observaram, com a adição de 0,05\% de Mycosorb ${ }^{\circledR}$, em dieta de aves, contendo $5 \mathrm{mg} \cdot \mathrm{kg}^{-1}$ de aflatoxinas, durante 3 semanas, um ganho de peso $16 \%$ maior em relação ao peso médio do grupo controle com aflatoxinas. Como explicação para esses fatos, estão os efeitos contrários dos mananoligossacarídeos sobre a microflora patogênica no trato gastrointestinal,pois estas 


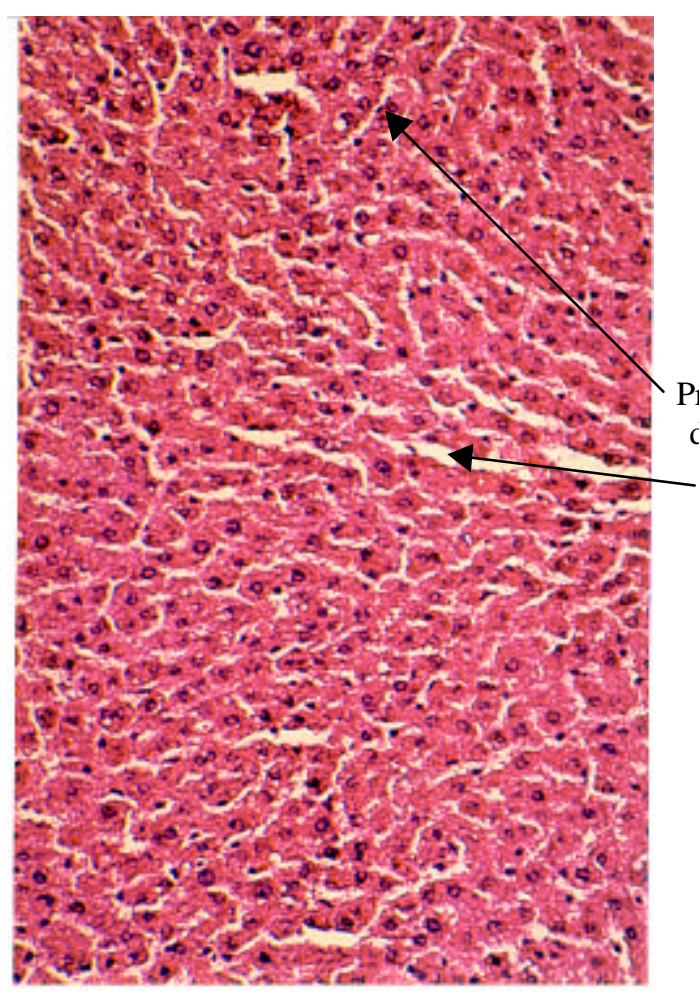

Figura 4a - Fotomicrografia, em aumento de $16 \times 1,5 \times 10$, do tecido hepático de ratos que receberam alimentação contaminada com aflatoxinas $+0,1 \%$ de Mycosorb ${ }^{\circledR}$.

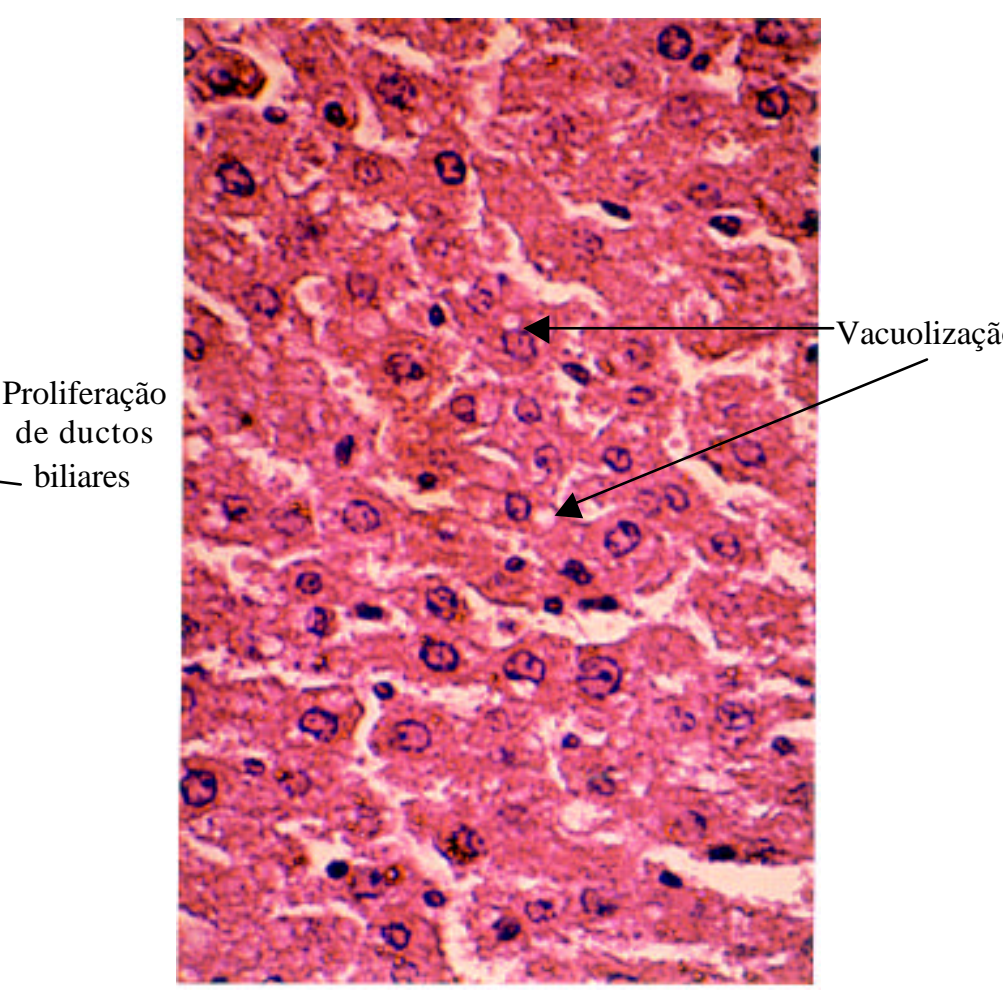

Figura $4 \mathrm{~b}$ - Fotomicrografia, em aumento de $40 \times 1,5 \times 10$, do tecido hepático de ratos que receberam alimentação contaminada com aflatoxinas $+0,1 \%$ de Mycosorb ${ }^{\circledR}$.

bactérias se aproveitam dos prejuízos promovidos por aflatoxinas às células e o sistema humoral (Rodricks \& Stoloff, 1977; Cysewski et al., 1978; Miller et al., 1978; Bouton et al., 1980; Thurston et al., 1980; Harvey et al., 1988), uma vez que, mesmo baixa concentração de aflatoxinas pode diminuir a resistência de animais à bactérias patogênicas (Píer \& Heddleston, 1970; Richard et al., 1975; Cysewski et al., 1978; Miller et al., 1978; Joens et al., 1981).

Nesta situação contraditória, onde o grupo de animais que sofreu mais drasticamente os efeitos tóxicos, em nível histológico, foi aquele que atingiu maior ganho de peso diário em relação ao peso inicial; uma possível explicação seria o fato de que o período de tempo da investigação foi relativamente curto e os danos sofridos no fígado não chegaram a afetar o ganho de peso. Segundo Barnes \& Butler (1964), os 
ratos parecem ser resistentes às aflatoxinas, e são capazes de sobreviver por um curto período experimental alimentando-se com dieta contendo altas concentrações de farelo tóxico.

Analisando as Figuras $6 \mathrm{a}$ e $6 \mathrm{~b}$ pode ser observado que o tecido hepático em animais que foram submetidos ao tratamento T5, demonstram uma leve discrepância quando comparado com aqueles submetidos ao T1, podendo até ser avaliado como sinais de toxidez leves. Assim, pela similaridade com as Figuras 2a e 2b, é possível que o tratamento com leveduras desidratadas vivas tenha sido capaz de reduzir grandemente os efeitos das aflatoxinas.

Estes resultados estão de acordo com aqueles obtidos por Stanley et al (1993), quando adicionaram $0,1 \%$ de leveduras vivas a uma dieta contendo $5 \mathrm{mg}^{-\mathrm{kg}^{-1}} \mathrm{de}$ aflatoxinas e forneceram a aves durante 28 dias e, após este período, verificaram que os animais obtiveram respostas positivas às aflatoxinas com desempenho superior ao controle com aflatoxinas.

Existem inúmeras hipóteses que tentam explicar a capacidade de células vivas de leveduras em neutralizar os efeitos aflatoxigênicos. Para Cooney (1980), é possível que a levedura S. cerevisiae suprima a severidade das aflatoxicoses através de quelação, ligando-se com as aflatoxinas, as quais são transportadas e eliminadas pelo 


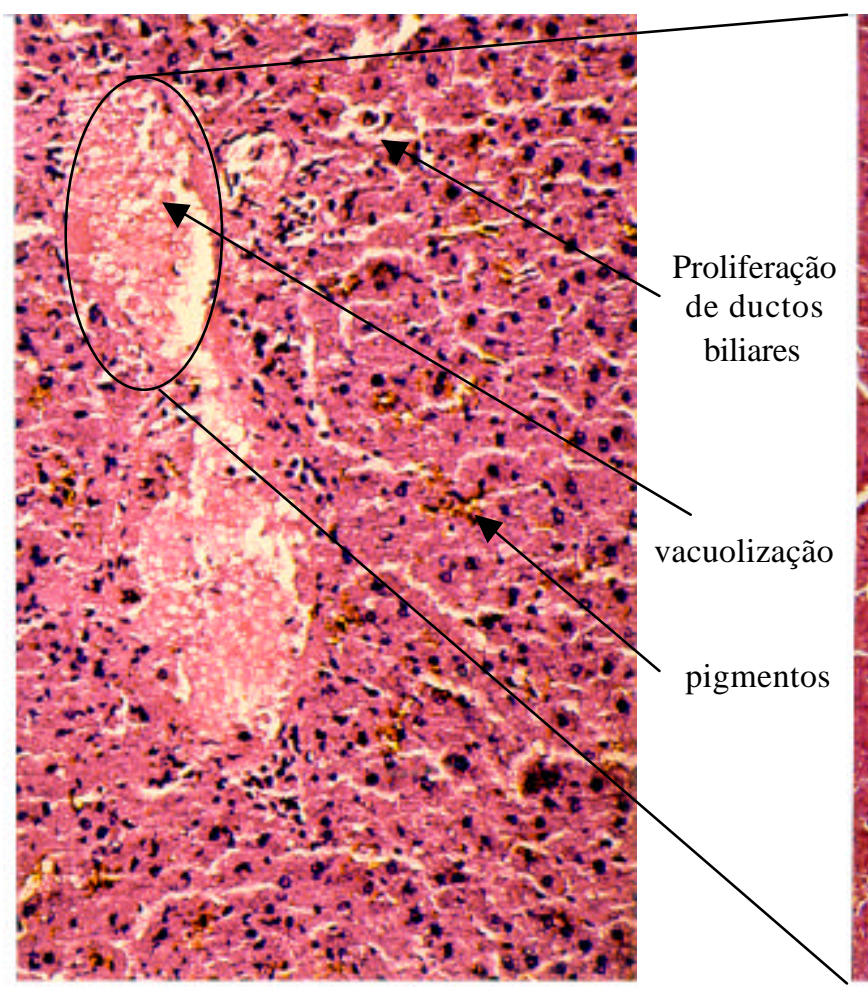

Figura 5a - Fotomicrografia, em aumento de $16 \times 1,5 \times 10$, do tecido hepático de ratos que receberam alimentação contaminada com aflatoxinas $+0,2 \%$ de Mycosorb ${ }^{\circledR}$.

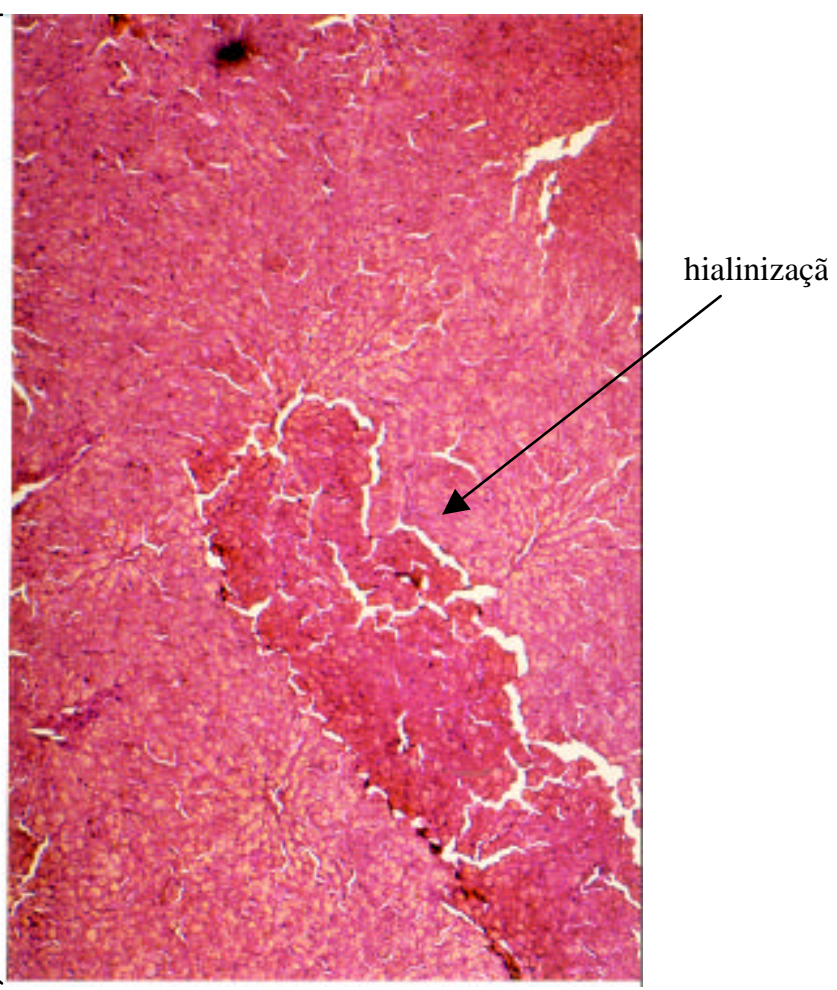

Figura 5b - Fotomicrografia, em aumento de $40 \times 1,5 \times 10$, do tecido hepático de ratos que receberam alimentação contaminada com aflatoxinas $+0,2 \%$ de Mycosorb ${ }^{\circledR}$.

trato gastrointestinal. Por outro lado, a levedura tem sido reconhecida por reduzir estresse em animais, por ser fonte de vitaminas, de um fator de crescimento não identificado, de proteínas e enzimas (Phillips e Von Tungeln, 1984; Krause et al., 1989; Crumplen et al., 1989). Esta segunda situação está de acordo com as conclusões de Sullivan et al (1978), que afirmaram que a adição de leveduras promove um incremento de enzimas que podem contribuir com a dieta modificando os efeitos das aflatoxinas. Isso vem de encontro com as observações de Mgbodile et al (1975), que citaram uma gama de enzimas biológicas, produzidas por alguns microrganismos, que possuem habilidade de descontaminar aflatoxinas. Estas observações foram reforçadas, mais 


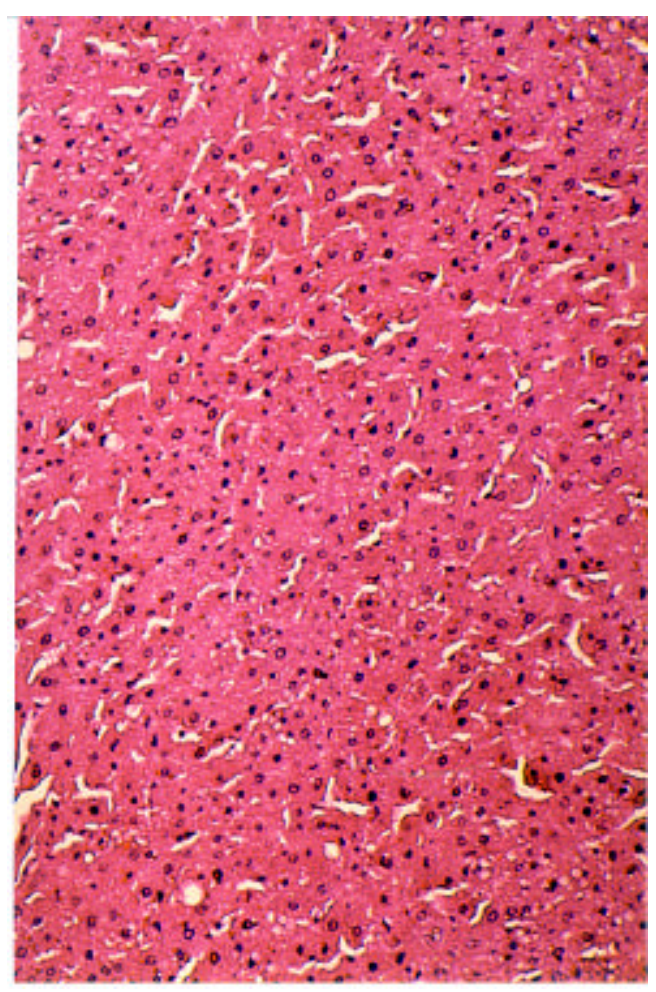

Figura 6a - Fotomicrografia, em aumento de $16 \times 1,5 \times 10$, do tecido hepático de ratos que receberam alimentação contaminada com aflatoxinas $+1,0 \%$ de leveduras desidratadas vivas.

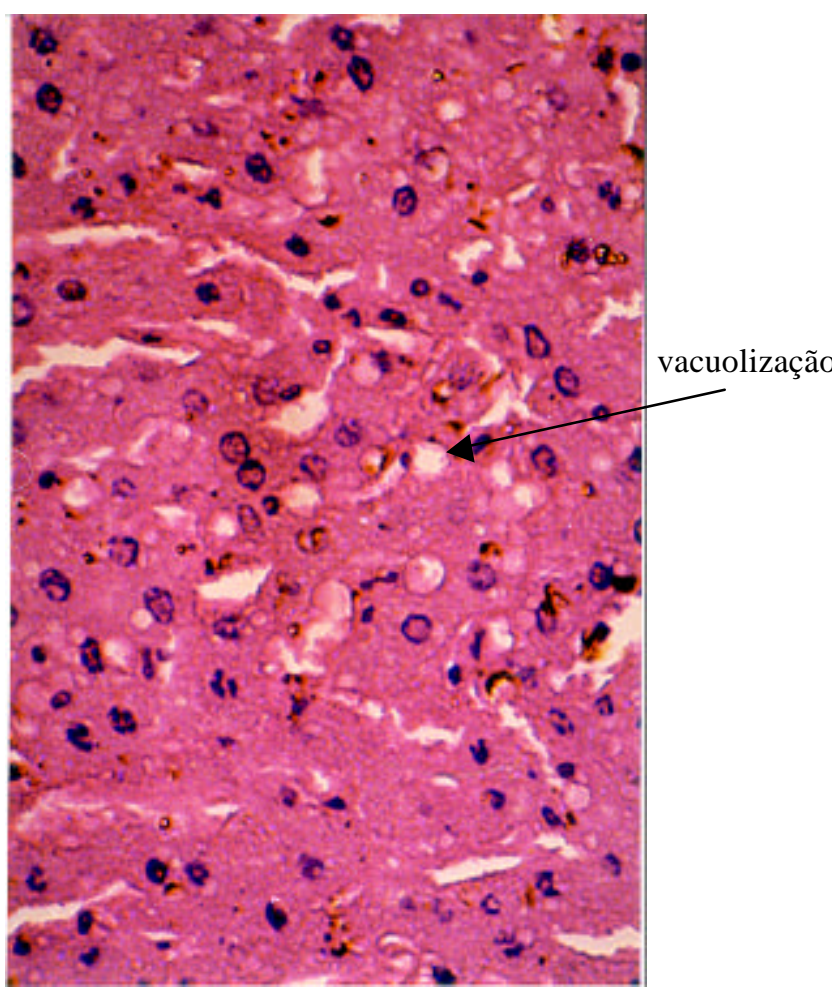

Figura $6 \mathrm{~b}$ - Fotomicrografia, em aumento de $40 \times 1,5 \quad x \quad 10$, do tecido hepático de ratos que receberam alimentação contaminada com aflatoxinas $+1,0 \%$ de leveduras desidratadas vivas.

tarde, pelo estudo de Dalvi \& McGowan (1984), que concluíram que algumas enzimas poderiam acelerar a biotransformação de certas toxinas in vivo e, assim, alterar a duração e a intensidade dos efeitos tóxicos.

Ao analisar as Figura 7a e 7b, pode ser observado que, em nível histológico, foram encontradas diversas vacuolizações e proliferações de ductos biliares, características de alterações em nível celular, que pelo conhecimento da forma como as aflatoxinas atuam, possivelmente sejam acúmulos de gorduras, com sinais de lesões não reversíveis, que poderiam levar à morte celular, de maneira semelhante com aquelas encontradas no tecido hepático de animais que foram submetidos ao tratamento 2.

Pelos resultados apresentados nas Figuras $7 \mathrm{a}$ e $7 \mathrm{~b}$, pode-se dizer que a levedura termolisada não foi capaz de controlar os danos promovidos pelas aflatoxinas. 
Entretanto, na Tabela 11, pode ser notado que esta fonte de levedura foi capaz de estimular o crescimento dos animais de maneira semelhante às demais fontes. Uma possível explicação para esta performance pode ser a presença de mananoligossacarídeos na parede celular. Segundo Rose \& Harrison (1970), dos carboidratos presentes na parede celular de leveduras (45 a 55\% do peso celular) cerca de $21 \%$ são formados por mananas. Assim, este componente presente em células de leveduras autolisadas, pode ter estimulado o sistema imunológico dos indivíduos, conforme Dawson \& Pirvulescu (1999), e, além disso, suprimindo bactérias patogênicas no trato intestinal, de acordo com Finucane et al. (1999) e Dawson \& Pirvulescu (1999) lembrando que as mananas atuam como um substrato ao qual aderem patógenos, cuja ação seqüestrante elimina estas bactérias (Dawson \& Pirvulescu, 1999). Desta forma, os animais sofreram menos com os efeitos promovidos pelas aflatoxinas, possivelmente porque estas afetam negativamente o sistema imunológico e, por isso, obtiveram melhor desempenho.

As Figuras 8a e 8b demonstram o aspecto do tecido do fígado de um animal alimentado com dieta contendo $20 \%$ de amendoim isento de contaminação por aflatoxinas e sem ser submetido à extração de seu óleo, tratamento 7. Ao observar o tecido hepático apresentado nas Figuras $8 \mathrm{a}$ e $8 \mathrm{~b}$, pode ser verificado que é semelhante ao tecido apresentado nas Figuras $2 \mathrm{a}$ e $2 \mathrm{~b}$, de modo que se pode dizer que não apresenta sinais evidentes de toxidez. As poucas regiões claras a mais do que as Figuras $2 \mathrm{a}$ e $2 \mathrm{~b}$ que apresenta o tecido hepático de animal que recebeu o T7, indicam maior acúmulo de gordura, que pode ser atribuído ao fato de que a dieta dos animais submetidos ao $\mathrm{T} 7$ receberam apresentava maior teor de lipídios e isso pode ter 


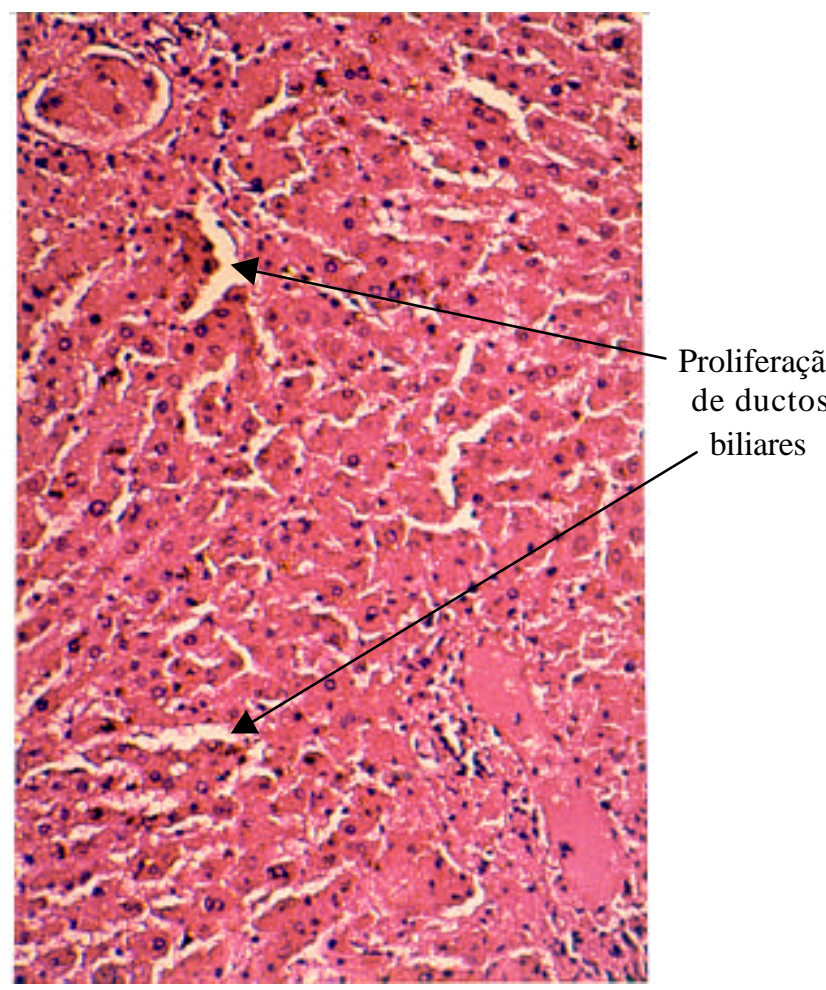

Figura 7a - Fotomicrografia, em aumento de $40 \times 1,5 \times 10$, do tecido hepático de ratos que receberam alimentação contaminada com aflatoxinas $+1,0 \%$ de leveduras termolisadas.

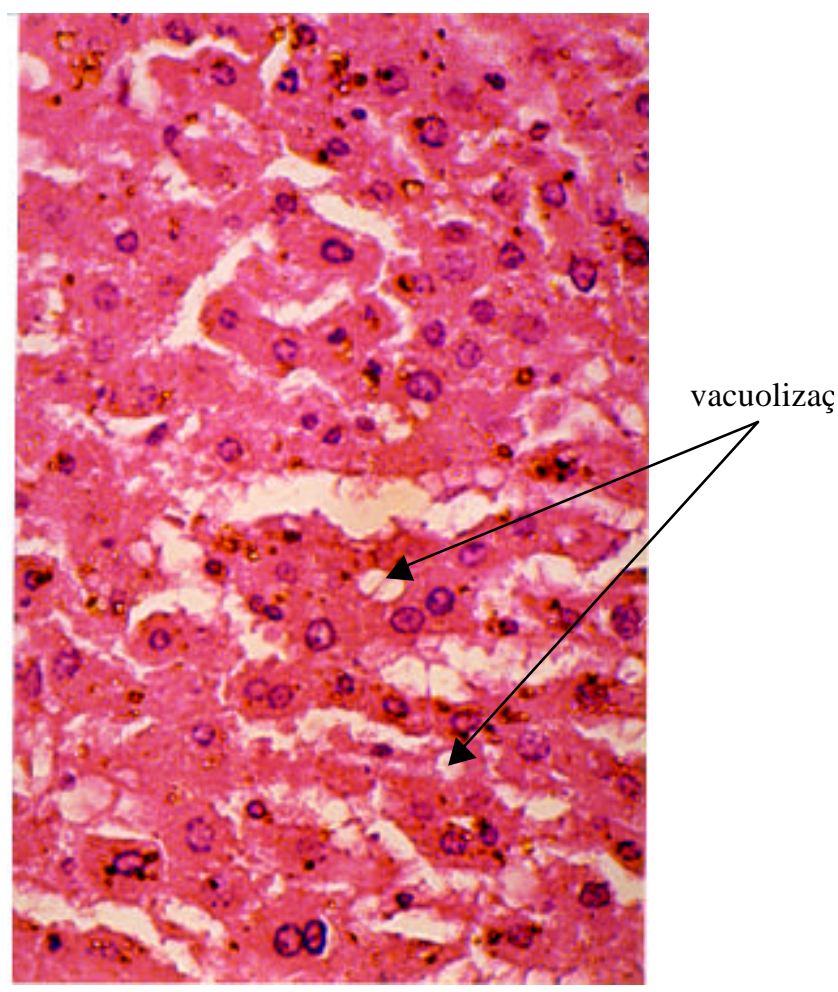

Figura $7 b$ - Fotomicrografia, em aumento de $40 \times 1,5 \times 10$, do tecido hepático de ratos que receberam alimentação contaminada com aflatoxinas $+1,0 \%$ de leveduras termolisadas.

proporcionado um acúmulo, um pouco maior, do que o do tecido hepático dos animais que receberam a dieta 1 .

Portanto, pela aparência, em nível histológico, apresentada no tecido do fígado, de animais submetidos ao T7, pode-se dizer que este tratamento também poderia ser adotado como padrão de referência, a fim de se verificar a toxidez dos demais tratamentos. 


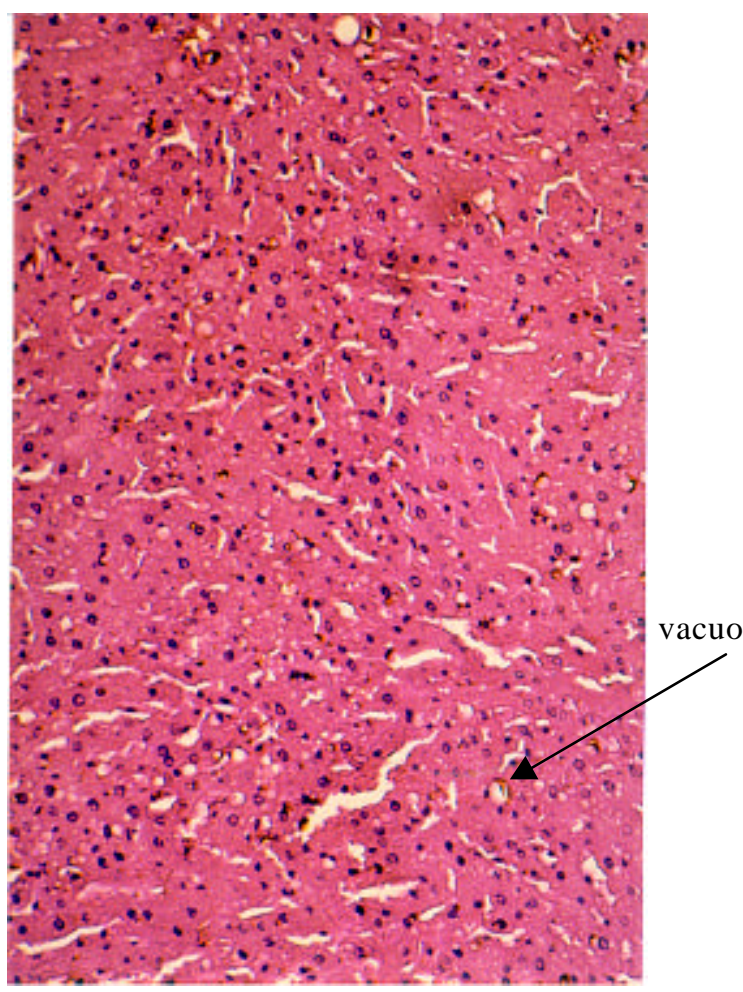

Figura 8a - Fotomicrografia, em aumento de $16 \times 1,5 \times 10$, do tecido hepático de ratos que receberam alimentação contendo $20 \%$ de amendoim, isento de contaminação por aflatoxinas.

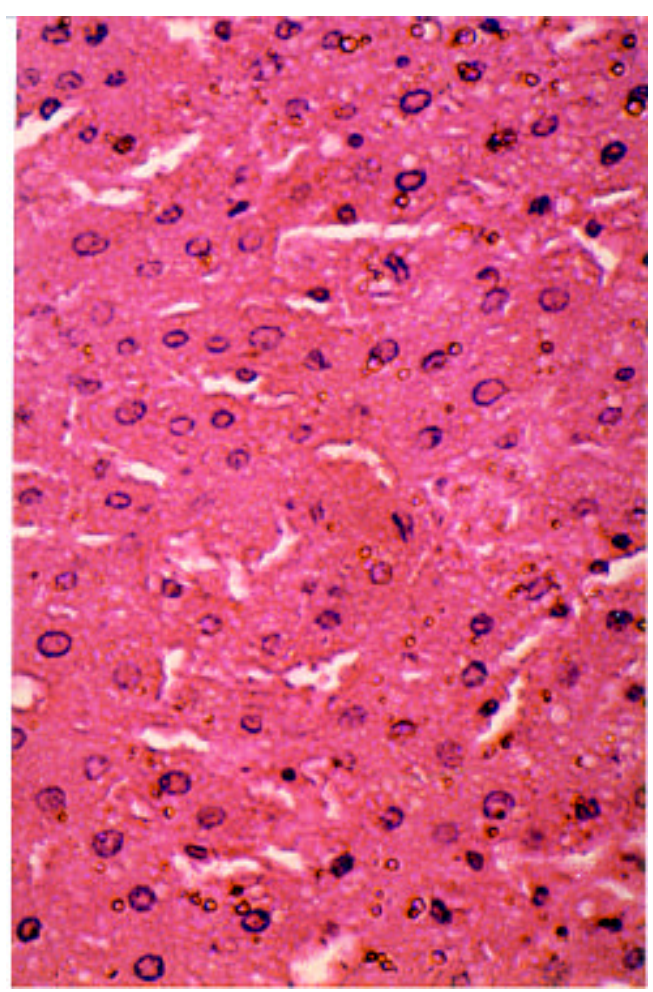

Figura $8 \mathrm{~b}$ - Fotomicrografia, em aumento de $40 \times 1,5 \times 10$, do tecido hepático de ratos que receberam alimentação contendo $20 \%$ de amendoim, isento de contaminação por aflatoxinas.

\subsection{Conclusões}

1 Os tratamentos à base de parede celular de leveduras e leveduras termolisadas não são capazes de reduzir os danos promovidos por aflatoxinas em nível histológico;

2 As leveduras desidratadas vivas são capazes de reduzir a hepatoxicidez provocada por aflatoxinas. 


\section{CONCLUSÕES}

1 A inoculação de leveduras em grãos de milho armazenados, visando a sua utilização como probiótico, é uma técnica viável.

2 A concentração de células aplicadas nos grãos de milho para armazenamento não influencia na viabilidade das células de leveduras durante o armazenamento;

3 A umidade do substrato no momento em que é realizada a inoculação das leveduras interfere na capacidade das células quanto a permanecerem viáveis durante o armazenamento, de modo que, substratos com teores de umidade elevados tendem a promover maior mortalidade das células durante $\mathrm{o}$ armazenamento;

4 A viabilidade celular das leveduras permanece constante durante por 30 dias de armazenamento; após 90 dias de estocagem há redução no número de células viáveis da ordem de $30 \%$.

5 As leveduras apresentam viabilidade celular até 110 dias de armazenamento em grãos de milho; não necessita, portanto, de aplicação imediata como poderia se esperar para um probiótico;

6 Os tratamentos à base de parede celular de leveduras e leveduras termolisadas não são capazes de reduzir os danos promovidos por aflatoxinas em nível histológico;

7 As leveduras desidratadas vivas são capazes de reduzir a hepatoxicidez provocada por aflatoxinas. 


\section{REFERÊNCIAS BIBLIOGRÁFICAS}

AGATE, A.D.; BHAT, J.V. Role of pectinolytic yeasts in degradation of mucilage layer of coffea robusta cherries. Applied Microbiology, v.14, n.2, p.256-260, 1966.

ALCARDE, A. R. Efeito da trealose na manutenção da viabilidade de células de leveduras desidratadas pelo processo de liofilização. Piracicaba, 1996. 92p. Dissertação (Mestrado) - Escola Superior de Agricultura "Luiz de Queiroz", Universidade de São Paulo.

ANGIER, N. A stupid cell with all the answers. Discover, november, p.71-83, 1986.

ARGUELLES, J.C. Heat-shock response in a yeast tps1 mutant deficient in trehalose synthesis. FEBS Letters, v.350, n.2/3, p.266-70, 1994.

BAPTISTA, A.S.; AGUIAR, C.L.; HORII, J. Comportamento da viabilidade celular de leveduras aplicadas sobre milho armazenado. In: ENCONTRO CIENTÍFICO DOS PÓS-GRADUANDOS DO CENA/USP, 5., Piracicaba, 1999. Resumos. Piracicaba:APG/CENA, 1999. p.75.

BARNES, J. M. ; BUTLER, W. H. Carcinogenisis activity of aflatoxin in rats. Nature, v.202, n.493, p.1016, 1964.

BARNETT, J.A.; PAYNE, R.W.; YARROW, D. Yeasts: characteristcs and identification. Cambridge: Cambridge University Press, 1990. 1002p.

BARTON, J.K.; HOLLANDER, J.A.D.; HOPFIELD, J.J.; et al. ${ }^{13}$ C Nuclear magnetic resonance study of trehalose mobilization in yeast spores. Journal of Bacteriology, v.151, n.1, p.177-185, 1982.

BERTO, D.A. Levedura seca de destilaria de álcool de cana-de-açúcar (Saccharomyces spp) na alimentação de leitões em recria. Piracicaba, 1985, 133p. (Dissertação de Mestrado) - Escola Superior de Agricultura "Luiz de Queiroz", Universidade de São Paulo. 
BEUDEKER, R. Developments in barker's yeast production. In: VERACHETERL, H. e DE MOT, R. Yeast:biotechnology and biocatalysis. New York: Marcel Dekker Inc., 1990. p.103-146.

BHATTACHARJE, J.K. Microorganism as potential sources of food. Advances Applied Microbiology, v.13, p.139-161, 1970.

BLOKSMA, N.; DE HEER, E.; VAN DIJK, H.; et al. Adjuvancy of lactobacilli. I. Differential effects of viable and killed bacteria. Clinical and Experimental Immunology, v.37, n.2, p.367-375, 1979.

BOSSIER, P.; FERNANDES, L.; MORGADO, C.; et al. The molecular genetics of thermotolerance in yeast. Mededelingen Faculteit Landbouwkundige en Toegepaste Biologishe Wetenschappen Universteit Gent, v.58, n.4b, p.1911-9, 1993. /Resumo em AGRIS Abstracts on CD-ROM, v.6, 1993-95/.

BOUTON, S.L.; DICK, J.W.; HUGHES, B.L. Effects of dietary aflatoxin inammoniainactivated aflatoxin on Newcastle disease antibody titers in layer-breeders. Avian Diseases, v.26, n.1, p.1-5, 1980.

BRADBURN, N.; COKER, R.D. Aflatoxin contamination in maize. Tropical Science, v.33, n.44, p.418-428, 1993.

BRASIL. Ministério da Saúde. Comissão Nacional de Normas e Padrões para Alimentos. Resolução № 34.176 publicada no Diário Oficial da União de 19 de janeiro de 1977. In: ASSOCIAÇÃO BRASILEIRA DAS INDÚSTRIAS DE ALIMENTAÇÃO. Compêndio da legislação de alimentos. São Paulo:ABIA, 1991. v.1A.

BRASIL. Leis, decretos, etc. Ministério da Agricultura. Portaria n.183, de 21 de março de 1996. Diário Oficial da União, Brasília, 25 de março de 1996. Art.1. Adotar Regulamento Técnico MERCOSUL sobre Limites Máximos de Aflatoxinas Admissíveis no Leite, Amendoim e Milho, aprovado pela Resolução do Grupo Mercado Comum do Sul n.56/94, de 01 de janeiro de 1996.

BRASIL. Ministério da Agricultura e Reforma Agrária. Regras para análise de semente. Brasília, 1992. 365p.

BUTOLO, J. E. Uso de biomassa de levedura em alimentação animal: propriedades, custo relativo e outras fontes de nutrientes. In: WORKSHOP SOBRE PRODUÇÃO DE BIOMASSA DE LEVEDURA: UTILIZAÇÃO EM ALIMENTAÇÃO HUMANA E ANIMAL, Campinas, 1996. Workshop. Campinas:Ital, 1996. p.7089. 
BUTOLO, J. E. Uso da levedura desidratada na alimentação de aves. In: SIMPÓSIO SOBRE TECNOLOGIA DA PRODUÇÃO DE LEVEDURA DESIDRATADA NA ALIMENTAÇÃO ANIMAL, Campinas, 1997. Anais. Campinas:CBNA, 1997 Campinas, 1997. p.51-83.

CARNAGHAN, R.B.; HARTLEY, R.D.; OKELLY, J. Toxicity of fluorescence properties of the aflatoxins. Nature, v.200, n.491, p.1101, 1963.

CARPENTER, J.F.; CROWE, L.M.; CROWE, J.H. Stabilization of phosphofructokinase with sugars during freeze-drying-characterization of enhanced protection in the presence of divalent-cations. Biochimica et Biophysica Acta, v.923, n.1, p.109-115, 1987

CEREDA, M. P.; ANTONANGELO, A.T.F.; GOMES, M.A.FV.; et al. Seleção de leveduras a partir de caldo de sorgo sacarino (Sorghum bicolor, L.) em fermentação natural. Revista de Microbiologia, v.20, n.1, p.78-84, 1989.

CHRISTENSEN, C.M.; KAUFMANN, H.H. Grains storage - the role of fungi in quality loss. Minneapolis:University of Minnesota Press, 1969. 153p.

CLIFFORD, J.I.; REES, K.R. The action of aflatoxin $\mathrm{B}_{1}$ on the rat liver. Biochemistry Journal, v. 102, p. 65-75, 1967.

COONEY, D. O. Actived charcoal: antidotal and other medical uses. New York:Marcel Dekker, 1980.

COUTINHO, C.; BERNARDES, E.; FÉLIX, D.; PANEK, A.D. Trehalose as cryoprotectant for preservation of yeast strain. Journal of Biotechnology, v.7, p.23-32, 1988.

COZZOLINO, S.M.F., Valor nutricional da biomassa de Saccharomyces cerevisiae. Estudos em gerações sucessivas de ratos. São Paulo, 1982. 147p. Tese (Doutorado) -Faculdade de Ciências Farmacêuticas, Universidade de São Paulo.

CROWE, L.M.; MOURADIAN, R.; CROWE, J.H.; et al. Effect of carbohydrates on membrane stability at low water activities. Biochimica et Biophysica Acta, v.769, p.141-50, 1984.

CROWE, J.H.; CARPENTER, J.F.; CROWE, L.M. The role of vitrification in anhydrobiosis. Annual Review of Physiology, v.60, p.73-103, 1998

CRUMPLEN, R.; D'AMORE, T.; PANCHAL, C.J.; et al. Industrial uses of yeast: present and future. Yeast, v.5 (special issue), p.3-9, 1989. 
CYSEWSKI, S.J.; WOOD, R.L.; PIER, A.C.; et al. Effects of aflatoxin on teh development of acquired immunty to Swine erypselas. American Journal of Veterinary Research, v.39, n.3, p.445-448, 1978.

DALALY, B.K.; TAWFEEL, M.S. Studies on low activity of baker's dry yeast stress upon storage. Iraqi Journal of Agricultural Sciences, v.5, n.1, p.125-42, 1987. /Resmo em AGRIS Abstracts on CD-ROM, v.4, 1989-90/

DALVI, R.R.; McGOWAN, C. Experimental induction of chronic aflatoxicosis in chickens by purified aflatoxin $\mathrm{B}_{1}$ and its reversal by actived charcoal., phenobarbitol, and reduced glutathione. Poultry Science, v.63,n.3, p.485-491, 1984.

DAWSON, K. A. Current and futere role of yeast culture in animal production: a review of research over the last seven years. In: BIOTECHNOLOGY IN THE FEED INDUSTRY, 9., New York, 1993. Proceedings. New York:ABFI, 1993. p. 21

DAWSON, K.A.; PIRVULESCU, M. Mananoligossacarídeos derivados de leveduras como moduladores da resposta imunológica e alternativas aos promotores de crescimento antimicrobianos. In: RONDA LATINO-AMERICANA DA ALLTECH. 9., Campinas, 1999. Anais. Campinas:Altech, 1999. p.33-41.

DESMONTS, R. Utilização do levedo na alimentação da criança. Pediatria Prática, v.39, n.7, p.365-376, 1968.

DESMONTS, R., Tecnologia da produção dos fermentos secos de destilaria. Boletim Informativo da Associação Paulista de Medicina. v. 8, n.2, p.1, 1966.

DICKENS, F.; JONES, E. H. The carcinogenic action of aflatoxin after its subcutaneous injection in the rats. British Journal Cancer, v.17, n.4, p.691-8, 1963.

DINIZ-MENDEZ, L.; BERNARDES, P.S.A.; PANEK, A.D.; et al. Preservation of frozen yeast cells by trehalose. Biotechnology and Bioengineering, v.65, n.5, 1999.

DO CARMO-SOUSA, L. Distribution of yeasts in nature. In: ROSE, A.H.; HARRISON, J.S. (Ed). The yeasts. New York: Academic Press, 1969. p79-105.

DONNINI, C.; PUGLISI, P.P; VECLI, A.; et al. Germination of Saccharomyces cerevisiae ascospores without trehalose mobilization as reveled by in vivo ${ }^{13} \mathrm{C}$ nuclear magnetic resonance spestroscopy. Journal of Bacteriology, v.170, n.8, p.3789-91, 1988.

EDDS, G. T., BORTELL, R. A.. Biological effects of aflatoxins: Poultry aflatoxin and Aspergillus flavus in corn. In: DIENER, U.L.; ASQUITZ, R.L.; DICKENS, J. W. 
(Ed.) Bulletin of the Alabama Agricultural Experiment Station. Alabama: Agricultural Experiment Station, Aubum University, 1983. p. 64-66

ELLIS, W. O.; SMITH, J.P.; SIMPSON, B.K.; et al. Aflatoxins in food: occurrence, biosynthesis, effects on organisms, detection, and methods of control. Critical Reviews in Food Science and Nutrition, v.30, n.4, p.403-439,1991.

FAO. Sampling plans for aflatoxin analysis in peanuts and corn. Roma, 1993. 75p.

FAO/ WHO/ UNU. Energy and Protein requeriments. Geneva, 1985. ( Report of the Joint FAO/ WHO/ UNU, n.724).

FARREL, J.; ROSE, A. Temperatures effect in microorganisms. Annual Review of Microbiology, v.21, p.101-20, 1967.

FERNANDES, C.F.; SHAHANI, K.M.; AMER, M.A. Therapeutic role of dietary lactobacilli and lactobacillic fermented dairy products. FEMS Microbiology Reviews, v.46, p.343-356, 1987.

FINUCANE, M. P.; SPRING, P.; NEWMAN, K.E. Incidence of mannose sensitive adhesins en enteric pathogens. In: SOUTHERN POULTRY SCIENCE,18., Atlanta, 1999. Poster. Atlanta:GA, 1999. p.21

FONSECA, H. Envenenamento alimentar - micotoxinas e micotoxicoses. In: CAMARGO, R. et al. Tecnologia dos produtos agropecuários - Alimentos. São Paulo: Nobel, 1984. cap.4, p.51-71.

FORTNUM, B.A. Effect of environment on aflatoxin development in prehavest maize. In: ZUBER, M.S.; LILLEHOJ, E.B.; RENFRO, B.L. (Ed.) Aflatoxin in maize: a proceedings of the workshop. El Batan: CIMMYT, 1986. cap.8, p.145-51.

FRISVAD, J.C.; THRANE, U. Mycotoxin production by food-borne fungi. In: SAMSON, R.A. et al. Introduction to food-borne fungi. The Netherlands: CBS, 1996. cap 4, p.251-260.

FULLER, R.E. History and development of probiotics. In: FULLER, R. (Ed.) Probiotics - the scientific basis. London: Chapman and Hall, 1992. p.1-8.

FULLER, R.E. Probiotics in man and animals. Journal Applied Bacteriology, v.66, p.365-378, 1989.

HAMILTON, P.B. Determining safe concentrations of mycotoxins. Journal Food Protection, v.47, n.7, p.570-575, 1984. 
HARVEY, R.B.; HUFF, W.E.; JUBENA, L.F.; CORRIER, D.E.; PHILLIPS, T.D. Progression of aflatoxicosis in Growing barrows. American Journal of Veterinary Research, v.49, n.4, p.482-487, 1988.

HEATHCOTE, J.G. Aflatoxins and related toxins. In: BETINA, V. (Ed) Mycotoxins, production, isolation, separation and purification. Amsterdam: Elsevier, 1984. p. 89-130.

HEATHCOTE, J.G.; HIBBERT, J.R. Aflatoxins: chemical and Biological Aspects. New York: Elsevier Science, 1978.

HORII, J. Tecnologia da produção de levedura desidratada visando a qualidade do produto final. In: SIMPÓSIO SOBRE TECNOLOGIA DA PRODUÇÃO DE LEVEDURA DESIDRATADA NA ALIMENTAÇÃO ANIMAL, Campinas, 1997. Anais. Campinas:CBNA, 1997 Campinas, 1997. p.7-25.

HOTTINGER, T.; BOLLER, T.; WIEMKEN, A. Rapid changes of heat and desiccation tolerance correlated with changes of trehalose content in Saccharomyces cerevisiae cells subjected to temperature shifts. FEBS Letters, v.220, n.1, p.112-5, 1987.

HOTTINGER, T.; SCHMUTZ, P.; WIEMKEN, A. Heat-induced accumulation and futile cycling of trehalose in Saccharomyces cerevisiae. Journal of Bacteriology, v.169, n.12, p.5518-22, 1987 b.

HOTTINGER, T.; DE VIRGILIO, C.; HALL, M.N.; et al. The role of trehalose synthesis for the acquisition of thermotolerance in yeast: II. Physiological concentrations of trehalose increase the thermal stability of proteins in vitro. European Journal of Biochemistry, v.219, n.1/2, p.187-93, 1994.

HOUNSA, C.G,; BRANDT, E.V.; THEVELEIN, J.; et al. Role of trehalose in survival of Saccharomyces cerevisiae under osmotic stress. Microbiology-UK, v.144, n.3, p 671-680,1998.

HSU, W.C. Protein form sugar on Taiwan. Sugar y Azucar, v.56, n.33, 1961.

HUFF, W.E.; KUBENA, L.F.; HARVEY, R.B.; et al. Progression of aflatoxicosis in broiler chickens. Poultry Science, v.65, n.10, p.1891-1899, 1986.

JOENS, L.A.; PIER, A.C.; CUTLIP, R.C. Effects of aflatoxin consumption on the clinical course of swine dysentery. American Journal of Veterinary Research, v.42, n.7, p. 1170-1172, 1981.

JONES, F.T.; HAGLER, W.M.; HAMILTON, P.B. Association of low concentrations of aflatoxin in feed with productivity losses in commercial broiler operations. Poultry Science, v.61, n.5, p.861-868, 1982. 
JONES, K. L.; JONES, S.E. Fermentation involved in the production of cocoa, coffee and tea. In: BUSHEL, M.E. (Ed.) Progress in industrial microbiology. Amsterdam: Elsevier Science Publisher, p.411-456, 1984.

JUNQUEIRA, L.C.; CARNEIRO, J. Métodos de Estudos. In: JUNQUEIRA, L.C.; CARNEIRO, J (Ed.) Histologia básica. Rio de Janeiro: Guanabara, 1990. cap.1, p.1-14.

KATO, I.; KOBAYASHI, S.; YOKOKURA, T.; et al. Antitumor activity of Lactobacillus casei in mice. Gann, v.72, n.4, p.517-523, 1981.

KRAUSE, O. G.; RICHARDSON, C.R.; CASTLEBERRY, R.E.; et al. Biological response of chicks fed sorghum grain based diets with added grain specif enzymes mixture and yeast. Texas Technology of Agricultural Science, v.5 n.263, p. 727735. 1989.

KUBENA, L. E.; HARVEY, R. B.; PHILLIPS, T. D.; et al. Diminution of aflatoxicosis in growing chickens by the dietary addition of a hydrated sodium calcium aluminosilicate. Poultry Science, v.69, p.727-735, 1990.

LACEY, J.; MAGAN, N. Fungi in cereal grain: their occurrence and water and temeperature relations. In: CHELKOWISKI, J. (Ed.) Cereal grain - mycotoxins, fungi and quality in drying and storage. Amsterdam: Elsevier Science, 1991. p.77-118.

LANCASTER, M. C.; JENKINS, F.P.; PHILP, J. McL. Toxicity associated with certain samples of groundnuts. Nature, v.192, n.16, p.1095-6, 1961.

LEEDLE, J. Probiotics and DFMs - mode of action in the gastrointestinal tract. In: SIMPÓSIO SOBRE ADITIVOS ALTERNATIVOS NA NUTRIÇÃO ANIMAL, Campinas, 2000. Anais. Campinas:CBNA, 2000. p.27-43.

LESLIE, S.B.; TETER, S.A.; CROWE, L. M.; el al. Trehalose lowers membrane phase transitions in dry yeast cells. Biochimica et Biophysica Acta, v.1192, n.1, p.7-13, 1994.

LESLIE, S.B.; ISRAELI, E.; LIGHTHART, B.; et al. Trehalose and sucrose protect both membranes and proteins intiact bacteria during drying. Applied and Environmental Microbiology,v.61, n.10, p.3592-3597, 1995.

LILIE, S.H.; PRINGLE, J.R. Reserve carbohydrate metabolism in Saccharomyces cerevisiae: resonses to nutrient limitation. Journal of Bacteriology, v. 143, n.6, p.1384-1394, 1980. 
LILLEHOJ, E.D. The aflatoxin in maize problem: The historical perspective. In: ZUBER, M.S.; LILLEHOJ, E.B.; RENFRO, B.L. (Ed.) Aflatoxin in maize: a proceedings of the workshop. El Batan: CIMMYT, 1986. cap.2, p.13-32.

LIMA, G.J.M.M. Uso da levedura seca (Saccharomyces cerevisiae) de destilarias de álcool de cana-de-açúcar na alimentação de matrizes suínas em gestação e lactação. Piracicaba, 1983. 139p. Dissertação (Mestrado) - Escola Superior de Agricultura "Luiz de Queiroz", Universidade de São Paulo.

MACHADO, F..P. Valor nutritivo da levedura, resíduo da produção de álcool, para vacas em lactação. São Paulo, 1983. 110p. Tese (Doutorado). Faculdade de Ciências Farmacêuticas, Universidade de São Paulo.

MACHADO, P.F. Uso da levedura desidratada na alimentação de ruminantes. In: SIMPÓSIO SOBRE TECNOLOGIA DA PRODUÇÃO DE LEVEDURA DESIDRATADA NA ALIMENTAÇÃO ANIMAL, Campinas, 1997. Anais. Campinas:CBNA, 1997. p.111-128

MAEMURA, H.; MORIMURA, S.; KIDA, K. Effects of aeration during the cultivation of pitching yeast on its characteristics during the fermentation of wort. Journal of the Institute of Brewing, v.104, n.4, p.207-211, 1998.

MAHESH, B.K.; DEVEGOWDA, G. Ability of aflatoxin binders to bind aflatoxin contaminated poultry feeds and liquid media in vitro. In: SYMPOSIUM ON BIOTECHNOLOGY IN THE FEED INDUSTRY, 12., Lexington, 1996. Annual Lexington:SBFI, 1996. p.1.1

MENTEN, J.F.M.; LIMA, G.J.M.M.; PACKER, I.U.; et d. Concentrações de uréia e ácido úrico no sangue de porcas alimentadas com ração contendo levedura seca. In: REUNIÃO ANUAL DA SOCIEDADE BRASILEIRA DE ZOOTECNIA. 21., Belo Horizonte, 1984. Anais. Belo Horizonte:SBZ, 1984. p.204.

MGBODILE, M.U.K.; HOLSCHER, M.; NEAL., R.A. Possible protective role for reduced glutathione in Aflatoxin $\mathrm{B}_{1}$ toxicity: effect of pretreatment of rats with phenobarbitol and 3-methylchoranthrene on aflatoxin toxicity. Toxicology and Applied Pharmacology, v. 34, n.1, p.128-142, 1975.

MILLER, M.W.; PHAFF, H.J.; SNYDER, H.E. On the occurrence of various species of yeast in nature. Mycophatology Mycology Applied, v.16, p.1-18, 1962.

MILLER, D.M.; STUART, B.P.; CROWELL, W.A.; et al. Aflaroxicosis in swine: its effect on immunity and relationship to Salmonellosis. American Association Veterinary Laboratory Diagnostic, v.21, p.135-146, 1978. 
MIYADA, V.S. Uso da levedura seca (Saccharomyces cerevisiae) de destilarias de álcool de cana-de-açúcar na alimentação de suínos em crescimento e acabamento. Piracicaba, 1978. 106p. Dissertação (Mestrado) - Escola Superior de Agricultura "Luiz de Queiroz", Universidade de São Paulo.

MIYADA, V.S.; LAVORENTI, A. Uso da Levedura seca (Saccharomyces cerevisiae) de destilarias de álcool de cana-de-ácúcar na alimentação de suínos em crescimento e acabamento. Revista da Sociedade Brasileira de Zootecnia, v.8, n.3, p.497-515, 1979.

MOREIRA, J.P. Uso de levedura seca (Saccharomyces cerevisiae) de destilarias de álcool de cana-de-açúcar em rações isocaloricas para suínos em crescimento e acabamento. Piracicaba, 1984. 107p. Dissertação (Mestrado) - Escola Superior de Agricultura "Luiz de Queiroz", Universidade de São Paulo.

NABER, E.C.; WALLACE, H.D. Interactions of micotoxins in animal production. Washinghton: National Academic Science, 1979. p. 3-76.

NEWBERNE, P.M. Chronic Aflatoxicosis. Journal American Veterinary Medical Association, v.163, p.1262-1269, 1973.

NICHOLS, T.E. Economic effects of aflatoxin in corn. In: DIENER, R.; ASQUITH, R.; DICKENS, J. (Ed.) Aflatoxin and Aspergillus flavus in corn. Auburn: Auburn University, 1983. p.67-71

NWAKA, S.; KOPP, M.; BURGERT, M.; et al. Is thermotolerance of yeast dependent on trehalose accumulation? FEBS Letters, v.344, n.2/3, p.225-8, 1994.

OLIVEIRA, A. C.; LIMA, E. O.; LIMA, A.W.O. Isolamento e identificação de fungos filamentosos e leveduras em frutas in natura. In: CONGRESSO BRASILEIRO DE CIÊNCIA E TECNOLOGIA DE ALIMENTOS, 17., Fortaleza, 2000. Resumos. Fortaleza:SBCTA, 2000. v.1, p.4.96.

PACHECO, A. C. Compêndio básico de técnicas histológicas. Botucatu: Universidade Estadual Paulista "Júlio de Mesquita Filho", 1981. 30p.

PANEK, A.D. Synthesis of trehalose by baker's yeast (Saccharomyces cerevisiae). Archives Biochemistry and Biophysics, v. 98, n.3, p. 348-355, 1962.

PANEK, A.D. Function of trehalose in baker's (Saccharomyces cerevisiae). Archives of Biochemistry and Biophisics, v.100, n.3, p.422-25, 1963.

PANEK, A.D. Trehalose metabolism an its role in Saccharomyces cerevisiae. Journal of Biotechnology, v.3, p.121-30, 1985. 
PANEK, A.D.; MANSURE, J.J.C.; ELEUTHERIO, C.A. The trehalose in yeast cells under stress. Criobiology, v.30, p.238-9, 1993.

PASTER, N.; DROBY, S.; CHALUTZ, E.; et al. Evaluation of the potential of the yeast Pichia guilliermondii as a biocontrol agent against Aspergillus flavus and fungi of the stored soya beans. Mycological Research, v.10, p.1201-1206, 1993.

PERDIGON, G.; ALVAREZ, S. Probiotics and the immune state. In: FULLER, R. (Ed.) Probiotics - the scientific basis. London: Chapman and Hall, 1992. p.146-180.

PETERSSON, S.; SCHNÜRER, J. Biocontrol of mold growth in higt-moisture wheat stored under airtight conditions by Pichia anomala, Pichia guilliermondii, and Saccharomyces cerevisiae. Applied and Environmental Microbiology, v.61, n.3, 1995.

PETERSSON, S.; SCHNÜRER, J. Pichia anomala as a biocontrol agent of Penicillium roqueforti in higt-moisture wheat, rye, barley, and oats stored under airtight conditions. Canadian Journal Microbiological., v.44, p.471-476, 1998.

PHILLIPS, W. A.; VON TUNGELN, K. L. Effect of adding yeast culture to the receiving ration of stressed stocker calves. Stillwater: Agricultural Experimental Station, 1984. p.117 (Animal Science reported)

PÍER, A.C.; HEDDLESTON, K.L. The effect of aflatoxin on immunity in rurkeys. I. Impairment of actively acquired resistance to bacterial challenge. Avian Disease, v.14, p.797-809, 1970.

PIERCE, J.S. Analysis committee measurement of yeast viability. Journal of the Institute of Brewing, v.76, n.5, p.442-443, 1970

PIPER, P.W. Molecular events associated with acquisition of heat tolerance by the yeast Saccharomyces cerevisiae. Fems Microbiology Reviews, v.11, n.4, p.339-356, 1993.

PUZZI, D. Abastecimento e armaze nagem de grãos. Campinas:Icea, 1986. 603p.

REEVES, P.G.; NIELSEN, F.H.; FAHEY, G.C. Ain-93 purified diets for laboratory rodents - final report of the american institute of nutrition ad hoc writing committee on the reformulation of the ain-76a rodent diet. Journal of Nutrition, v.23, n.11, p.1939-1951, 1993.

RICHARD, J.L.; THURSTON, J.R.; PIER, A.C. Micotoxin-induced alterations of immunity. In: Schlessinger, P. (Ed.). Microbiology. Washinghton: American Society Microbiologists, 1975. cap. 9, p.388-396. 
ROBBINS, S.L.; ANGELL, M.; KUMAR, V. A doença em nível celular. In: ROBBINS, S.L.; ANGELL, M.; KUMAR, V (Ed.). Patologia básica. São Paulo: Ateneu, 1986. cap. 1, p.3-31

RODRICKS, J.V.; STOLOFF, L. Aflatoxins residues from contaminated feed in edible tissues of food-producing animals. In: RODRICKS, J.V C.; HESSELTINE, W.; MEHLMAN, M.A. (Ed.) Mycotoxins in human and animal health. Park Forest South: Patholox publishers, 1977. cap.3, p.67-69.

ROEBUCH, B.D.; MAXUILENKO, Y.Y. Biochemical mechanism and biological implications of the toxicity of aflatoxins as related to aflatoxin carcinogenesis. In: EATON, D.L.; GROOPMAN, J.D. (Ed). The toxicology of aflatoxins. London: Academic Press, 1994. p.27-43.

ROSE, A.H.; HARRISON, J.N. The yeasts. London: Academic Press, 1970. v3. $590 \mathrm{p}$.

ROSINI, G.; FEDERICI, F.; MARTINI, A. Yeast flora of grape berries during ripening. Microbial Ecology, v.8, p.83-89, 1982.

SAAVEDRA, J.M.; BAUMAN, N.A.; OUNG, I.; et al. Feeding of Bifidobacterium bifidum and Streptococcus thermophilus to infants in hospital to prevention of diarrhoea and shedding of rotavirus. Lancet, v.344, p.1046-1049, 1994.

SALGADO, J. M. Levantamento de fungos toxigênicos associados a cereais e seus subprodutos através de ensaios biológicos com ratos albinos. Piracicaba, 1978. 152p. Tese (Doutorado) - Escola Superior de Agricultura "Luiz de Queiroz", Universidade de São Paulo.

SAWADA, H.; FURUSHIRO, M.; HIRAI, K.; et al. Purification and characterization of an antihypertensive compound from Lactobacillus casei. Agricultural Biological Chemistry, v.54, p.3211-3219, 1990.

SILLJE, H.H.W.; PAALMAN, J.W.G.; TER-SCHURE, E.G.; et al. Function of trehalose and glycogen in cell cycle progression and cell viability in Saccharomyces cerevisiae. Journal of Bacteriology, v.181, n.2, p.396-400, 1999.

SILVA, N.; JUNQUEIRA, V.C.A.; SILVEIRA, N.F.A. Manual de métodos de análise microbiológica de alimentos. São Paulo: Varela, 1997. 295p.

SOARES, L.M.V; RODRIGUES-AMAYA, D.B. Survey of aflatoxins, ochratoxin A, zearalenone and sterigmatocystin in some Brazilian food by using multi-toxin thinlayer chromatografic method. Journal of Official Analytical Chemists, v.72, p.226, 1989. 
SPRING, P. Mananoligossacarídeo: seu papel biológico na condição de aditivo natural de ração para suínos e aves. In: RONDA LATINO-AMERICANA DA ALLTECH. 9., Campinas, 1998. Anais. Campinas:Altech, 1998. p.57-70.

SPRING, P. Yeast's secret weapon aids animal production. In: SIMPÓSIO SOBRE ADITIVOS ALTERNATIVOS NA NUTRIÇÃO ANIMAL, Campinas, 2000. Anais. Campinas:CBNA, 2000. p.44-55.

STANLEY, V.G.; OJO, R.; WOLDESENBET, S.; HUTCHINSON, et al. The use of Saccharomyces cerevisiae to suppress the effects of aflatoxicosis in broiler chicks. Poultry Science,v.72, n.10, p.1867-1872, 1993.

STANLEY, V.G.; CHUWU, H.; GREAVES, R. Interaction of temperature, aflatoxin and mycosorb on the performance of broiler chicks. SYMPOSIUM ON BIOTECHNOLOGY IN THE FEED INDUSTRY. 12., Lexington, 1996. Annual. Lexington:SBFI, 1996. p.1.8

STARK, A. Molecular aspects of aflatoxin Bl mutagenesis and carcinogenesis. In: STEYN, P.S.; VLEGGAAR, R. (Ed.) Micotoxins and phycotoxins. Amsterdam: Elsevier Science Pub., 1986. v.1, p435-445.

STOLOFF, L. Aflatoxin: a overview. In: RODRICKS, J.V C.; HESSELTINE, W.; MEHLMAN, M.A. (Ed.) Mycotoxins in human and animal health. Park Forest South: Patholox publishers, 1977. cap.1, p.7 -28

SULLIVAN, T.W.; KUHL, Jr.; HOLDER, D.P. Evaluation of Brewer's dried grain yeast in turkey diets. Poultry Science, v. 57, n.5, p.1329-36, 1978.

SUOMALAINEN, H.; PFAFFLI, S. Changes in the carbohydrate reserves of baker's yeast during growth and standing. Journal of the Institute of Brewing, v.67, p.249-54, 1961.

SUSSMAN, A.S.; LINGAPPA, B.T. Role of trehalose in ascopores of Neurospora tetrasperma. Nature, v.130, p.1343, 1959.

SUUTARI, M.; LIUKKONEN, K.; LAAKSO,S. Temperature adaptation in yeasts: the role of fatty acids. Journal of General Microbiology, v.136, p.1469-74, 1990.

SZOPA, J.S.; ZWOSLINSKI, G.; KOWAL., K.; et al. The effect of substrate feeding on the physiological characteristics and the trehalose content in Saccharomyces cerevisiae. Polish Journal Food and Nutrition Sciences, v. 1, n.2, p.41-50, 1992. /Resumo em CAB Abstracts on CD-ROM, v.5, 1993-95/.

THERON, J.J. Acute liver injury in ducklings as a result of aflatoxin poisoning. Laboratory Investigation, v.14, n.9, p.1586-1603, 1965. 
THEVELEIN, J.M. Regulation of trehalose mobilization in fungi. Microbiological Reviews, v.48, n.1, p.42-59, 1984.

THURSTON, J.R.; COOK, W.; DRIFTMIER,K.; et al. Decreased complement and bacteriostatic activities in the sera of cattle given single or multiple doses of aflatoxin. American Journal of Veterinary Research, v.41, n.8, p.1272-1276, 1980.

TREVELYAN, W.E.; HARRISON, J.S. Studies on yeast metabolism. V. The trehalose content of baker's yeast during a anaerobic fermentation. Biochemical Journal., v.62, n.2, p.177-183, 1956.

VANANUVAT, P.; KINSELLA, J.E. Amino acid composition of protein isolates form Saccharomyces fragílís. Journal Agricultural Food Chemistry, v.23, n.3, p.595 597, 1975.

VIZIOLI, M.R. Doença em nível celular. Araras: Faculdade de Odontlogia "Fundação Hermínio Ometto", 1996.

WALKER, G.M. Magnesium as a stress-protectant for industrial strains of Saccharomyces cerevisiae. Journal of the American Society of Brewing Chemists, v.56, n.3, p.109-113, 1998.

WATSON, K.; CAVICCHIOLI, R. Acquisition of ethanol tolerance in yeast cells by heat shock. Biotechnology Letters, v.5, n.10, p.683-8, 1983.

WIENKEN, A. Trehalose in yeast, stress protection rather than reserve carbohydrate. Antonie van Leeuwenhoek, v. 58, p.209-17, 1990.

WILSON, K.; MCLEOD, B.J. The influence of conditions of growth of the endogenous metabolism of Saccharomyces cerevisiae: effect on protein, carbohydrates, sterol and fatty acid content and on viability. Antonie van Leeuwenhoek, v.42, p.397410, 1976.

WOGAM, G.N. Aflatoxin carcinogenesis. Methods Cancer Research, v.7, p.303-344, 1973. 